\title{
El Arte como Metodología de Enseñanza en la Educación formal; para fomentar: Pensamiento divergente, Gestión emocional e Identidad cultural
}

\author{
Fiorella Hinostroza Gálvez. Universidad de Granada \\ Recepción: 09.07.2018 | Aceptado: 15.09.2018 \\ Correspondencia a través de ORCID: Fiorella Hinostroza \\ iD $0000-0002-9994-7135$ \\ Citar: Hinostroza Gálvez, F. (2018). El Arte como Metodología de Enseñanza en la Educación \\ Formal, para fomentar: Pensamiento Divergente, Gestión Emocional e Identidad Cultural. \\ ReiDoCrea, 7, 202-247.
}

\begin{abstract}
Resumen: El presente trabajo indaga sobre los diversos acontecimientos y cuestionamientos sobre la evolución y desarrollo de la educación; y su correlación con los factores sociales y económicos. En primer lugar, se considera la importancia de los enfoques de enseñanza que adoptan los diversos docentes pertenecientes a diversos contextos socioculturales durante el proceso de enseñanza - aprendizaje, en la que se cuestiona la falta de coherencia entre las intenciones y estrategias utilizadas. Así mismo se discute sobre la innovación en la educación, y se plantea el uso del arte como metodología de enseñanza, con el objetivo principal de generar en los estudiantes, el desarrollo del pensamiento crítico - creativo, la gestión emocional e identidad cultural; para ello se dan conocer los diversos testimonios de artistas de diversas especialidades y contextos socioculturales. Finalmente se ofrecen una serie de recomendaciones para continuar con futuras investigaciones similares para lograr un verdadero cambio y avance en la calidad educativa de manera integral y no sólo enfocada en la obtención del mérito.
\end{abstract}

Palabras clave: Gestión Emocional | Identidad cultural

Art as a Teaching Methodology in formal Education; to encourage: Divergent thinking, Emotional management and Cultural identity

Abstract: This research explores the different events and questions about the development of education; and its correlation with social and economic factors. In first place, the importance of the teaching approaches adopted by the teachers belonging to different contexts during the teaching - learning process, in which the lack of coherence between the intentions and strategies used. Likewise, discussed about the innovation in education, specifically the use of art as a teaching methodology, with the objective of generating in students, the development of critical - creative thinking, emotional management and cultural identity; for this, the testimonies of artists from different specialties contexts are known. Finally, a series of recommendations are offered to continue with similar future research to achieve a true change and advance in the educational quality in an integral way and not only focused on obtaining a merit.

Keywords: Emotional Management | Cultural Identity

\section{Introducción}

"Me he subido sobre la mesa para recordarme a mí mismo que tenemos que modificar constantemente la perspectiva desde la que miramos el mundo. Porque el mundo es diferente visto desde aquí. ¿No me creen?. Pues levántense y vengan a comprobarlo."

(Kleinbaum, 1997, p. 80)

¿Tenemos actualmente un Sistema Educativo que se encuentra estancado?, esta pregunta nos lleva a la reflexión si realmente la educación que se imparte en los diversos ámbitos responden a las demandas socioculturales de nuestra época. A lo largo de la historia de la educación hemos visto cómo ha venido ampliando sus horizontes, puesto que en la edad antigua - período histórico que coincide con el surgimiento y desarrollo de las primeras civilizaciones- solo un grupo reducido recibía educación, considerándola como un privilegio y centrada en tópicos específicos que responden a las necesidades de cada sociedad y cultura. Los griegos, por ejemplo, se 
enfocaban en la filosofía, a los romanos les interesaba que las personas aprendan a escribir y leer - gramática y estructuras formales de la lengua-, las culturas preincas e incaicas focalizaban toda su atención en los saberes ancestrales - conocimiento de plantas medicinales, agricultura, etcétera. Todas las culturas y sociedades iban generando y adaptando el proceso de enseñanza -aprendizaje en base a sus necesidades. Con la llegada de la religión católica, especialmente a finales del siglo $\mathrm{XV}$ y durante el siglo XVI con las colonizaciones, el principal objetivo de la educación era la de evangelizar a las poblaciones.

Así, también, con la revolución industrial del siglo XIX se implementa un sistema educativo público gratuito, concebida como una obligación para el Estado y respondiendo una vez más a las necesidades del contexto, puesto que se necesitaba mano de obra calificada "educación en masas" y debido a la influencia de la época la inteligencia de una persona se centraba en dos grandes capacidades: el razonamiento deductivo y el conocimiento de la cultura clásica. Es allí donde nace el término de rendimiento académico, redireccionando nuevamente el plan de estudios en los que encabezan las matemáticas, ciencias, idiomas. El cual se convierte en las raíces de la educación que se conservan actualmente a pesar, inclusive, de estar inmersos en una globalización digital de la información (Robinson, 2011).

En general la población sabe que la educación es la institución básica que forma a los futuros ciudadanos dentro de una sociedad; su evolución pasando desde la industrialización hasta la era tecnológica, atravesando cambios ambientales, socioculturales, políticos y económicos que influyen directamente en las propuestas institucionales privadas y públicas. Cómo menciona el filósofo Walter Bryce Gallie "democracia", "justicia" y "educación" son conceptos esencialmente controversiales, tienen un significado distinto para cada persona, en función de sus valores socioculturales (citado en Robinson y Aronica, 2016). Por lo que las sociedades han venido estableciendo reformas educativas de manera irreflexiva tratando de conseguir estándares de calidad para todos.

En el Informe Education Policy Outlook emitido por la Organisation for Economic Cooperation and Development (OECD, 2015) nos da a conocer que durante estos últimos sietes años se han realizado un total de 450 reformas, de los que solo el $10 \%$ de los países afirman estar evaluando si realmente funcionan. Estos cambios que vienen siendo nada más que imposiciones de los adultos hacia los estudiantes, del gobierno hacia las instituciones educativas, desde arriba hacia abajo; sin tener en cuenta que hay una gran distancia, real y metafórica, entre los despachos donde se elaboran las leyes educativas y las aulas donde las niñas y niños aprenden (Díaz, 2017). Esta tendencia refleja una vez más que la variable con mayor influencia en el sistema educativo de un país, es su economía. En el análisis establecido en base a los resultados del PISA 2015 y el porcentaje del PIB invertido en educación de países como Finlandia, España y Perú, el Banco Mundial (2016) hace referencia al PIB del gasto total en un año determinado del Gobierno en instituciones educativas - tanto públicas como privadas - administración educativa y subsidios o transferencias para entidades privadas de un país con la accesibilidad y calidad de su sistema educativo, condicionando la implementación de nuevas reformas, programas, proyectos, remuneración a los docentes, inversión en infraestructura de los centros, etcétera.

Un claro ejemplo de esta correlación se evidencia en la Figura 1, en la que se puede ver que Finlandia desde los años 80 presenta una mayor inversión del gasto público en educación, equivalente al 5,4 \%, comparado a España que presenta un 1,8 \% y con relación a Perú — no se evidencian datos - inversión que se ha mantenido a lo largo de los años puesto que en base a la información correspondiente al 2014, véase la Figura 2, Filandia continúa presentando una mayor porcentaje equivalente al $7,2 \%$. 
Mientras que España cuenta con un 4,3 \% y Perú incrementó a un 3,8 \%; si nos basamos en la correlación de "a mayor inversión de PBI mejor accesibilidad y calidad en el sistema educativo de un país", podemos apreciar en las Figuras 3 y 4 que los resultados obtenidos de la prueba PISA del 2015, Finlandia obtiene un mejor rendimiento en todas las asignaturas y un mayor índice de accesibilidad social, superando a España y Perú (OECD, 2016).

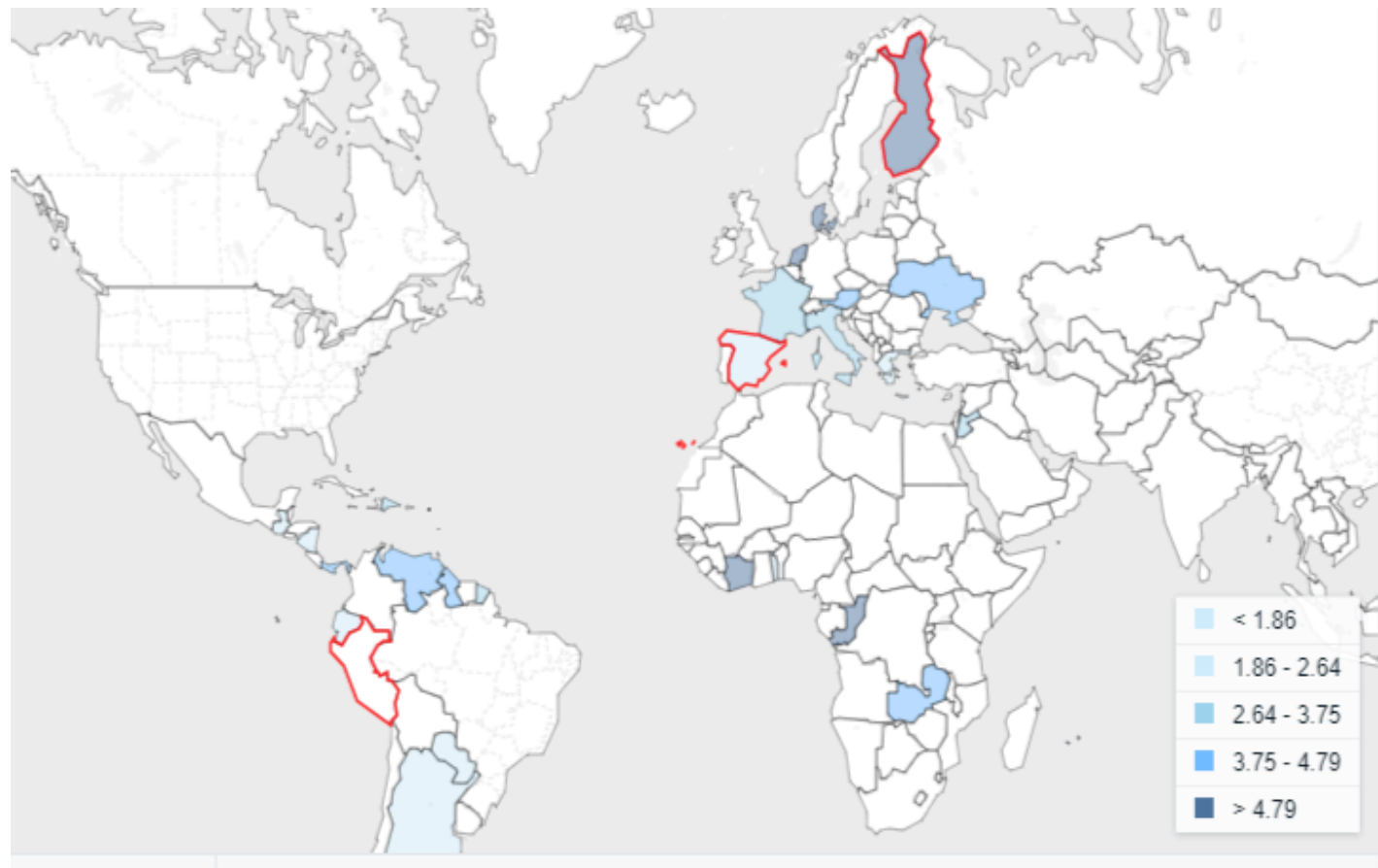

1970

Figura 1: Gasto Público en Educación en 1970, Banco Mundial (2016).

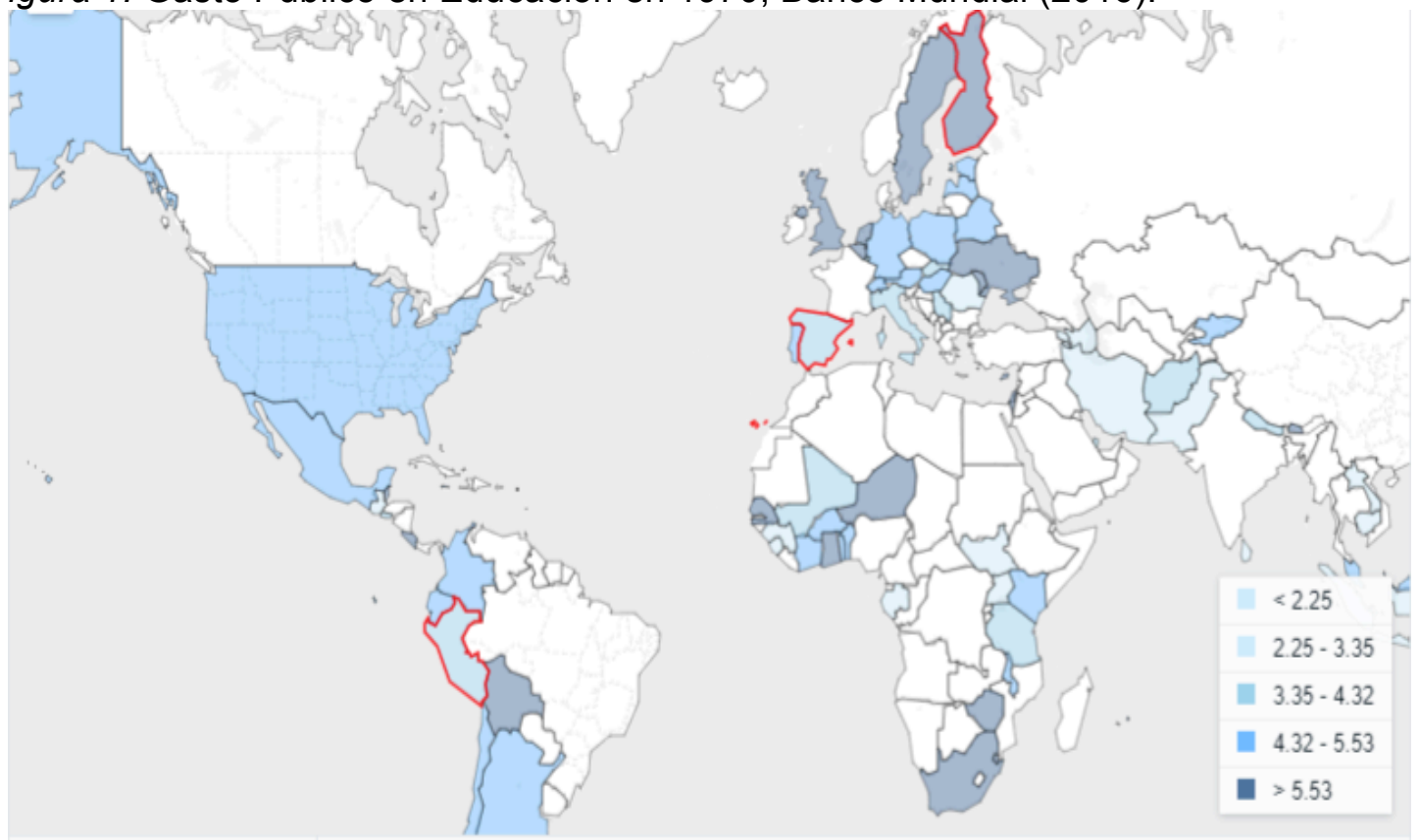

2014

Figura 2: Gasto Público en Educación en 2014, Banco Mundial (2016). 


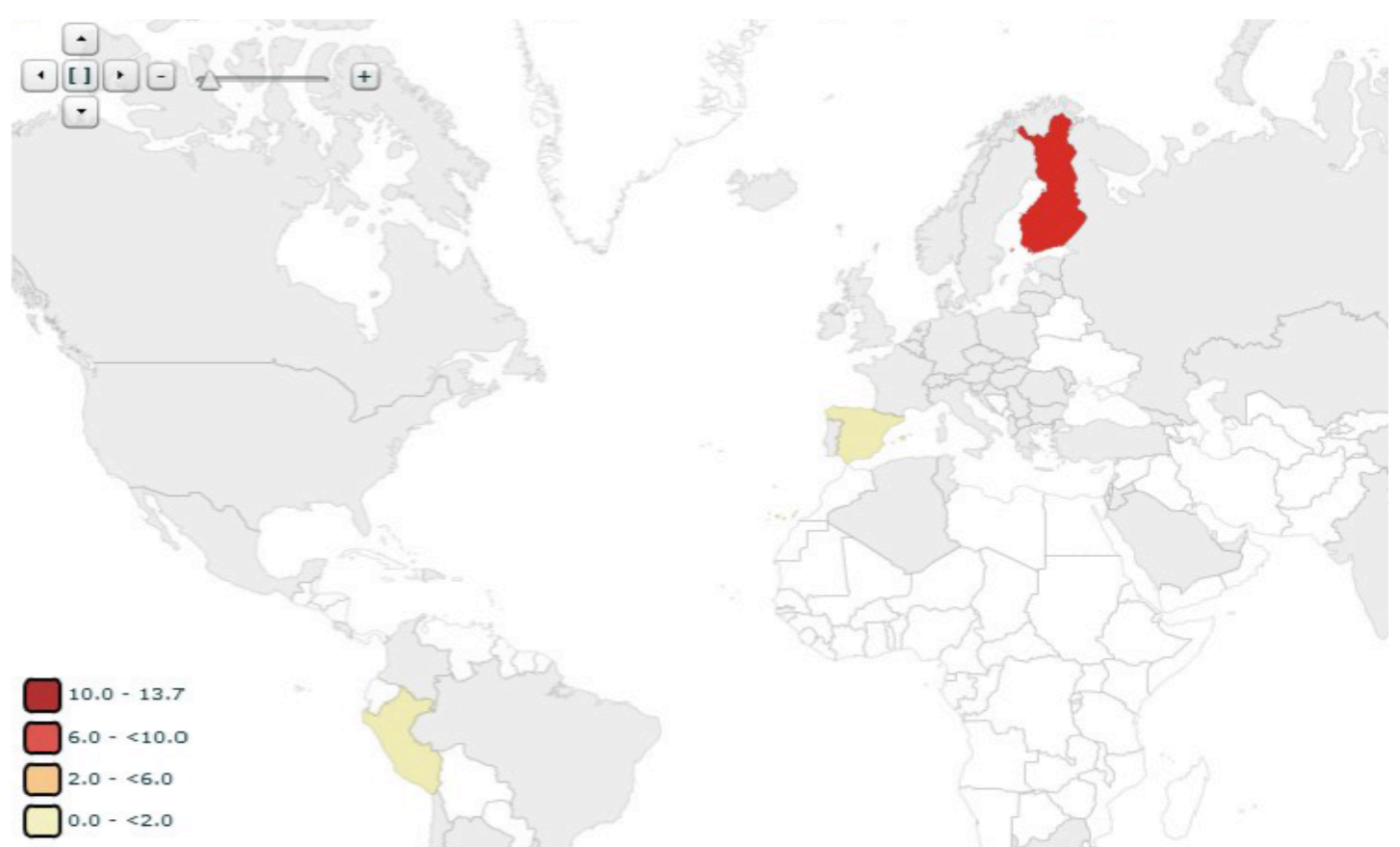

Figura 3: Top performers in all subjects (science, reading and maths) in PISA 2015, OECD (2016), p. 50.

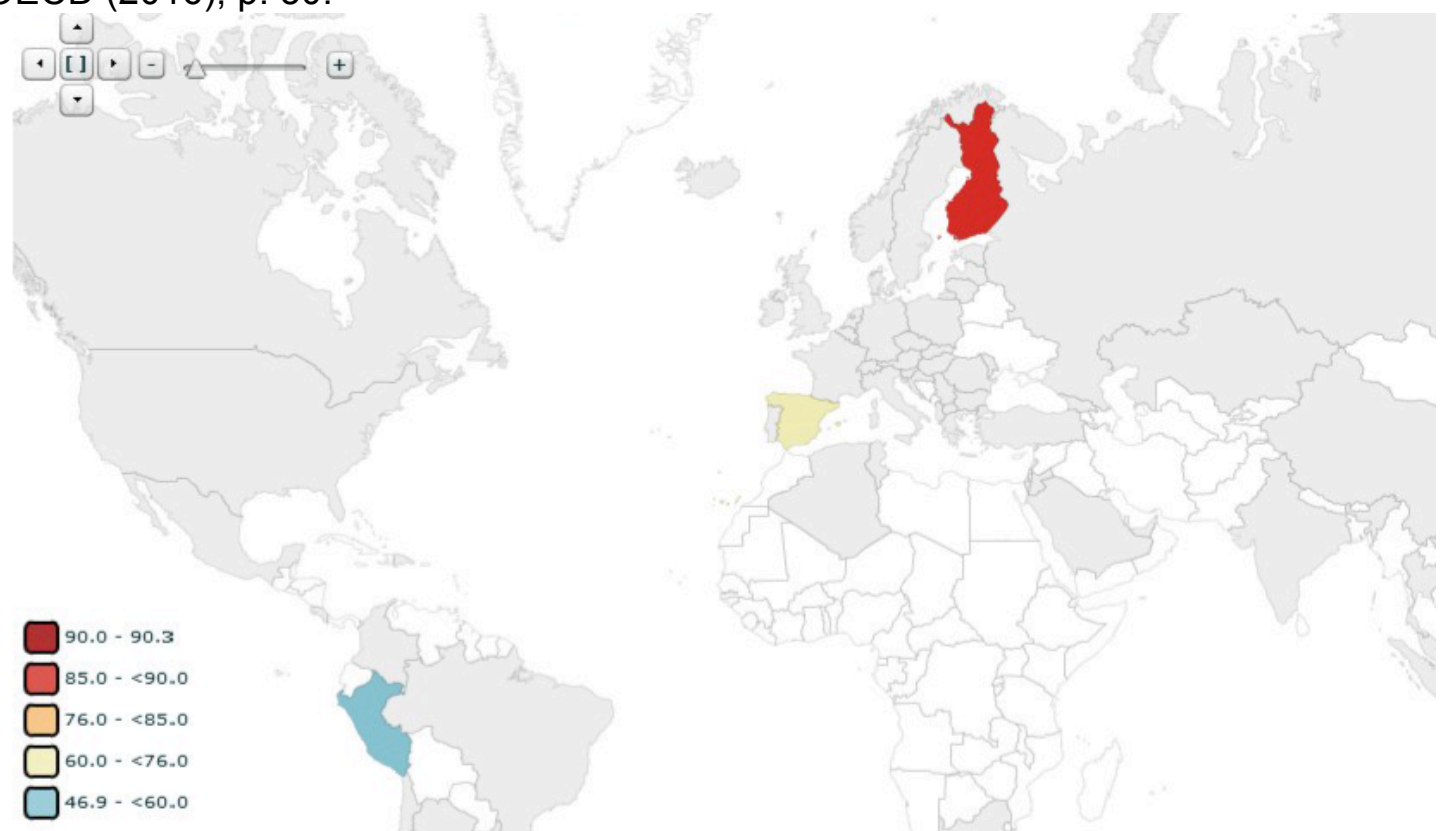

Figura 4: Index of social inclusion - percentage of the total variation ins student socio economic status within - in PISA 2105, OECD (2016), p. 202.

Sin embargo somos conscientes de que esta economía está sujeta en su mayoría al comercio y a la inversión que realizan las empresas; lo que implica que el sistema educativo está condicionado a responder a los intereses y necesidades de las mismas, a través de una rendición de cuentas, inversiones público-privadas, etcétera, convirtiéndolo en un elemento más de comercialización. A medida que esta cultura corporativa aumenta su control sobre el sistema educativo, la calidad educativa se reduce a obtención de certificados y el cumplimiento de estándares de calidad similares al de empresas como el Corte Inglés, Mercadona o Iberia. De esta manera se ve reducida la función del profesorado a imponer "una verdad oficial y estandarizada", educando para que los estudiantes cumplan el rol de un trabajador y consumidor pasivo, dejando de lado las necesidades y demandas socioculturales, que 
conlleva a que los estudiantes no tengan una participación activa en su sociedad. Chomsky (2012) "concibe a las escuelas como centros de adoctrinamiento, en tanto que imponen obediencia, bloquean todo posible pensamiento independiente e interpretan un papel institucional dentro de un sistema de control y coerción" (p. 8); idea que es compartida y que busca generar una participación más reflexiva de los gobiernos ante el sistema educativo de Sir Philip, quién fue ministro laborista en Reino Unido en el periodo de 2006 al 2009, sostiene:

La responsabilidad de los políticos es la de garantizar un consenso sobre la educación; para lo que deberían tener más claro en qué sí deben interferir como Gobierno y en qué se debería confiar más en los profesionales de la educación y familias, y redefinir el papel de la enseñanza (citado en Díaz 2017, p. 142).

Por todo ello, se considera que el sistema educativo está estancado, por lo que necesitamos cambiar los paradigmas, a través del uso de metodologías de enseñanza que generen un pensamiento crítico y creativo. Una toma de decisiones y contribuir a que el hombre sea cada vez más hombre y menos máquina (Freire, 1987); lo que implica que los estudiantes se integren con la realidad de sus sociedades, se sientan motivados de ejercer una participación ciudadana activa y consciente en la que se refuerce la identidad personal y cultural, y que sean autónomos en su proceso de enseñanza y aprendizaje. Y dejar de lado esta normalización, que como vimos surgió de una preocupación legítima por los niveles académicos en las escuelas, pero que ahora no son una respuesta que se adecue al contexto sociocultural.

Existen diversos factores que influyen en el rendimiento escolar de los estudiantes; por ejemplo está la falta de motivación e interés, las condiciones socioeconómicas pobreza, marginación social, circunstancias familiares, ausencia de infraestructura y de financiación en educación-y la presión que genera obtener certificados de calidad o subir de posición en el ranking del PISA. Robinson y Aronica (2016) sostienen que a partir de diversas investigaciones y experiencia práctica, han determinado que los "factores para aumentar el rendimiento escolar en todos los frentes son la motivación y las expectativas de los estudiantes; y ello requiere un plan de estudio amplio, equilibrado y aplicar sistemas de evaluación que sean informativos y comprensivos" (p. 57). Se debe dejar de lado el patrón industrial que se implementó hace más de 200 años y buscar un nuevo modelo y enfoque sobre la concepción de enseñanza con una metodología más apropiada a nuestra realidad.

\section{PRÓXIMOS AL CAMBIO}

Estos cambios han comenzando a iniciarse en el ámbito económico como respuesta a la era de la información y globalización que estamos viviendo. Para ello, asociaciones, empresas, entidades financieras han reestructurado el concepto de la economía por lo que ahora se habla de economías alternativas - circular, cooperativa, entre otros- y en especial de la economía creativa que busca abrir más y mejores oportunidades al pensamiento creativo-crítico, y que tiene sus antecedentes en la industria creativa en Australia en 1994. Haciendo a la producción de bienes y servicios que tiene como elemento principal a la creatividad y el capital intelectual, los cuales tienen la capacidad y potencial de generar empleos y riquezas a través del talento individual y propiedad intelectual, Programa de Naciones Unidas para el Desarrollo (PNUD, 2014). Estos cambios en los paradigmas de la economía influyen directamente en los educación, puesto que la sociedad demanda soluciones creativas frente a los acontecimientos de la sociedad: crisis financiera, contaminación, calentamiento global. Esta propuesta de economía creativa o llamada también Economía Naranja nace con la finalidad de fusionar la cultura y economía, que son el ADN de una sociedad: 
Conjunto de actividades que de manera encadenada permiten que las ideas se transformen en bienes y servicios culturales cuyo valor está determinado por su contenido de propiedad intelectual. Está compuesto por: a) La economía cultural y las industrias creativas, en cuya intersección se encuentran las industrias culturales convencionales y b) Las áreas de soporte para la creatividad (Investigación, desarrollo, innovación creativa, Formación técnica especializada, Gobernanza de propiedad intelectual y Educación creativa), Banco Interamericano de Desarrollo (BID, 2013, p. 40)

He aquí una alternativa que busca fomentar una formación que se adapte a las necesidades cambiantes, esta área de soporte llamada educación creativa fomenta y potencia el pensamiento creativo - crítico, revalorizando la identidad cultural en busca de una gestión emocional para lograr una autonomía en su proceso de enseñanza - y el aprendizaje, que se refleja en la confianza de su habilidad y potencial individual. En base a los estudios e investigaciones realizadas por especialistas en economía y finanzas del BID durante el 2013, se sostiene que si la Economía Naranja fuera un país del mundo sería:

- La cuarta economía, véase la Figura 5, generando 4,29 billones de dólares.

- El noveno país exportador de bienes y servicios, véase la Figura 6 , produciendo un ingreso de 646 mil millones de dólares.

- La cuarta fuerza laboral, véase la Figura 7, generando 144 millones de empleos.

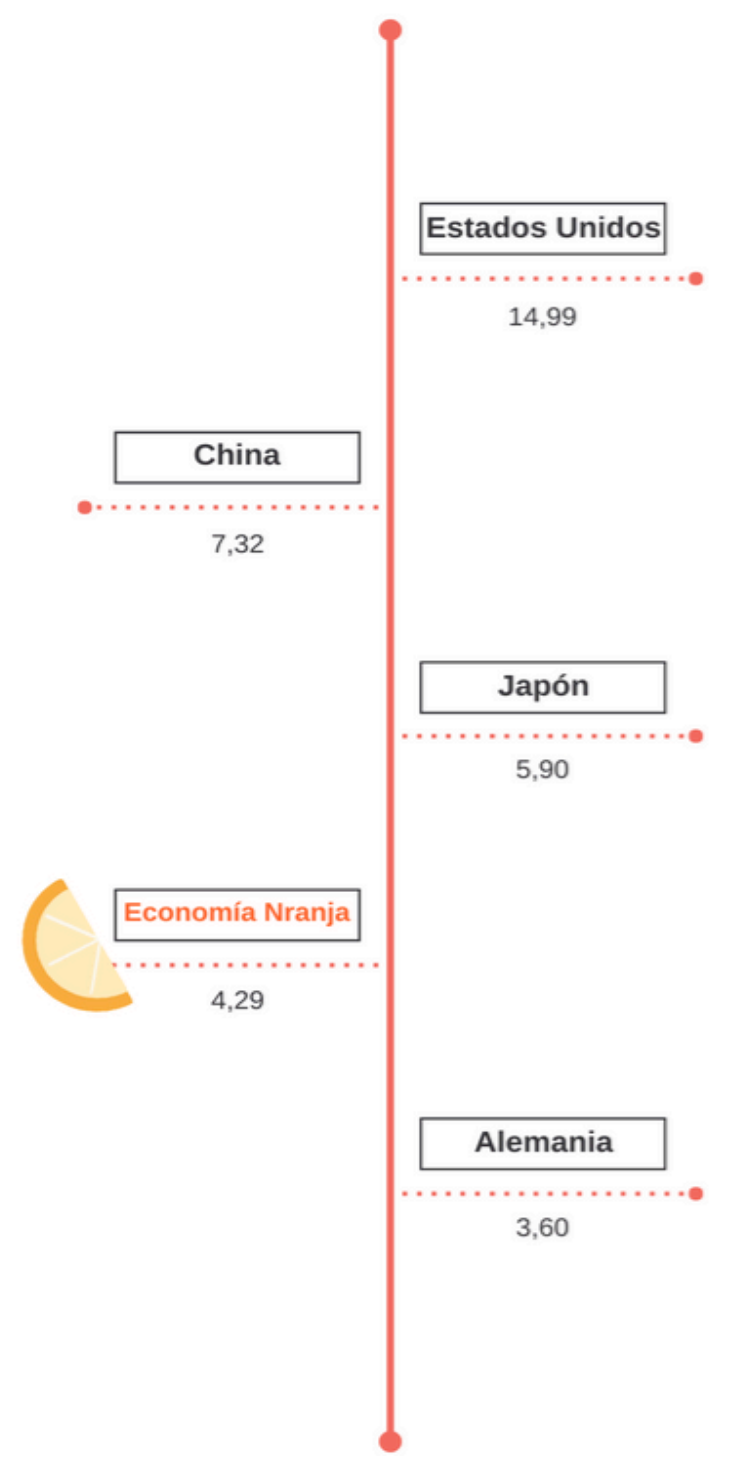


Figura 5: Cuarta economía. BID (2013), p. 96
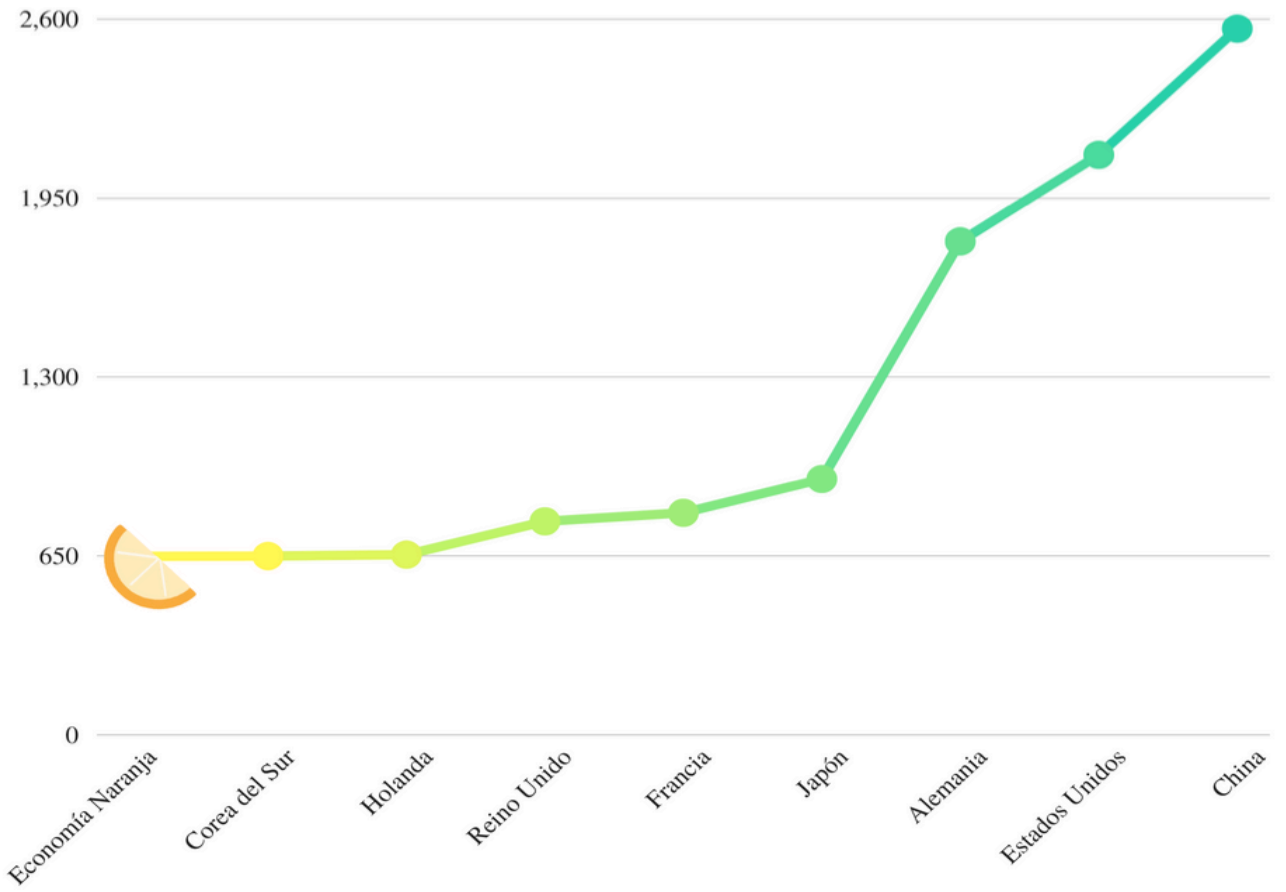

Figura 6: Noveno país exportador de bienes y servicios. BID (2013), p. 96

850

680

510

340

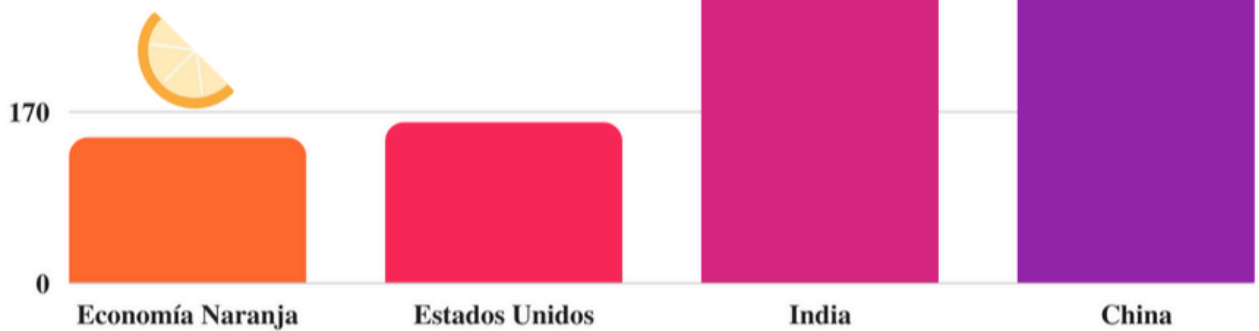

Figura 7: La cuarta fuerza laboral. BID (2013), p. 96

Los resultados de estas investigaciones nos dan a conocer los beneficios que produciría si esta economía llegará a desarrollarse, y que además responde a las demandas y necesidades de la actual Sociedad de la Información —producto de la globalización que nos permite la accesibilidad a las diversas fuentes de datos- y que lo primordial es aprender a gestionarla. La Organización de las Naciones Unidas para la Educación, la Ciencia y la Cultura -UNESCO_ en el 2004 lanzó el proyecto de Ciudades Creativas que tiene el objetivo de aprovechar el potencial creativo de las 
personas, reforzar las comunidades a través de una cooperación internacional generando una red de ciudades creativas en las que se consideran siete ámbitos de las artes: artesanía, diseño, artes digitales, cine, música, gastronomía, literatura. Actualmente es una red 72 países y 180 ciudades. Con la finalidad de dejar a un lado las diferencias geográficas, demográficas o económicas, para desarrollar e intercambiar prácticas innovadoras que refuercen la participación de la cultura en las políticas de desarrollo urbano sostenible UNESCO (2017).

La economía creativa no es ajena a los Objetivos del Desarrollo Sostenible para el 2030 - ODS 2030-promovido por el PNUD, considerados como un llamado universal para la adopción de medidas con la finalidad de poner fin a la pobreza, proteger el planeta y garantizar que todas las personas gocen de paz y prosperidad. Como respaldo a ello, en el 2005 establecieron cuatro objetivos principales para apoyar la agenda del ODS 2030, véase la Figura 8. Durante la Convención sobre la Protección y la Promoción de la Diversidad de las Expresiones Culturales desarrollada por la UNESCO (2005) se manifiesta que "con el objetivo de establecer principios para la elaboración y aplicación de las políticas y medidas que ofrezcan el apoyo adecuado a las creaciones culturales que forman parte fundamental de la economía creativa" y en base a ellos promover entornos favorables en que las personas y grupos sociales puedan crear, producir y acceder a una amplia variedad de expresiones culturales.

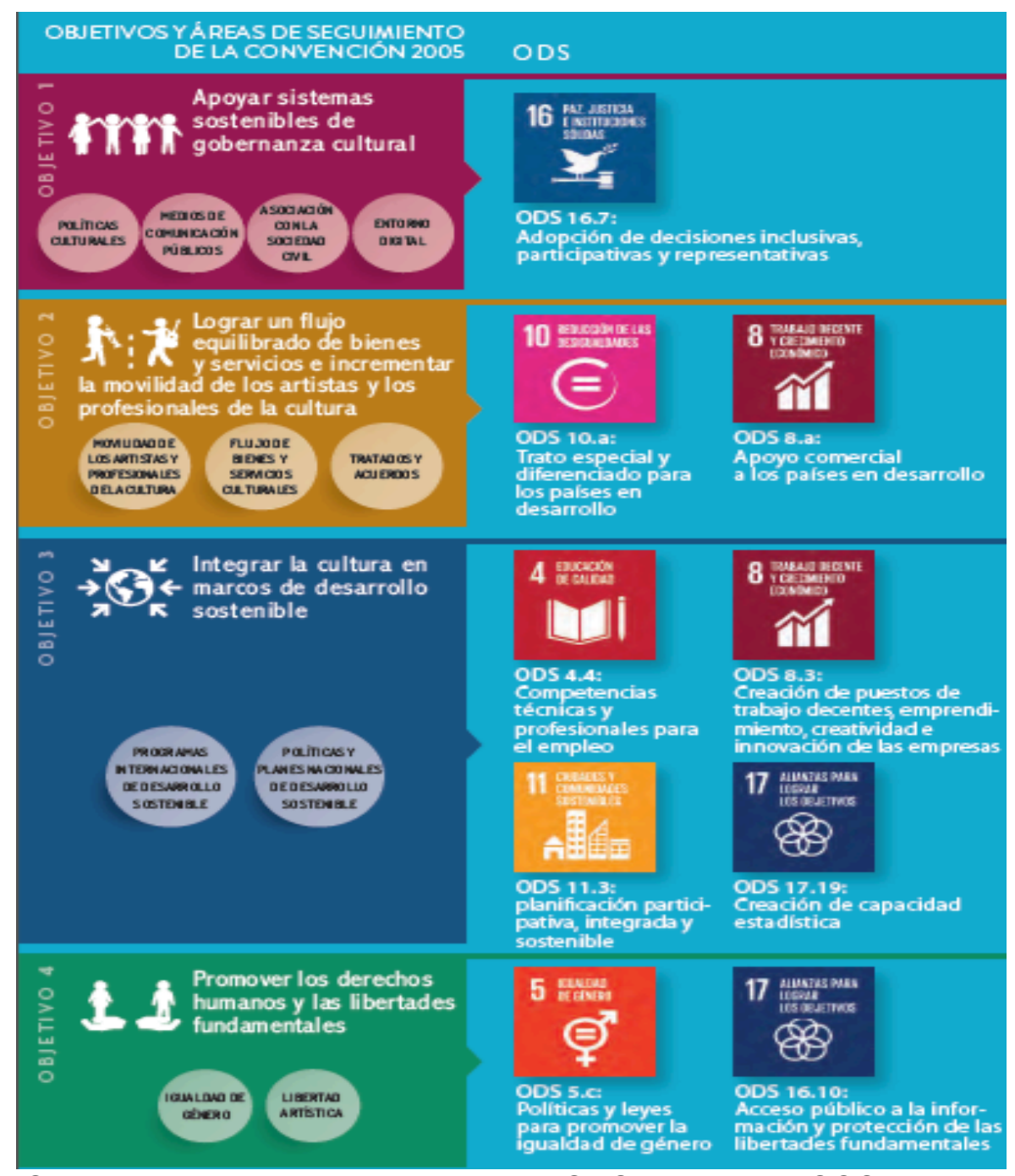

Figura 8: Objetivos principales para apoyar los ODS 2030. (UNESCO, 2005)

Asimismo, se considera oportuno señalar que para lograr el potencial económico de la creatividad es necesario consolidar una serie de cimientos que van desde los 
acuerdos internacionales hasta infraestructuras tecnológicas y comunicativas, especialmente poder asegurar educación y capacitación adecuadas a los nuevos perfiles y nuevas profesiones (Fonseca, 2008). Dicha idea es reforzada por el World Economic Forum Report del 2016, el cual señala que para el 2020 más de un tercio de las habilidades $(35 \%)$ que se consideran importantes para desempeñar un trabajo actual habrán cambiado, debido a que la Cuarta Revolución Industrial traerá consigo avances en robótica, transporte autónomo, inteligencia artificial, biotecnología y aprendizaje automático; teniendo impacto en nuestra forma de vida y en los diversos aspectos de la misma por lo que los principales agentes de recursos humanos encargados de los procesos de selección y reclutamiento en las industrias nivel mundial- han elaborado un reporte sobre "The Future of Jobs" en el que nos dan a conocer las diez habilidades principales que responderán a las necesidades socioeconómicas a partir del 2020, véase Figura 9.

\section{Top 10 skills}

\begin{tabular}{ll} 
in & $\mathbf{2 0 2 0}$ \\
\hline 1. & Complex Problem Solving \\
2. & Critical Thinking \\
3. & Creativity \\
4. & People Management \\
5. & Coordinating with Others \\
6. & Emotional Intelligence \\
7. & Judgment and Decision Making \\
8. & Service Orientation \\
9. & Negotiation \\
10. & Cognitive Flexibility
\end{tabular}

Figura 9: Top ten skills you need. (World Economic Forum,2016)

Como se puede observar, habilidades como el pensamiento crítico, creatividad e inteligencia emocional figuran dentro de esta lista reforzando una vez más la idea de generar cambios en los paradigmas educativos, que en su mayoría solo buscan potenciar el rendimiento académico dejando de lado las habilidades intra e interpersonales. Debido a ello, la educación, además de facilitar el acceso a una formación, debe permitir el desarrollo de las habilidades como la selección y el procesamiento de la información, la negociación, servicio de orientación, autonomía en el aprendizaje, la capacidad para tomar decisiones, resolución de problemas, el trabajo en equipo, la flexibilidad.

Hay un cansancio generalizado en torno a la tendencia de alimentar el cerebro de los niños con datos que deben memorizar, un consenso enorme sobre que el rol de la escuela es ayudar a aprender, despertar la curiosidad y capacitar a los niños y niñas con las habilidades que requieren para aprender toda la vida. (...) Pero sobre todo, es muy importante entablar una conversación permanente con los trabajadores de la enseñanza, escuchar sus necesidades y darles verdadera participación en las reformas que nos sean meros implementadores, sino protagonistas. Que se adueñen del cambio, por su puesto, esto resulta mucho más difícil, pero es más sostenible (Sir Philip citado en Díaz, 2017, p. 143)

De allí la importancia de conocer y comprender qué es lo que se viene realizando con los procesos de enseñanza en las aulas, especialmente el rol del docente. Se han venido desarrollando diversas investigaciones y estudios relacionados a cómo los profesores y estudiantes conceptualizan sus procesos de enseñanza y aprendizaje 
(Monroy, 2013), lo que supone la correlación entre el contexto, véase Figura 10.

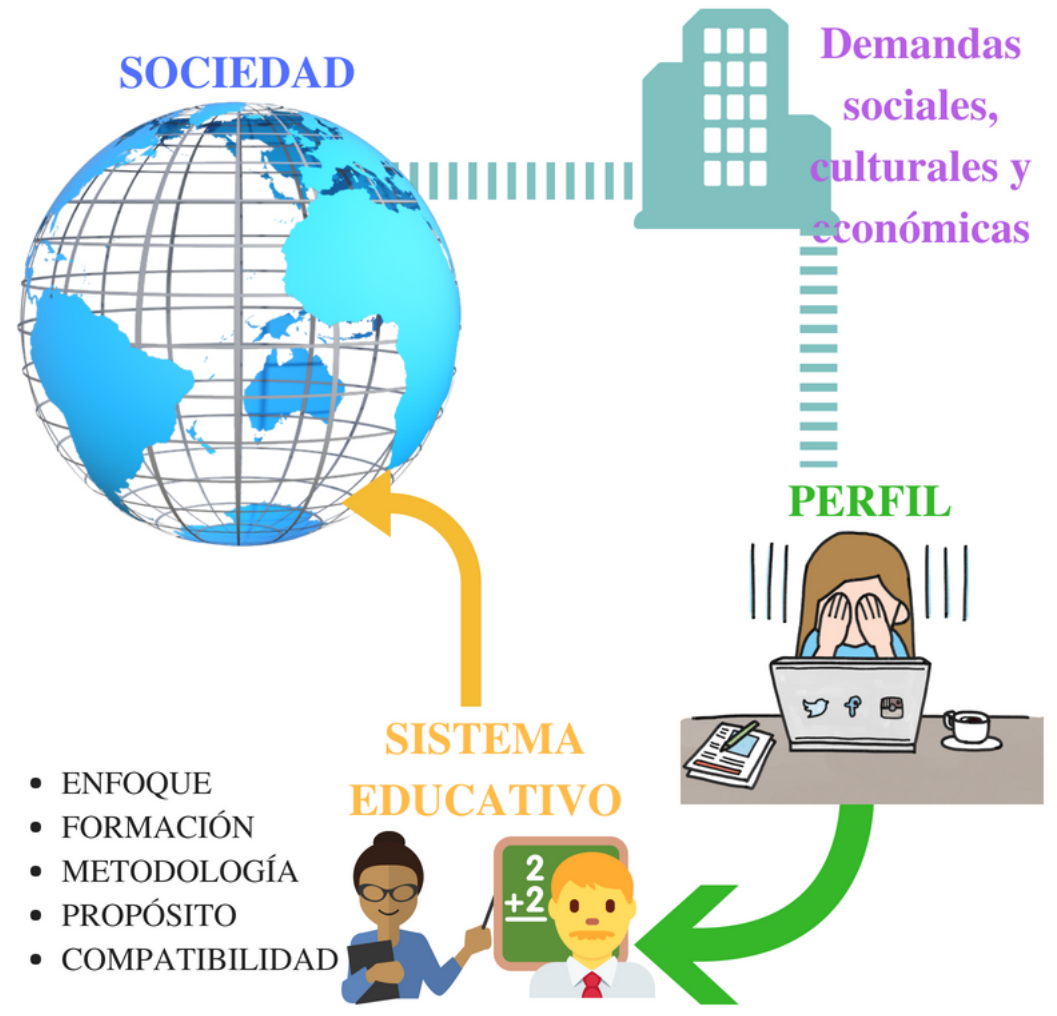

Figura 10: Correlación entre las demandas de la sociedad y las demandas del sistema educativo. Elaboración propia.

Como se visualiza en la figura, las demandas de la sociedad, que están basándose en factores económicos, culturales, históricos, entre otros, requieren de un conjunto de competencias y habilidades que se reflejan en los perfiles de los futuros ciudadanos que deberán ser atendidos por el sistema educativo, que implica el enfoque de enseñanza, metodología de enseñanza, el propósito y compatibilidad con las demandas socioculturales.

\section{¿SE ESTÁ ENSEÑANDO PARA EL FUTURO?}

Para ello cabe mencionar que a partir de los años 80 , se comienza a considerar la enseñanza y aprendizaje en educación como un campo de estudio; y posteriormente se logra establecer una relación entre la calidad de la enseñanza y calidad del aprendizaje (Biggs, 2015). En el informe "La cuestión del profesorado: atraer, capacitar y conservar a profesores eficientes" se señala:

(...) Existe actualmente un volumen considerable de investigación que indica que la calidad de los profesores y de su enseñanza es el factor más importante para explicar los resultados de los estudiantes. El mejorar la eficacia y la equidad de la escolaridad depende, en gran medida, de que pueda garantizarse que los profesores sean personas competentes, que su enseñanza sea de calidad y que todos los estudiantes tengan acceso a una docencia de excelente calidad. (...) Los profesores deben ser capaces de preparar a los estudiantes para una sociedad y una economía que esperan de ellos autonomía en el aprendizaje, aptitud y motivación para seguir aprendiendo a lo largo de toda su vida (OECD, 2005, p. 1-3).

En base a ello se considera fundamental conocer las concepciones y el enfoque de enseñanza que presenta y desarrolla el profesorado en su desempeño profesional, puesto que influye en la concepción sobre el proceso de aprendizaje de los 
estudiantes. Para Lam \& Kember (2006) "las concepciones sobre la enseñanza pueden considerarse como: las creencias sobre la enseñanza que guían la percepción sobre una situación que tienen los profesores y que modelan sus acciones". Estas creencias influyen en las concepciones de los estudiantes sobre el aprendizaje, una referencia a ello se puede visualizar en los siguientes testimonios de tres estudiantes con contextos socioculturales completamente diferentes, que acaban de terminar sus estudios básicos y tienen la creencia de que la escuela convierte a los estudiantes en zombies y que no atienden a los intereses de los estudiantes; estos testimonios se basan en la experiencia de aprendizaje que les tocó vivir con sus profesores e institución educativa:

(...) nos enseñan a repetir los procesos, las fórmulas, todo se vuelve mecánico. (...) Todos los días durante muchos años se repite lo mismo: pizarrón, carpeta, prueba (...) Yo no sabía qué estaba haciendo cuando hacía ejercicios, solo repetía lo que me habían enseñado; porque la escuela nos acostumbra a pensar y creer que si no vimos como se resuelve algo puntual, entonces no lo podemos resolver (...) El sistema educativo en todo el mundo está mal y está convirtiendo a las nuevas generaciones en zombis (Garbulsky, 2017).

(...) depende del profesor o profesora que te toque, pero eso no es justo. Yo creo que si algo puede salvar a la educación con los profesores.(...) porque la mayoría de los empleos en menos de 50 años a lo mejor se van a ir a tomar por saco porque los van a reemplazar los robots. Y sin embargo, las cosas que no puede hacer una maquina, las cosas que no se pueden automatizar no nos enseñan a hacerlas, como aprender a pensar, cuestionar, incentivar a nuestra imaginación (...) (Davó citado en Díaz 2017, p. 18 - 26).

Nada podría haber sido peor para mi mente que esta escuela, porque era estrictamente clásica y no se impartía nada más aparte de un poco de geografía e historia. La escuela como instrumento educativo fue para mí un completo vacío. Durante toda mi vida he sido totalmente incapaz de dominar una lengua (...) El único placer que me aportaron estos estudios fueron algunas odas de Horacio que yo admiraba mucho (Darwin, citado en Robinson y Arinoca 2016, p. 345).

Zabalza Beraza y Zabalza Cerdeiriña (2012) "hemos convertido la agradable experiencia de aprender algo nuevo cada día, en un inexcusable principio de supervivencia" (p. 12). Esta afirmación no es ajena a lo que se evidencia actualmente, según la OCDE (2016) el $24 \%$ de los jóvenes españoles dejan sus estudios antes de finalizar la educación secundaria y a nivel mundial se evidencia que una de cada seis personas entre 25 y 34 años dejó de estudiar antes de completar la educación media superior. La última edición de El Panorama de la Sociedad del 2016 manifiesta que la parte de jóvenes que no estudian ni trabajan —llamados Ninis- aumentó en el 2015, llegando a 40 millones entre los países que forman parte de la OCDE, quien además considera indispensable combatir la deserción escolar prematura, véase Figura 11. 


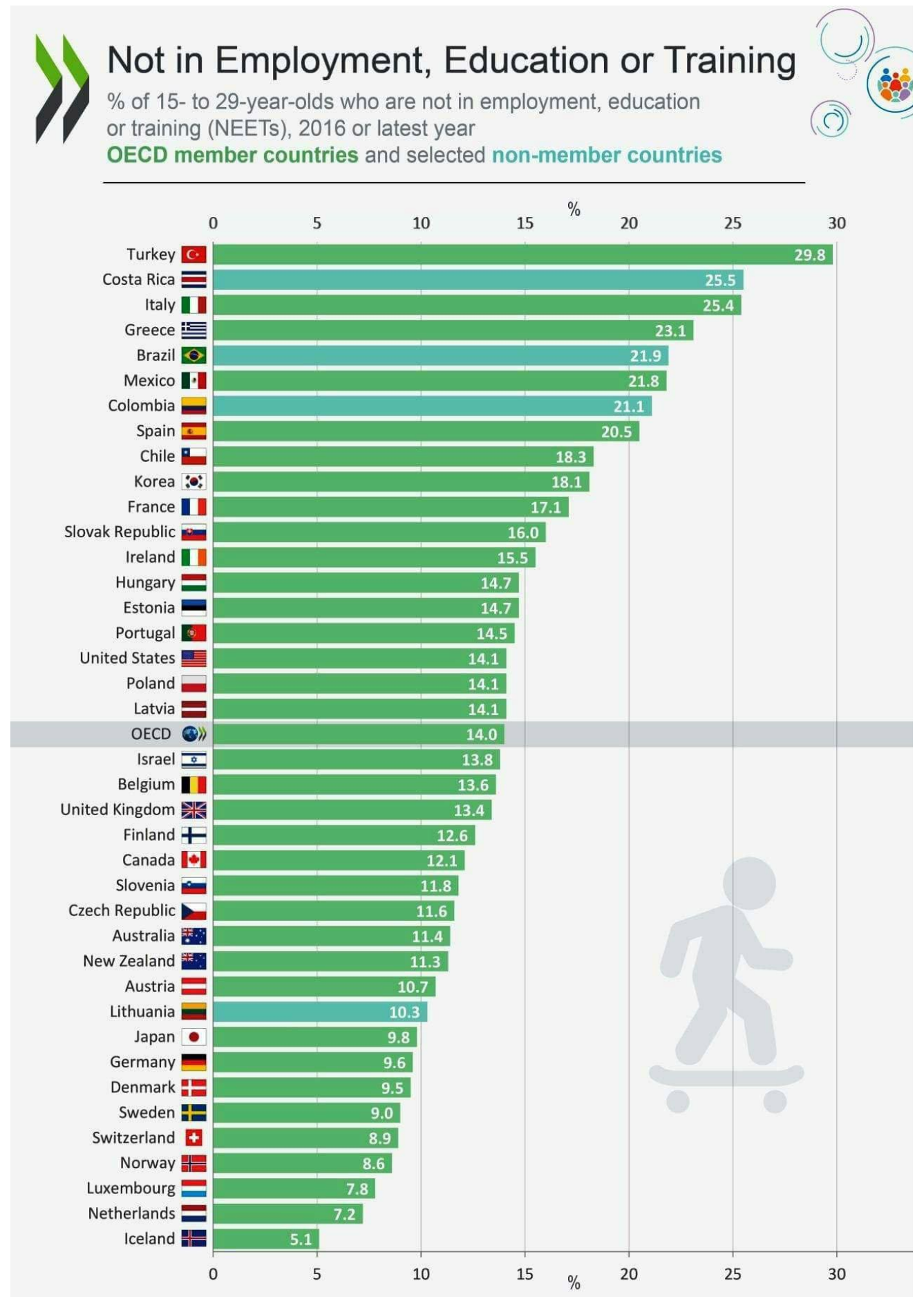

Figura 11: Porcentaje de jóvenes entre 15 a 29 años que no trabajan ni estudian. (OECD, 2016)

A finales de los años 90 Kember (citado por Monroy 2013) revisó los trece estudios más destacados hasta esa fecha centrados en analizar las concepciones de enseñanza, cabe mencionar que ellos tomaron un enfoque cualitativo para la recogida de datos y se desarrollaron en un marco naturalista; entre los que destaca Dall Alba, (1991); Dunkin and Precians (1992); Fox (1983); Gow \& Kember (1990); Pratt (1992); Prosser, et al. (1994) y Trigwell, et al. (1994); una de las taxonomías más conocidas y utilizadas en la investigación ha sido la propuesta por Samelowicz y Bain (1992) que identifican siete concepciones de enseñanza:

- Impartir información 
- Transmitir conocimiento

- Facilitar el aprendizaje

- Cambiar las concepciones de los estudiantes

- Apoyar el aprendizaje de los estudiantes

- Negociar los significados

- Promover la creación del conocimiento

Estas concepciones se verán reflejadas en el actuar docente, en ellas se pondrá de manifiesto los propósitos y estrategias que ponen en funcionamiento dentro del contexto educativo donde se tendrá en cuenta tres aspectos: ¿Qué es lo que presenta?, ¿cuándo lo presenta? y ¿cómo lo presenta?, todo ello vendrá a ser el Enfoque de Enseñanza. Cabe mencionar que dicho enfoque tienen su origen con los enfoques de aprendizaje y que gracias a los diversos estudios e investigaciones realizadas - con una perspectiva fenomenográfica - con esta misma dependencia contextual los profesores enfocan su enseñanza, véase la Tabla 1 donde se relacionan los principales trabajos que dan a conocer el origen y evolución de este constructo (Cárdenas, Hernández Pina, Monroy y Soler, 2017).

Tabla 1: Aproximaciones investigativas que dieron origen la teoría de los enfoques de enseñanza

\begin{tabular}{|c|c|c|c|c|}
\hline Publicación & Año & Título & Autores & Ideas Centrales \\
\hline $\begin{array}{l}\text { Edinburgh: } \\
\text { Educational } \\
\text { Research } \\
\text { Publications } \\
\text { University of } \\
\text { Edinburgh }\end{array}$ & 1984 & $\begin{array}{l}\text { Understanding } \\
\text { Teaching and } \\
\text { Teaching for } \\
\text { Understanding } \\
\text { capítulo XV }\end{array}$ & Hounsell, D. & $\begin{array}{l}\text { Se preocupa por los } \\
\text { enfoques de enseñanza y } \\
\text { su repercusión en el } \\
\text { enfoque de aprendizaje } \\
\text { visto desde la perspectiva } \\
\text { de los estudiantes. }\end{array}$ \\
\hline $\begin{array}{l}\text { Britush Journal } \\
\text { of Educational } \\
\text { Psychology, } \\
63,20-23\end{array}$ & 1993 & $\begin{array}{l}\text { Conceptions of } \\
\text { teaching and their } \\
\text { relationship to } \\
\text { student learning }\end{array}$ & $\begin{array}{l}\text { Trigwell, K., } \\
\text { Prosser, M., } \\
\text { Martin, E. M. y } \\
\text { Ramsden, P. }\end{array}$ & $\begin{array}{l}\text { Describe el diseño y la } \\
\text { validación de un } \\
\text { cuestionario para analizar } \\
\text { las concepciones sobre la } \\
\text { enseñanza por parte de los } \\
\text { profesores y su relación con } \\
\text { el aprendizaje de los } \\
\text { estudiantes. }\end{array}$ \\
\hline $\begin{array}{l}\text { Higher } \\
\text { Education, } \\
\text { 32, 347-364 }\end{array}$ & 1996 & $\begin{array}{l}\text { Enhancing } \\
\text { teaching } \\
\text { through } \\
\text { constructive } \\
\text { alignment }\end{array}$ & Biggs, J. W. & $\begin{array}{l}\text { Describe, tomando como } \\
\text { ejemplo la formación en un } \\
\text { programa de psicología, la } \\
\text { forma como debe funcionar } \\
\text { el alineamiento constructivo, } \\
\text { y afirma que esto se puede } \\
\text { aplicar a cualquier otro } \\
\text { programa de formación. }\end{array}$ \\
\hline $\begin{array}{l}\text { Higher } \\
\text { Education, } \\
37,57-70\end{array}$ & 1999 & $\begin{array}{l}\text { Relations } \\
\text { between } \\
\text { teachers' } \\
\text { approaches to } \\
\text { teaching and } \\
\text { students' } \\
\begin{array}{l}\text { approaches } \\
\text { learning }\end{array}\end{array}$ & $\begin{array}{l}\text { Trigwell, K., } \\
\text { Prosser, M. y } \\
\text { waterhouse, } \\
\text { F. }\end{array}$ & $\begin{array}{l}\text { Estudio empírico que } \\
\text { muestra cómo se relaciona } \\
\text { el enfoque de enseñanza de } \\
\text { los profesores con el } \\
\text { enfoque de aprendizaje de } \\
\text { los estudiantes. }\end{array}$ \\
\hline Higher & 2000 & Scholarship & Trigwell, K., & exploran \\
\hline
\end{tabular}




\begin{tabular}{|c|c|c|c|c|}
\hline $\begin{array}{l}\text { Education } \\
\text { Research y } \\
\text { Development, } \\
37,155-168\end{array}$ & & teaching: A model & $\begin{array}{l}\text { Martin, E., } \\
\text { Benjamin, J. y } \\
\text { Prosser, M. }\end{array}$ & $\begin{array}{l}\text { concepciones de enseñanza } \\
\text { que hay en la literatura y se } \\
\text { contrastan con lo que } \\
\text { manifiestan los profesores. } \\
\text { A partir de esta información, } \\
\text { se obtiene un modelo } \\
\text { multidimensional del } \\
\text { enfoque de enseñanza que } \\
\text { recoge la variación } \\
\text { encontrada en la literatura y } \\
\text { en los estudios empíricos. }\end{array}$ \\
\hline $\begin{array}{l}\text { Studies in } \\
\text { Higher } \\
\text { Education, } \\
37,247-259\end{array}$ & 2003 & $\begin{array}{l}\text { Variation in the } \\
\text { experience of } \\
\text { leadership of } \\
\text { teaching in higher } \\
\text { education }\end{array}$ & $\begin{array}{l}\text { Martin, E. y } \\
\text { Trigwell, K. } \\
\text { Prosser, M. y } \\
\text { Ramsden, P. }\end{array}$ & $\begin{array}{l}\text { Es un estudio sobre el } \\
\text { liderazgo de los profesores } \\
\text { influenciada por sus } \\
\text { coordinadores } \\
\text { departamento. de } \\
\text { resultados proporcionan } \\
\text { evidencia } \\
\text { de que la experiencia de } \\
\text { liderazgo académico tiene } \\
\text { un impacto en la calidad del } \\
\text { aprendizaje de los } \\
\text { estudiantes. }\end{array}$ \\
\hline $\begin{array}{l}\text { Educational } \\
\text { Psychology } \\
\text { Review, } \\
16(4), 409-427\end{array}$ & 2004 & $\begin{array}{l}\text { Development and } \\
\text { use } \\
\text { of the approaches } \\
\text { to } \\
\text { teaching inventory }\end{array}$ & $\begin{array}{l}\text { Trigwell, K. y } \\
\text { Prosser, M. }\end{array}$ & $\begin{array}{l}\text { Se realiza una revisión del } \\
\text { approaches to teaching } \\
\text { inventory (ATI) verificando } \\
\text { su validez y comprobando } \\
\text { que permite establecer } \\
\text { relaciones entre el enfoque } \\
\text { de enseñanza de los } \\
\text { profesores y el enfoque de } \\
\text { aprendizaje de los } \\
\text { estudiantes. }\end{array}$ \\
\hline $\begin{array}{l}\text { Higher } \\
\text { Education } \\
\text { Research y } \\
\text { Development, } \\
\text { 24, 349-360 }\end{array}$ & 2005 & $\begin{array}{l}\text { Phenomenograph } \\
\text { ic } \\
\text { pedagogy and a } \\
\text { revised } \\
\text { approaches to } \\
\text { teaching inventory }\end{array}$ & $\begin{array}{l}\text { Trigwell, K., } \\
\text { Prosser, M. y } \\
\text { Ginns, P. }\end{array}$ & $\begin{array}{l}\text { Se realiza un reporte de las } \\
\text { múltiples aplicaciones del } \\
\text { approaches to teaching } \\
\text { inventory (ATI) tanto en su } \\
\text { primera versión como en la } \\
\text { versión modificada. }\end{array}$ \\
\hline $\begin{array}{l}\text { Teaching in } \\
\text { Higher } \\
\text { Education, } \\
10,251-264\end{array}$ & 2005 & $\begin{array}{l}\text { University } \\
\text { teachers' } \\
\text { experiences of } \\
\text { change in their } \\
\text { understanding of } \\
\text { the subject matter } \\
\text { they have taught }\end{array}$ & $\begin{array}{l}\text { Trigwell, K., } \\
\text { Prosser, M., } \\
\text { Martin, E. M. y } \\
\text { Ramsden, P. }\end{array}$ & 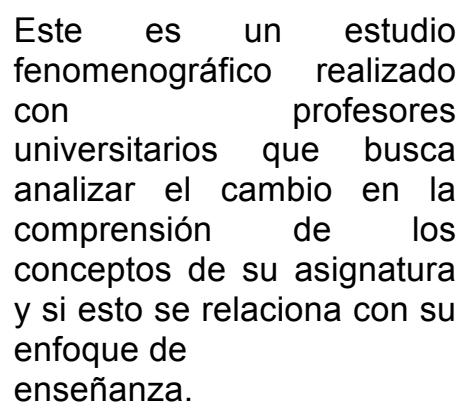 \\
\hline $\begin{array}{l}\text { Studies in } \\
\text { Higher } \\
\text { Education, } \\
\text { 31, 285-298 }\end{array}$ & 2006 & $\begin{array}{l}\text { How approaches } \\
\text { to } \\
\text { teaching } \quad \text { are } \\
\text { affected } \\
\text { discipline } \\
\text { teaching }\end{array}$ & $\begin{array}{l}\text { Lindblom- } \\
\text { Ylännea, S., } \\
\text { Trigwell, K., } \\
\text { Nevgi, A. y } \\
\text { Ashwin, P. }\end{array}$ & $\begin{array}{l}\text { Se exploran los resultados } \\
\text { de dos estudios que } \\
\text { analizan el área de } \\
\text { desempeño académico y el } \\
\text { contexto con los enfoques } \\
\text { de enseñanza de los }\end{array}$ \\
\hline
\end{tabular}




\begin{tabular}{|c|c|c|c|c|}
\hline & & context & & profesores. \\
\hline $\begin{array}{l}\text { Learning and } \\
\text { Instruction, } \\
17,140-155\end{array}$ & 2007 & $\begin{array}{l}\text { University } \\
\text { teachers' } \\
\text { experiences of } \\
\text { academic } \\
\text { leadership and } \\
\text { their approaches } \\
\text { to teaching }\end{array}$ & $\begin{array}{l}\text { Ramsden, P., } \\
\text { Prosser, M., } \\
\text { Trigwell, K. y } \\
\text { Martin, E. }\end{array}$ & $\begin{array}{l}\text { Se analizó la influencia del } \\
\text { liderazgo docente y el } \\
\text { contexto en el enfoque de } \\
\text { enseñanza de un tema } \\
\text { particular en ese contexto. }\end{array}$ \\
\hline $\begin{array}{l}\text { International } \\
\text { Journal for the } \\
\text { Scholarship of } \\
\text { Teaching and } \\
\text { Learning, } \\
5,2-7\end{array}$ & 2011 & $\begin{array}{l}\text { Scholarship of } \\
\text { teaching and } \\
\text { teachers' } \\
\text { understanding of } \\
\text { subject matter }\end{array}$ & Trigwell, K. & $\begin{array}{l}\text { Analiza la relación que se } \\
\text { presenta entre una visión } \\
\text { general de los } \\
\text { conocimientos y una visión } \\
\text { atomizada por parte de los } \\
\text { profesores y el enfoque de } \\
\text { enseñanza adoptado. }\end{array}$ \\
\hline $\begin{array}{l}\text { Educational } \\
\text { Psychology, } \\
25,673-680\end{array}$ & 2005 & $\begin{array}{l}\text { Students' } \\
\text { approaches to } \\
\text { learning and } \\
\text { teachers' } \\
\text { approaches to } \\
\text { teaching in higher } \\
\text { education }\end{array}$ & Richardson, J. & $\begin{array}{l}\text { Estudia las relaciones entre } \\
\text { los } \\
\text { enfoques de aprendizaje de } \\
\text { los } \\
\text { estudiantes y los enfoques } \\
\text { de } \\
\text { enseñanza de los } \\
\text { profesores, } \\
\text { relacionándolos con la } \\
\text { mejora de los procesos de } \\
\text { formación en los diferentes } \\
\text { programas académicos. }\end{array}$ \\
\hline Madrid: Narcea & 2005 & $\begin{array}{ll}\text { Calidad } & \text { del } \\
\text { Aprendizaje } & \\
\text { Universitario } & \end{array}$ & Biggs, J. W. & $\begin{array}{l}\text { En el capítulo dos, se } \\
\text { realiza una categorización } \\
\text { de docentes en tres niveles } \\
\text { según si enfocan su } \\
\text { enseñanza centrándose en } \\
\text { lo que el estudiantes es } \\
\text { (nivel 1), en lo que el } \\
\text { docente es (nivel 2), o en lo } \\
\text { que el estudiante hace (nivel } \\
\text { 3). }\end{array}$ \\
\hline
\end{tabular}

Fuente: Elaborado por Cárdenas, Hernández - Pina, Monroy y Soler (2017).

Los resultados de estas investigaciones han posibilitado establecer importantes relaciones entre los enfoques de aprendizaje que asumen los estudiantes con los de enseñanza adoptados por los docentes. Los cuales permiten deliberar sobre cómo orientar y canalizar los esfuerzos y desempeño del profesorado y estudiantes con la finalidad de mejorar la comprensión de lo que implica lograr y desarrollar un aprendizaje (Cárdenas, et. al 2017). Al igual que el modelo de enfoques de aprendizaje, que están definidos por motivos y estrategias, autores como Trigwell, Prosser y Taylor en 1994 establecieron cinco enfoques de enseñanza (citado por Hernández-Pina, Maquilón y Monroy 2012, p. 6 y p. 7):

- A: Estrategia centrada en el profesor con la intención de transmitir información a los estudiantes. El profesor no tiene en cuenta el conocimiento previo del estudiante y asume que este puede aprender sin participar activamente.

- B: Estrategia centrada en el profesor con la intención de que el estudiante adquiera los conceptos de la disciplina. El profesor asume que el hecho de comunicar conceptos hará que los estudiantes los aprendan y sean capaces de recordar los hechos y 
resolver los problemas.

- C: Estrategias interactivas entre el profesor y estudiantes con el fin de que adquieran conceptos de la asignatura. El profesor se implica más con la interacción con el estudiante a medida que los estudiantes van adquiriendo mayor protagonismo.

- D: Estrategia centrada en los estudiantes con la intención de promover el desarrollo conceptual en los estudiantes. Quiénes comienzan a ser protagonistas, pues deben construir sus propios conocimientos para desarrollar sus propias concepciones de aprendizaje.

- E: Estrategia centrada en los estudiantes con la intención de promover cambios conceptuales en ellos. El protagonista es el estudiante y el profesor ayuda en el cambio de su visión del mundo. En este enfoque el estudiante debe reconstruir sus conocimientos para desarrollar una nueva visión del mundo o nuevas concepciones.

Reduciéndose posteriormente en dos grandes categorías; puesto que las estrategias centrados en el estudiantes ( $D$ y $E$ ) guardan relación con el enfoque profundo de aprendizaje, y las estrategias centradas en el profesorado ( $A, B$ y C) con el enfoque superficial:

1. Enfoque centrado en la transmisión de conocimiento o en el Profesor - Information Transmision / Teacher-Focused Approach, ITTF); conceptualizan la enseñanza como una transmisión de la información percibiendo al profesorado como protagonista principal del proceso; centrándose fundamentalmente en los contenidos de las materias y en la que el estudiante manifiesta una actitud pasiva como receptor de la información que se le brinda y que ha sido organizada por el profesor.

2. Enfoque centrado en el cambio conceptual o en el Estudiante -Conceptual Change / Student- Focused Approach, CCSF); conceptualiza la enseñanza como una construcción del conocimiento situando a los estudiantes en el centro del proceso; en la que el profesorado se percibe como facilitador para que los estudiantes construyan su propio conocimiento y comprensión, buscando que sean más independientes y gestionen su propio proceso de aprendizaje.

En un avance sobre la línea de enfoques Prosser \& Trigwell en 1999 (citado por Hernández Pina, et. al 2012) hicieron una integración del modelo 3P —representa la relación entre factores personales y contextuales, los enfoques de aprendizaje y los resultados de aprendizaje- desarrollado en 1989 por Biggs con los enfoques de enseñanza; con la finalidad de poder estudiar la relación entre ambos enfoques, véase Figura 12.

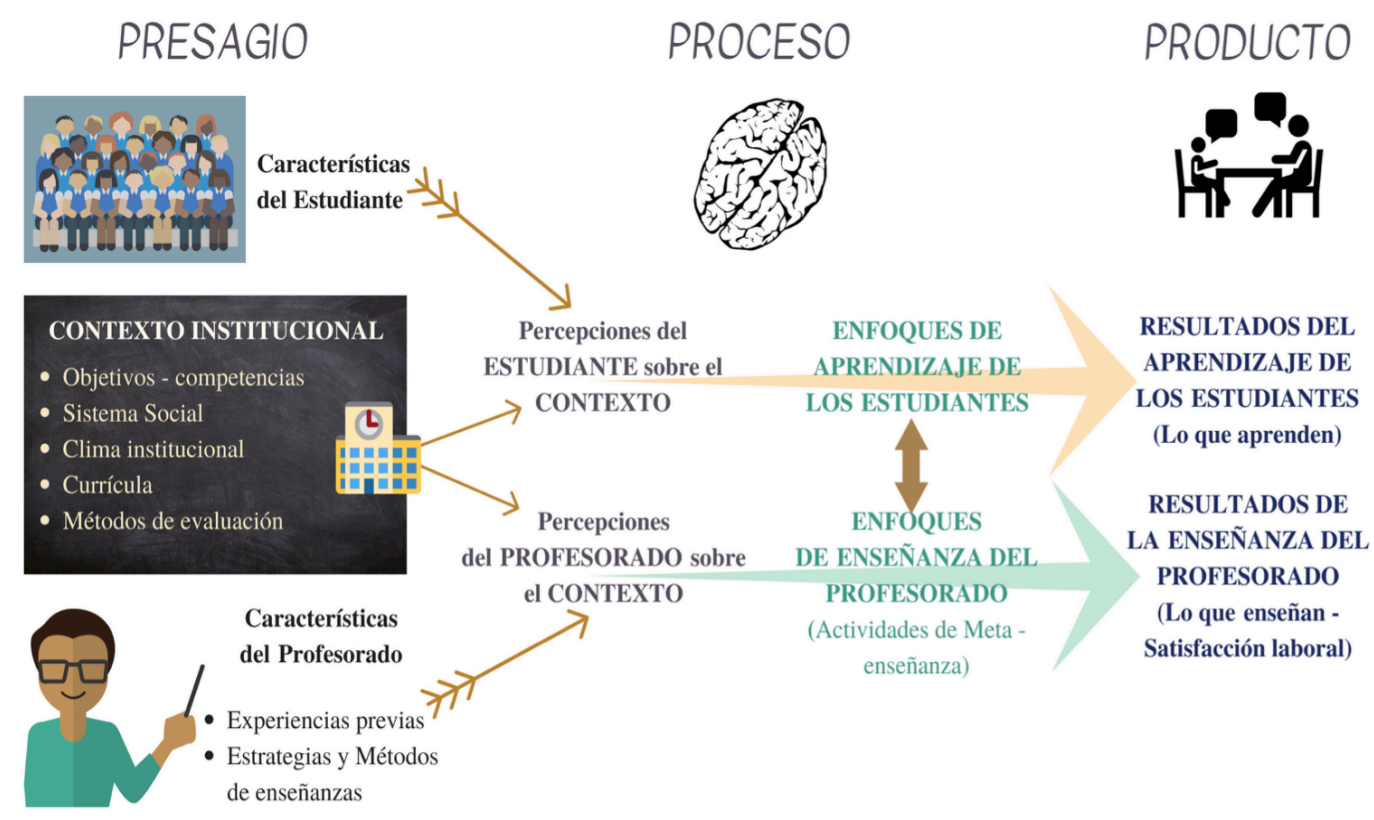


Figura 12: Modelo de enseñanza y aprendizaje de los estudiantes. (Prosser \& Trigwell citado en Hernández - Pina, Maquilón y Monroy 2012, p. 65)

Como se puede apreciar la concepción y enfoque que tiene el profesorado al momento de enseñar influye en el proceso aprendizaje y los resultados que el estudiante pueda lograr. Sin embargo ¿cómo lograr que el profesorado -en la mayoría de los casos mantiene un enfoque centrado en el contenido- pueda adoptar estrategias y enfoques que generen autonomía en el proceso de aprendizaje de los estudiantes, con la finalidad de que puedan responder a las demandas sociales, económicas, ambientales, culturales, entre otras? Porque como ya se ha visto no basta con ser expertos en la materia y dominarla, sino que se necesita de una buena didáctica, profundizar en las metodologías pedagógicas y sobre todo en su sentido de la innovación para lograr comprender al aula en toda su diversidad -conocer y comprender los diversos puntos de vistas que tienen los estudiantes frente a la materia de enseñanza, ya sea por sus capacidades y/o creencias- porque lo más importante es que el profesorado está compuesto por personas para inspirarse, y que ayuden a los estudiantes a ser una mejor versión de sí mismos, sostiene Laguna -Cofundadora y directora del Observatorio Universidad Rey Juan Carlos para el Estudio y Desarrollo de Innovaciones en el Ámbito Educativo- (citado por Díaz, D. 2017)

Y si a ello le sumamos los elementos que desmotivan a los estudiantes que incrementa la deserción escolar prematura como son el desempleo profesional; precarias remuneraciones en los casos de tener un trabajo; las exigencias desmedidas por la obtención de títulos académicos como condicionante a tener un buen puesto de trabajo; la corrupción generalizada; el dinero fácil del tráfico de todo tipo; la caída de la imagen positiva de la democracia y sistemas de justicia y policiales; la igualdad de oportunidades; la violencia normalizada; hace que la premisa de "ir al colegio para tener éxito", se deteriore cada vez más. Y si no hay una respuesta diferente hoy, no habrá motivación ni inspiración para que los estudiantes encuentren un sentido a la experiencia escolar; por ello es necesario una innovación en la educación, en la que docentes y estudiantes se conviertan en agentes de cambio, y juntos puedan revolucionar la educación.

Para esto se necesita reestructurar los planes de estudios que normalmente se centran en asignaturas en las que nadie cuestiona nada, y esto puede ser el principal problema, puesto que sería productivo que los docentes se preguntarán qué deberían saber y poder hacer los estudiantes como producto de su educación; "además de la información propia de cada asignatura se deben tener en cuenta estas ocho competencias básicas que deben ser desarrolladas a lo largo del proceso de enseñanza de manera progresiva, para que tengan éxito" (Robinson y Aronica, 2016, p. 187 - 193):

- Curiosidad: capacidad de hacer preguntas y de explorar cómo funciona el mundo.

- Creatividad: capacidad de generar nuevas ideas y ponerlas en práctica.

- Crítica: capacidad de analizar la información e ideas y elaborar argumentos y juicios razonados "argumentación".

- Comunicación: capacidad de expresar pensamientos y sentimientos con claridad y confianza en una diversidad de medios y formas.

- Colaboración: la capacidad de estudiar, aprender y trabajar constructivamente con otras personas.

- Compasión: capacidad de ponerse en el lugar de otras personas y actuar en consecuencia.

- Calma: capacidad de conectar con la vida emocional interior y desarrollar un sentido de armonía y equilibrio personal "gestión emocional".

- Civismo: capacidad de implicarse activa y constructivamente en la sociedad y participar en los procesos que la sustentan. 
Para que esto funcione, es necesario dejar de concebir al sistema educativo como un sistema industrial y percibirlo como uno orgánico porque es complejo — debido a que está integrado por estudiantes, profesores, familias, directivos, editoriales generando diversidad- y adaptativo porque no están aislado de la vida cotidiana, y por lo tanto deben responder a las necesidades del contexto.

\title{
ARTE COMO INNOVACIÓN METODOLÓGICA
}

Al mencionar la palabra innovación —normalmente se la asocia con la implementación del uso de Tecnologías de Información y Comunicación para el proceso de enseñanza y aprendizaje- debido a que en esta era de la información han facilitado su accesibilidad reduciendo obstáculos como el tiempo y distancia generando una mayor y conexión entre sociedades que anteriormente no sabían de su existencia mutuamente. Sin embargo existen sociedades en el que el acceso a las tecnologías de información y comunicación es nulo o restrictivo, ya sea por el precario avance en tecnología, por condición demográfica, por decisión propia, por normas de estado establecidas, entre otras, idea que ha sido reafirmada durante el Foro Internacional de la UNESCO sobre la TIC y Educación 2030 —como respuesta a los ODS - en la Declaración de Qingdao 2017, sostienen lo siguiente:

\begin{abstract}
Somos conscientes de que siguen existiendo barreras al acceso y el uso equitativos de las TIC que no se superarán únicamente con soluciones basadas en estas tecnologías. Instamos a que en las estrategias nacionales encaminadas a alcanzar los ODS 2030 se incorporen objetivos concretos para lograr la igualdad en el acceso y el uso de las TIC, respaldados por programas específicos que cuenten con una asignación presupuestaria adecuada a fin de equiparar el acceso, las competencias en materia de TIC y el contenido pertinente para las niñas y las mujeres, las personas con discapacidad, los desplazados internos, los grupos social o económicamente desfavorecidos y otros grupos de población insuficientemente atendidos. (...) Con la finalidad de construir Sociedades del conocimiento que deben apoyarse en cuatro pilares: la libertad de expresión, el acceso universal a la información, el respeto a la diversidad cultural y lingüística, y una educación de calidad para todos (UNESCO, 2015).
\end{abstract}

Autores como Imbernón \& Bartolomé (2005) sostienen que la educación de calidad debe basarse en la utilización de habilidades comunicativas, para generar una participación activa reflexiva y crítica ante la sociedad. Si se pretende superar la desigualdad y la exclusión de aquellas sociedades que no tienen acceso a las nuevas tecnologías, primero se debe reflexionar sobre las habilidades y competencias que actualmente se están priorizando y potenciando en los contextos educativos formales e informales y considerar si con ello se viene desarrollando una interpretación de la realidad desde una perspectiva participativa y transformadora; porque al transformar el funcionamiento de la escuela y convertirla en una comunidad de aprendizaje se genera una respuesta igualitaria a la actual transformación social.

Partiendo del concepto de una educación, Integrada, porque se basa en la actuación conjunta de todos los componentes de la comunidad educativa, con la intención de brindar respuestas a las diversas necesidades educativas. Participativa, porque el aprendizaje no termina en las aulas sino que además influye lo que ocurre en el aula, la familia y en la sociedad cultura; y Permanente, porque actualmente recibimos mucha información de manera constante, cuya selección y procesamiento requiere de una formación continuada (Flecha \& Tortajada, 2005); actualmente los medios de comunicación también influyen en el proceso de enseñanza, vivimos en una Hiperrealidad que está transformando la realidad y va generando cambios en nuestra 
manera de entender y comprender los acontecimientos de la vida cotidiana (Acaso, 2017)

La importancia de trabajar como comunidad educativa es porque realmente es mucho más fácil hacerlo de esa manera que en solitario, porque permite tener el apoyo de los demás agentes educativos - otros docentes, directivos, familia, comunidad - y generar espacios para compartir experiencias, directrices e ir generando una cultura de colaboración; que actualmente se necesita para comprender, responder y adaptarnos como sociedad; Kiran Bir Sethi —creadora de Design for Change- menciona que:

Estamos en un momento de incertidumbre, intentando crear o imaginar lo que creemos que sería necesario en educación. Antes no teníamos acceso a la información salvo a través del proceso educativo, pero hoy está cada vez más disponible y hay muchas soluciones para llegar a él. Por eso, el propósito educativo está cambiando. Creo que de lo que se trata es de asegurar que la especie humana llegue a ser precisamente eso, humana y humanitaria. Así que educamos porque queremos un futuro mejor, porque creemos que el mundo puede ser diseñado como un lugar más sostenible, más compasivo y próspero para todos (citado en Díaz, 2017, p. 231).

Es por ello que al referirnos a innovación pedagógica -especialmente en metodología de enseñanza - hacemos referencia al acto de conseguir que todos los estudiantes independientemente de sus capacidades y entornos, logren autonomía en su aprendizaje, ello conlleva a actualizar los proyectos educativos y contextualizarlos de manera individual y colectiva, teniendo en cuenta el propósito del mismo para lograr responder a las preguntas: ¿para qué? y ¿por qué?, lo que nos lleva a considerar como alternativa el uso del arte como una innovación en las metodologías de enseñanza.

Gonzalo (2012), manifiesta que cuando se les enseña a los jóvenes a través de las artes brindan experiencias de aprendizaje auténticas que involucran sus mentes, corazones y cuerpos. Las experiencias de aprendizaje son reales y significativas para ellos. Si bien el aprendizaje en otras disciplinas puede centrarse en el desarrollo de una sola habilidad o talento; las artes recurren múltiples habilidades y destrezas. Idea que es compartida por Coleman (2009) durante su conferencia A call to reinvent liberal arts education, sostuvo:

La participación en las artes, ya sea en artes visuales, danza, música, teatro u otras disciplinas, nutre el desarrollo de las competencias cognitivas, sociales y personales. Lo que permite desarrollar otra forma de abordar la docencia, en la que se produce, no solo un tipo de aprendizaje verdadero, sino un tipo de aprendizaje transformador, que deja de entenderse como un campo de estudio para entenderse como un marco de acción social.

Con esto no se desea menospreciar las prácticas tradicionales, sino demostrar que cuando los estudiantes se involucran en su proceso de aprendizaje, aprenden de una manera significativa y transformadora que influye en su desarrollo y crecimiento personal, lo que se verá reflejado a largo plazo en su participación como ciudadano; y el arte es una herramienta que permite alcanzarlo. De acuerdo con López y Martínez (2006) "el arte fomenta el desbloqueo del proceso creativo y contribuye al proceso del equilibrio intelectual y emocional de las personas, estimulando para que encuentren un mayor sentido a sus emociones y a acciones" (p. 122).

Esta idea del uso del arte como metodología pedagógica, tiene sus antecedentes en Project Zero en la Escuela de Educación de la Universidad de Harvard —proyecto de investigación en la que diseñan diversos programas- fundado en 1967 por Nelson Goodman, desarrollado por Perkins y Gardner desde 1971; cuyo principal objetivo es 
entender y mejorar la educación, la enseñanza, el pensamiento y la creatividad en las artes, y que ha venido siendo desarrollado por diversas maneras y por diversos innovadores en el sistema educativo como Robinson, Gvritz, Xueqin, Amin, Gamwell, Camnitzer, Acaso, Megías, etcétera, su evolución ha venido generando cambios también en sus nominaciones, pasando de "Think Art" de la que salió la consigna "Arte es educación", se re - definió luego como "Arte como educación" dando así origen al término Art Thinking.

Acaso y Megías (2017), consideran al Arte como <<Prácticas Productoras de Conocimiento $>$ caracterizándose por ser una práctica cultural -en la que el conocimiento: actual y tradicional es el elemento central-generado a través de una experiencia de saberes que nos conducen al aprendizaje considerándolo como un motor de cambio social y práctica reflexiva y cuestionadora - en la que se fomente el cuestionamiento crítico con la finalidad de interrogar a la realidad-generando de esa manera experiencias de aprendizaje largas, reflexivas y complejas; en la que el principal elemento sea la creatividad y autoexpresión de los participantes fomentando la libertad de pensamiento y autoestima. Por que lo principal es "desarrollar una práctica cultural autónoma de producción de conocimientos y así poder educar a la institución, con la finalidad de que logren comprender que su tarea principal es deshacer la brecha entre educación y arte" (p. 101).

Desde esta perspectiva se pretende abordar y profundizar el presente estudio, enfocándose en el uso del arte como metodología de enseñanza con la finalidad de instaurar, fortalecer y potenciar: el pensamiento divergente que es producto del pensamiento crítico y pensamiento creativo; la gestión emocional y la identidad cultural, con la finalidad de lograr una autonomía en el proceso de enseñanza y aprendizaje de los estudiantes, respondiendo de manera contextualizada a las necesidades educativas de la comunidad educativa -estudiantes, profesorado y padres de familia - generando una calidad educativa en las instituciones educativas formales e informales.

\section{PENSAMIENTO DIVERGENTE = PENSAMIENTO CRÍTICO + CREATIVIDAD}

Como se menciona anteriormente, en esta era de la información, en la que la producción del conocimiento se da de manera constante y que además sufrimos de una contaminación informática, porque el acceso a diversas informaciones solo se encuentran a un click de distancia; es necesario aprender a gestionarla, por lo que es importante adoptar nuevas maneras de procesar la información - pensamiento- y lograr activar la conciencia crítica; Meirieu (2008) "pasemos de ser un objeto en construcción a un sujeto que se construye" (p. 73). Es prioridad de las instituciones y agentes educativos que el pensamiento crítico se convierta en un hábito tan importante como el de cepillarse los dientes (Acaso y Megías 2017).

Del mismo modo Freire (2017), nos da a conocer las dos razones por las que la forma de entender la educación -actualmente sostenida - se viene haciendo cada vez más disfuncional en nuestra sociedad. La primera, es que la tecnología digital es capaz nos ofrece de forma más rápida, barata y con niveles de calidad al menos similares y/o superiores, lo que antes nos ofrecían las aulas, profesores e instituciones educativas. Y la segunda es porque la educación convencional no aborda las verdaderas necesidades de los ciudadanos. Fortaleciendo la necesidad de cultivar un pensamiento creativo en las aulas que puedan transformar los conocimientos y crear nuevos aprendizajes - formas de aprender- porque la "creatividad" es algo que las máquinas no podrán suplantar. De La Torre (citado en Parra 2016, p. 43) en sus trabajos e investigaciones realizadas resalta siete principios de la creatividad, que dan a conocer la complejidad que tiene en la que se conjugan dimensiones del ser y sus productos culturales, relacionado directamente con la educación: 
- Es intrínsecamente humana y al igual que la educación, es un atributo de los seres racionales.

- Está asociada a la intencionalidad y direccionalidad.

- Tiene un carácter transformador, puesto que contribuye activamente a las estructuras mentales y en base a ellas se actúa sobre los diversos entornos.

- Existe relación entre los procesos productivos y procesos comunicativos.

- La originalidad o novedad es el atributo principal.

- Todo acto creativo está sujeto a la ética, siendo este apropiado a los valores de las respectivas comunidades receptoras.

- Todo acto creativo está ligado a las emociones, puesto que confluyen pensamientos y sentimientos.

El pensamiento creativo es una expresión de la capacidad mental, por lo que su fortalecimiento dentro de las aulas resulta ser un elemento primordial para lograr aprendizajes significativos. Autores como Habermas, De los Ríos y Gardner (citado por Acaso 2017) y diversos estudios de neurociencia - especialmente enfocados en neuroeducación- sostienen que el pensamiento divergente es una estrategia para crear conocimientos y que además despierta el deseo de pensar; estudios que tienen su origen en los años 50 con los estudios realizados por Gilford y posteriormente por Barron (citado por Parra 2016), en las que establecieron factores asociados a la inteligencia que son característicos de la conducta creativa; y en la que manifiestan que los conocimientos y memorización tienen poca relación con la creatividad y por el contrario el pensamiento divergente entendido como - contemplar diversas posibilidades a la solución de un problema- está altamente relacionado con la creatividad, véase Figura 13.

\section{CONOCIMIENTOS}
Capacidad de comprender datos
Tienen menor relación

con la creatividad

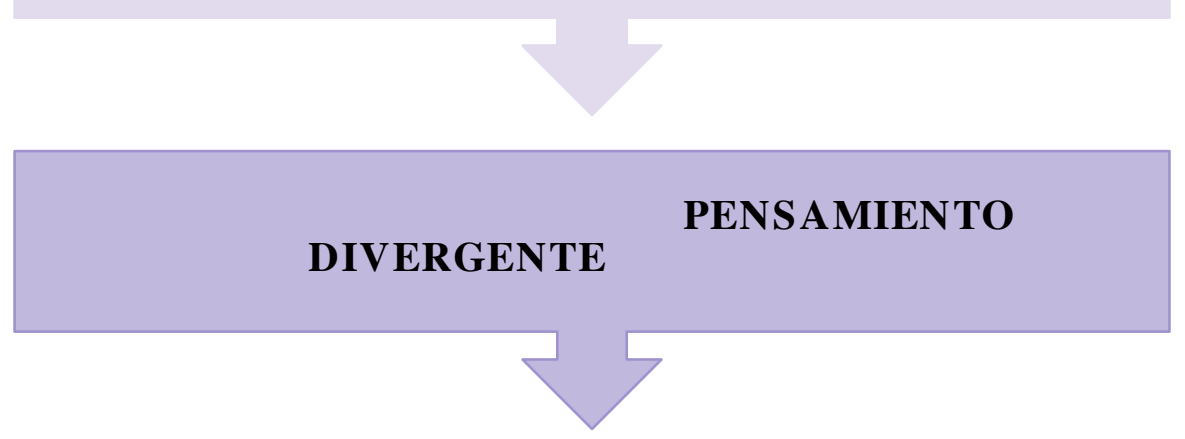

CONVERGENTE

\section{PENSAMIENTO}

Capacidad de establecer un orden entre Factor de difícil

Figura 13: Factores asociados a la inteligencia característicos de la conducta creativa. (Barron, en Parra 2016, p. 61)

Lo que nos demuestra que el pensamiento divergente fomenta la creatividad y al mismo tiempo se caracteriza por plantear diversas alternativas de solución frente a una problemática lo que ayuda a los estudiantes ejercitar su punto de vista crítico, su creatividad y que esa curiosidad innata genere una implicación con su aprendizaje tanto en el ámbito académico como personal, a lo que Bona (2016) manifiesta: 
Las puertas de la escuela han de estar abiertas no solo para que entren los niños/as, sino para que sus ideas salgan y transformen al mundo; porque están compuestos de imaginación, ilusión, creatividad y curiosidad y es algo muy raro e incómodo hacer que se comporten como un seudoadulto (...) cuando también son habitantes del presente y como tal hay que darles la opción de actuar y opinar (p. 111 y p. 196).

Parra (2016), considera que las actividades artísticas pueden conseguir estimular y revelar capacidades de la creatividad personal. Puesto que al convertirse en creadores - dejando de lado la actitud pasiva basada en recibir información- éste se convertirá en el detonante para el reconocimiento y valor de sí mismos por sus logros. Durante las diversas investigaciones sobre creatividad, Robinson (2016), sostiene que $<<$ la creatividad es el proceso de tener ideas originales que son de utilidad y para ello se necesita de la imaginación:asociado al pensamiento divergente que permite generar nuevas ideas e innovación: poner en práctica las nuevas ideas $>>$, también requiere valorar la calidad del proceso para poder cultivar la pasión por descubrir a través del aprendizaje. Desarrollar esta "pasión por aprender", debe basarse en tres creencias fundamentales, que son difíciles de ponerlas en práctica pero que son realmente gratificantes porque ayudan en la transformación cultural de la educación:

- El principal objetivo de educar debe ser preparar a los estudiantes para la vida después de la escuela ayudándolos a desarrollar recursos mentales, emocionales, sociales y estratégicos que les permita hacer frente a los desafíos, incertidumbre y complejidad de la existencia.

- Es fundamental ayudarlos a descubrir en que les encantaría destacar encontrar su vocación - y de esa manera fortalecer su voluntad, ayudarlos a potenciar sus habilidades y competencias para llevarlo a cabo.

- Así como también es posible desarrollar la confianza, capacidades y la pasión de cada uno porque la inteligencia práctica: capacidad de comprender el entorno y utilizar ese conocimiento para determinar la mejor manera de conseguir unos objetivos concretos, mejora sustancialmente si se la estimula.

Del mismo modo el autor, manifiesta la importancia de conocer "cuál es la naturaleza propia del aprendizaje, qué métodos de enseñanza son los mejores para los estudiantes y de qué opciones - recursos se dispone, porque si las escuelas y políticas educativas se equivocan en estas cuestiones, todo lo demás es mero ruido de fondo" (p. 113).

\section{GESTIÓN EMOCIONAL}

Para lograr que a través de la educación los estudiantes puedan ejercer una transformación cultural en el mundo, es necesario ayudarlos a desarrollar sus recursos mentales, pero también los emocionales y sociales. (Robinson y Arinoca, 2016). La comunidad educativa — profesorado y madres/padres de familia - están concentrados en cambiar a los niños, niñas y adolescentes cuando en realidad lo que se tiene que hacer es cambiar la perspectiva que se tiene de ellos; por eso resulta fundamental aprender a escuchar antes de enseñar e invertir tiempo en aspectos que normalmente no están asociados a los buenos resultados académicos, como lo son el respeto, empatía, sensibilidad, tolerancia. "¿Por qué un don importante, como es el don de la comunicación sigue sin estimularse en las escuelas?" (Bona, 2016, p. 108).

La tensión emocional de la sociedad en general, hace que la gestión emocional no sea considerada como un elemento principal, o si es que lo hacen sea durante la hora de tutoría y que en muchas ocasiones es la hora adecuada para reforzar matemática, física, etcétera. Sin embargo el ser humano es un ser social y requiere de la interacción con los otros, la cual empieza con la comunicación -capacidad de expresar: ideas, pensamientos, sentimientos utilizando la voz, gestos, imágenes y/o símbolos- que empieza, en la mayoría de los casos con un balbuceo, luego se 
emiten algunas palabras y para cuando vamos a la escuela -que es el primer entorno social fuera de nuestras familias - nos enseñar a hablar "correctamente", leer y escribir; sin embargo es allí donde la comunicación se reduce a expresarnos respetando la gramática de un idioma, dejando de lado nuestra capacidad de poder dar nuestra opinión frente a las tediosas fórmulas de matemática, expresar nuestros sentimientos antes un hecho histórico, saber decirle que no frente al acoso escolar en la hora del patio, a relacionarnos entre nosotros mismos y respetar las opiniones de los demás, a poder hacernos responsables de nuestro aprendizaje pero no como una obligación sino convertirla en una pasión por aprender, etc.

Ya vimos que dentro de las Top ten skills del World Economic Forum realizado en el 2016, se encuentra la Inteligencia Emocional, porque realmente no importa cuántos títulos académicos puedas obtener o las especialidades que puedas realizar, si no eres capaz de respetar las ideas, opiniones y decisiones de los demás; si es que eres preso de tu ansiedad y no logras afrontar las diversas adversidades que se puedan presentar; si no logras alcanzar tus metas ni tu propia felicidad, etcétera; porque todo ello repercutirá en los aspectos de tu vida familiar, social, laboral y académica; y la escuela debe brindar herramientas y estrategias necesarias para hacer frente a dichas realidades; frente a ello Bona (2016) menciona "(...) entre esos niños está el futuro marido que sabrá respetar a su pareja o la persona que sabrá dar un paso adelante ante la injusticias e intentar cambiar las cosas (...) más allá de los estándares y logros, no olviden que lo que tenemos enfrente, son los ojos de un niño/a que tiene sueños" (p. 253 y p. 259).

Los diversos estudios e investigaciones en el ámbito de la psicología del desarrollo y neurociencias, sustentan que las emociones en el proceso de enseñanza y aprendizaje son fundamentales, no sólo para fortalecer la gestión emocional, sino también dentro del propio proceso, en el que influyen factores sociales como: la imitación, atención compartida-hace referencia al acto de dos o más personas mirando el mismo objeto o evento- y la comprensión empática, lo que da como resultado lo que Mora (2016) considera que la relación entre "cognición - emoción sea un binomio indisoluble que nos lleva a concebir que no hay razón sin emoción" (p. 42). Ello se puede evidenciar en algunas experiencias en las profesores con un alto dominio en su materia pero que no logró establecer un vínculo de empatía e interacción con sus estudiantes, pueden fracasar en el proceso, así como también existen profesores sin tener un dominio de conocimientos, pueden inspirar y motivar a sus estudiantes para que aprendan, debido a que tiene mucha empatía e implicación con ellos. Actualmente se habla mucho sobre "el apagón emocional que ocurre en mucho niños y niñas en algún momento de su periodo escolar y que se ha relacionado con el hecho de vivir en una sociedad estresada" (p. 69), este patrón no es más que el reflejo de la necesidad de atender con igual importancia las habilidades sociopersonales que permitan un mejor rendimiento en lo académico pero también en el ámbito social y personal. Apreciaciones que son compartidas por Gutiérrez y Horna (citado en Díaz 2016, p. 51):

El ser humano es ante todo un ser emocional: las emociones condicionan cómo y qué aprendemos, además de ser la base de la convivencia social y un elemento clave en la felicidad de una persona. La educación no puede seguir descuidando esto, y es necesario que los docentes tengan una formación adecuada en este sentido también, no como formación teórica sino desde la práctica cotidiana.

Otro de los aporte de la Neurociencias es que están ayudando de desmontar alguno mitos sobre los procesos cognitivos, y uno de ellos hace referencia a la atención puesto que no puede mantenerse durante 50 minutos seguidos, por eso Mora (2016) recomienda que "se debe romper con el actual formato de las sesiones clases, porque es mucho más productivo asistir a 50 clases de 10 minutos que a 10 clases de 50 minutos"; como se sabe que llevarlo a la práctica es sumamente difícil, se aconseja a los profesores el uso de elementos disruptores - puede ser: una anécdota relacionado al tema, una 
pregunta, un vídeo, una reflexión, etc. que plantee un tema distinto pero que guarde relación con objetivo principal de la sesión - por ejemplo:

- Al hablar sobre la segunda guerra mundial, pueden mencionar que cuando cuando Hitler visitó París, los franceses cortaron los cables de los ascensores de la Torre Eiffel, por lo que si que si él quería visitar la parte superior, tendría que subir a pie

- Durante el desarrollo del tema de los elementos químicos, mencionar que el Fósforo $(P)$ fue descubierto cómo un experimento de la orina de su creador, Henning Brand, y que tiene ese nombre porque la sustancia obtenida brillaba en la oscuridad, por lo que se eligió el vocablo griego que significa "portador de la luz".

Cómo ya vimos las emociones despiertan y mantienen la curiosidad e interés por descubrir, lo que generará una mejor predisposición para "almacenar la información y recordarla de una forma más efectiva. (...) el educador debe ser consciente de este mecanismo esencial - emoción - como vehículo de conocimiento a través de sus palabras, logrando generar la atención del que escucha y aprende" (Mora 2016, p. 66). Por ello el arte es considerado el aliado estratégico; Parra (2016) considera "al arte como el medio idóneo para desarrollar la expresión personal y de comunicación con uno mismo y con los demás, porque tiene el poder de reflejar y dejar aflorar los sentimientos, pensamientos y emociones" (p. 87). De esta manera, contribuye al desarrollo de competencias intelectuales y creativas, fortalece la capacidad de expresarse y relacionarse, participando activa y críticamente en los diferentes escenarios haciendo posible el reconocimiento de que existe la diversidad cultural.

\section{IDENTIDAD CULTURAL}

La diversidad cultural viene ser la suma de todas identidades que puedan estar presentes en una sociedad; comprendiendo como identidad "aquello que los individuos asumen como lo que los identifica, ello implica la posibilidad que durante el proceso de aprendizaje y socialización, concienticen su yo al tiempo que lo hacen respecto de su grupo" como lo define Freire (citado en Brito 2008, p. 36). La universalización de la escolaridad ha sido provocado por una serie experiencias y subjetividades individuales, que influencian en la percepción de una/o misma/o y por ende en la identidad personal, como respuestas a las preguntas: qué es, quién cree que es y cómo se siente, tienen mucho que ver con la educación que recibimos; Giddens (1995) manifiesta que "el yo del varón y la mujer modernos escolarizados se espera que sea un yo reflexivo" (p. 17) que sea consciente de su presente pero también de su pasado identidad cultural.

La educación es una de las principales vías que tienen las comunidades para transmitir sus valores, costumbres y tradiciones de una generación a otra, y además también es una herramienta que nos permite proteger la influencia externa sobre ella, y al mismo tiempo para comprender, tolerar y respetar la diversidad cultural —que gracias a la globalización se tiene mayor accesibilidad- la educación se nutre de las personas y culturas y por tanto tiene la capacidad de generar sociedades mejores, por ello es relevante analizar la continuidad de "las imágenes" del pasado, del presente y las proyecciones que se tienen sobre el futuro:

Lo que nos rige son las imágenes del pasado, las cuales, están en alto grado estructuradas y son muy selectivas. Esas imágenes y construcciones simbólicas del pasado están impresas en nuestra sensibilidad, casi de la misma manera que la información genética. Cada era verifica su sentido de identidad, de regresión o de nueva realización teniendo como telón de fondo ese pasado (Steiner, citado en Gimeno, p. 17). 
La educación, como lo mencionamos anteriormente debe considerarse como un instrumento para generar la libertad y autonomía, fortaleciendo la construcción de la personalidad y de sus capacidades a través de la asimilación de su cultura, considerándola como Freire (1999) "la cultura es el resultado de la acción creadora del hombre, como resultado de su trabajo" (p. 117). El proceso educativo no sólo debe considerarse como un espacio de aprendizaje cognitivo, sino que también debe propiciar una experiencia interactiva con su cultura, en la que los estudiantes puedan percibir y transformar críticamente su entorno social. Si se fomenta una articulación de los saberes - conocimientos ancestrales producto de la cultura de una sociedad-y vivencias culturales, con la con las prácticas de la cotidianidad se producirá un aprendizaje diverso y comprometido con las diversas problemáticas y realidades; porque con el actual acceso de las nuevas tecnologías de las comunicaciones e información se tiene acceso a otros saberes, culturas, identidades lo que genera un reto mayor, para poder generar vínculos y lazos con otros referentes y prácticas culturales; buscando generar un sentido de comunidad no sólo en nuestra sociedad sino también con las demás sociedades, ello hará que se proporcione un aprendizaje que fomente una capacidad de análisis y valoración de las diferentes realidades de nuestro contexto, que servirán como instrumentos fundamentales para combatir prejuicios y estereotipos posibilitando la diversidad basados en el respeto e igualdad.

Pero este cambio depende también del grado de implicación que se pueda fomentar en la sociedad -considerándolo como agente educativo- puesto que como se mencionó anteriormente las "ciudades creativas", buscan proporcionar a sus ciudadanos las condiciones adecuadas para que fluya la creatividad, con el fin de generar proyectos que beneficien a su entorno; pero ello requiere generar espacios de colaboración, participación, establecer redes y tener la capacidad de escuchar a los ciudadanos -estudiantes, profesorado, padres y madres de familia, etcétera- de todas las edades y condiciones; consolidando de esa manera una cultura hacia la innovación, y que al mismo tiempo ayude a fortalecer la identidad sociocultural en los estudiantes, véase Figura 14 (Ramos y López, 2013).

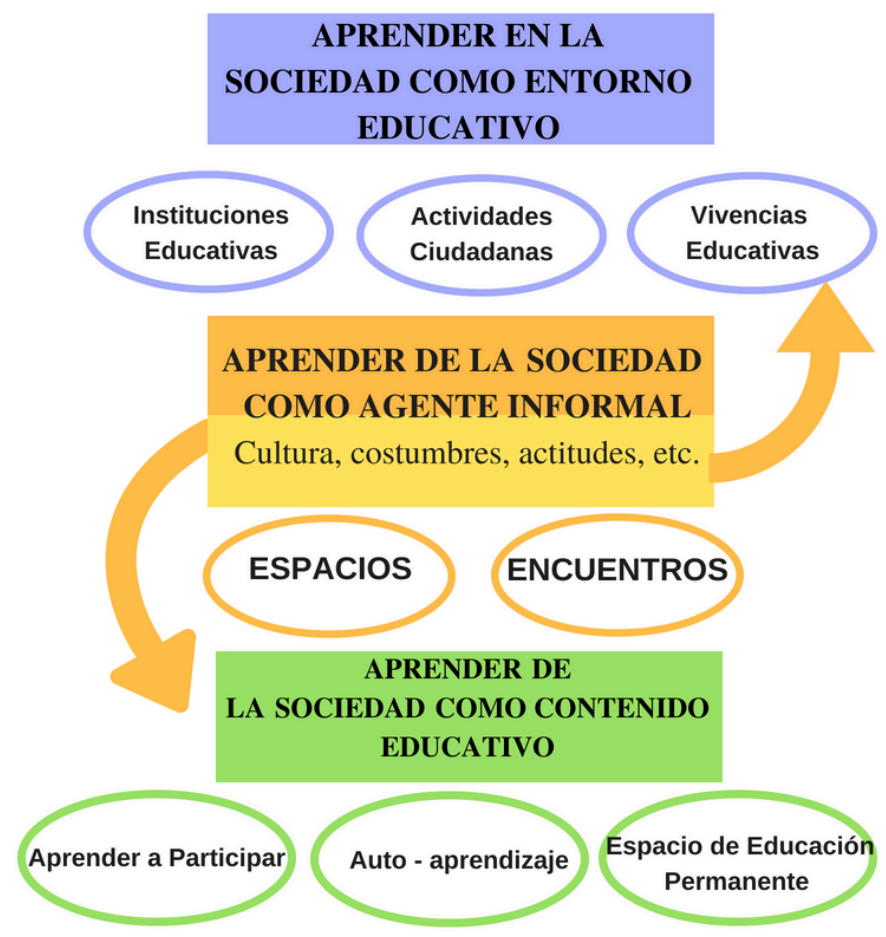

Figura 14: Sociedad educadora y creativa para el fomento de la identidad sociocultural. Elaboración Propia. 
La formación de la identidad personal, depende en buena medida de cómo creemos que los demás nos ven desde los diversos aspectos es por ello que realizar un trabajo conjunto de la propia historia personal con las experiencias sociales, es de suma importancia porque la propia sociedad y cultura influyen en la formación de la identidad de los estudiantes; y para ello la actividad artística es una vía de conexión en este proceso.

Sabemos que el arte desde siempre ha sido una vía de expresión para las sociedades en las que se consideraban como formas de producción: pintura, música, voz, escritura, danza, teatro, poesía, cuentos, etc. en la que culturas emitían un recorrido simbólico tomando conciencia de sí mismas, revelando su esencia, parámetros, valores, costumbres, creencias y cualidades que forman parte de su identidad como sociedad y cultura; la estrecha relación entre Arte y Cultura, están fundados dentro de un espacio definido, un contexto histórico y relaciones sociales características de la comunidad a la que pertenecen, y en la que el ser humano es partícipe central del desarrollo de ambos. Allí nace la importancia de reforzar como parte del proceso de enseñanza - aprendizaje la autoestima de los estudiantes, porque las personas que se sienten bien consigo mismas - y ello implica un adecuado autoconcepto- suelen tener relaciones interpersonales saludables, ser capaces de afrontar y resolver con seguridad los retos y responsabilidades que ésta les plantea, como explica Tranche (1995, p. 45):

(...) la mayoría de los/las expertos en el tema entiende que las personas con un autoconcepto ajustado y positivo son más capaces de actuar de forma independiente, elegir y tomar decisiones, interactuar con los demás, afrontar nuevos retos, asumir responsabilidades, contradicciones o fracasos...; en definitiva, están mejor preparadas para participar de manera responsable en las distintas actividades e instancias sociales y alcanzar un mayor nivel de felicidad tanto propia como ajena. Parece indudable, pues la incidencia que tiene el autoconcepto en la organización mental de los individuos y en el control y dirección de sus conductas y realizaciones.

La contribución más importante del arte es dar identidad a un país o una región porque genera un sentido de pertenencia y comunidad haciéndolas más inclusivas; y todo ello se logra si es que en el ámbito de la educación formal e informal -aulas, escuelas, asociaciones, familias, institutos, etcétera - se empieza a utilizar metodologías reflexivas, comprometidas no solo con el aspecto académico de los estudiantes sino también con los aspectos socioemocionales y culturales, convirtiendo la práctica en una práctica autónoma de conocimiento que potencian la voz y los saberes, la participación ciudadana.

\section{EXPERIENCIA PERSONAL}

Durante mi primer año como profesora, me asignaron el curso de Historia, Geografía y Ciudadanía a un grupo de estudiantes pertenecientes al tercer grado de secundaria, que equivale a tercero de la ESO en el contexto educativo español, a lo que, me planteé la siguiente pregunta: ¿Qué es lo que me enseñaron en Historia?, e inmediatamente recordé lo aburrido y tedioso que se hacían las horas cuando la profesora ingresaba al aula para repetirnos nombres y fechas que teníamos que memorizar para aprobar el examen; realmente no había aprendido nada de Historia ni mucho menos ejercía mi Ciudadanía y por Geografía aprendía más a través de las enciclopedias que tenía en casa, y si no fuese por mi curiosidad y viajes realizados, actualmente me consideraría una inepta en ese sentido; y es allí cuando decidí que no quería convertirme en esa "profesora que obligaba a sus estudiantes a atragantarse con fechas, ciudades y personajes"; sino al contrario quería despertar pasión en ellos, y motivación por conocer sobre nuestros ancestros, las culturas que estuvieron antes 
de nosotros, lo que sucedía y sucede en el mundo, y que ellos mismos se hagan reflexiones sobre la evolución del hombre y puedan ejercer una participación ciudadana con criticidad, reflexión y autonomía.

Pero ¿Cómo iba a lograr eso?, si la asignatura en sí suele tener la etiqueta de ser "aburrida y tediosa"; fue allí donde descubrí al ARTE —en todas sus formas: teatro, cine, pintura, cómics, música, etcétera - como un gran aliado; a través de teatro mis estudiantes asumieron las funciones, responsabilidades y decisiones de las heroínas y héroes - de manera relativa y reflexiva - ante los acontecimientos históricos, asimismo ellos iban identificando sus habilidades y destrezas, puesto que algunos tenían la facilidad de asumir el papel y dramatizar, otros preferían realizar el proceso de investigación de los hechos, etcétera.

A través de las canciones de diversos artistas de las distintas épocas se iba analizando la influencia sociocultural y política que se encontraban en las letras y de esa manera ser conscientes de lo que el artista nos quería transmitir, generando debates en las que cada uno tenía una voz y asumen una postura frente a ellas; además elaboraban una canción como respuesta en la que volcaban sus pensamientos, sentimientos y reflexiones generadas. Por otra parte se realizaban análisis reflexivos de las noticias de los diversos diarios, en los que ellos mismos se daban cuenta del manejo de la información, la omisión de la verdad, y sobre la falta de participación ciudadana; lo que generó en ellos una frustración por ser "solamente estudiantes" pero que supieron canalizar haciendo llegar su opinión con su aprobación o rechazo y alternativas de solución frente a las problemáticas sociales; a través de cartas, fanzines, cómics, infografías, columnas de opinión, etcétera dirigidas a empresas gubernamentales y privadas; véase las Figuras 15, 16, 17, 18 y 19 que son algunas imágenes de las creaciones producidas por los estudiantes durante todo el periodo académico.

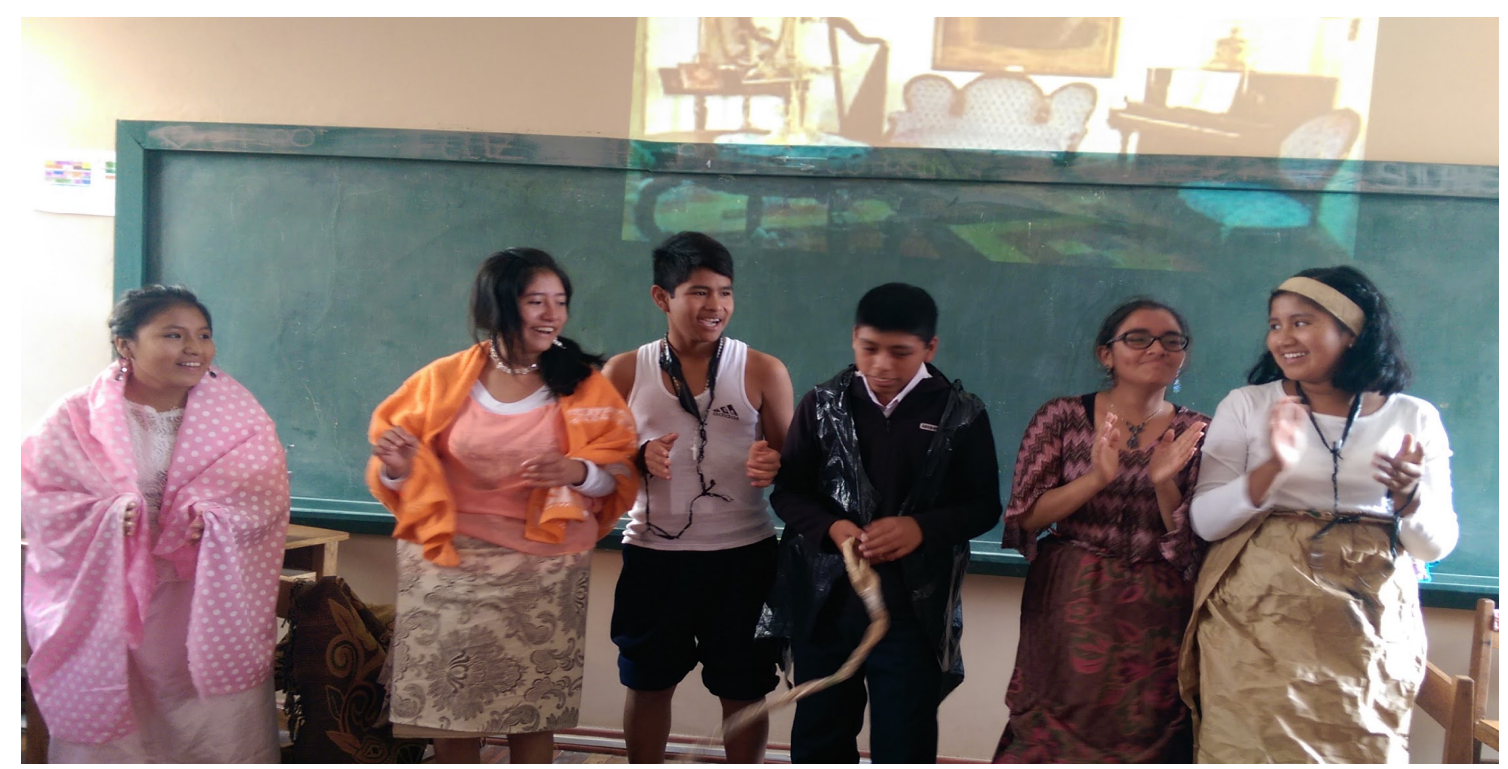

Figura 15: Dramatización de la época colonial en la sociedad peruana. 


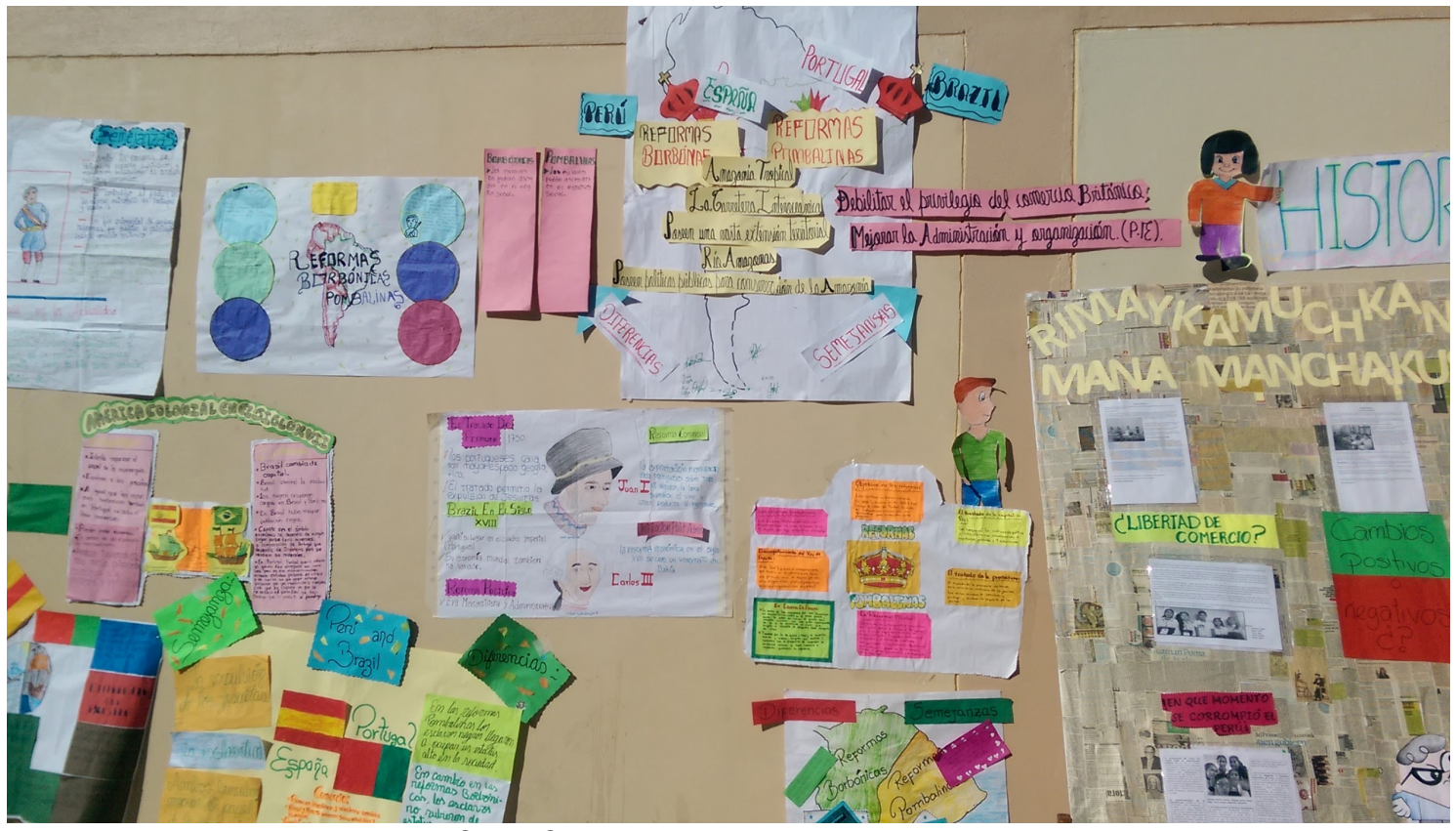

Figura 16: Exposición de infografías y columnas de opinión en el pasillo del colegio.

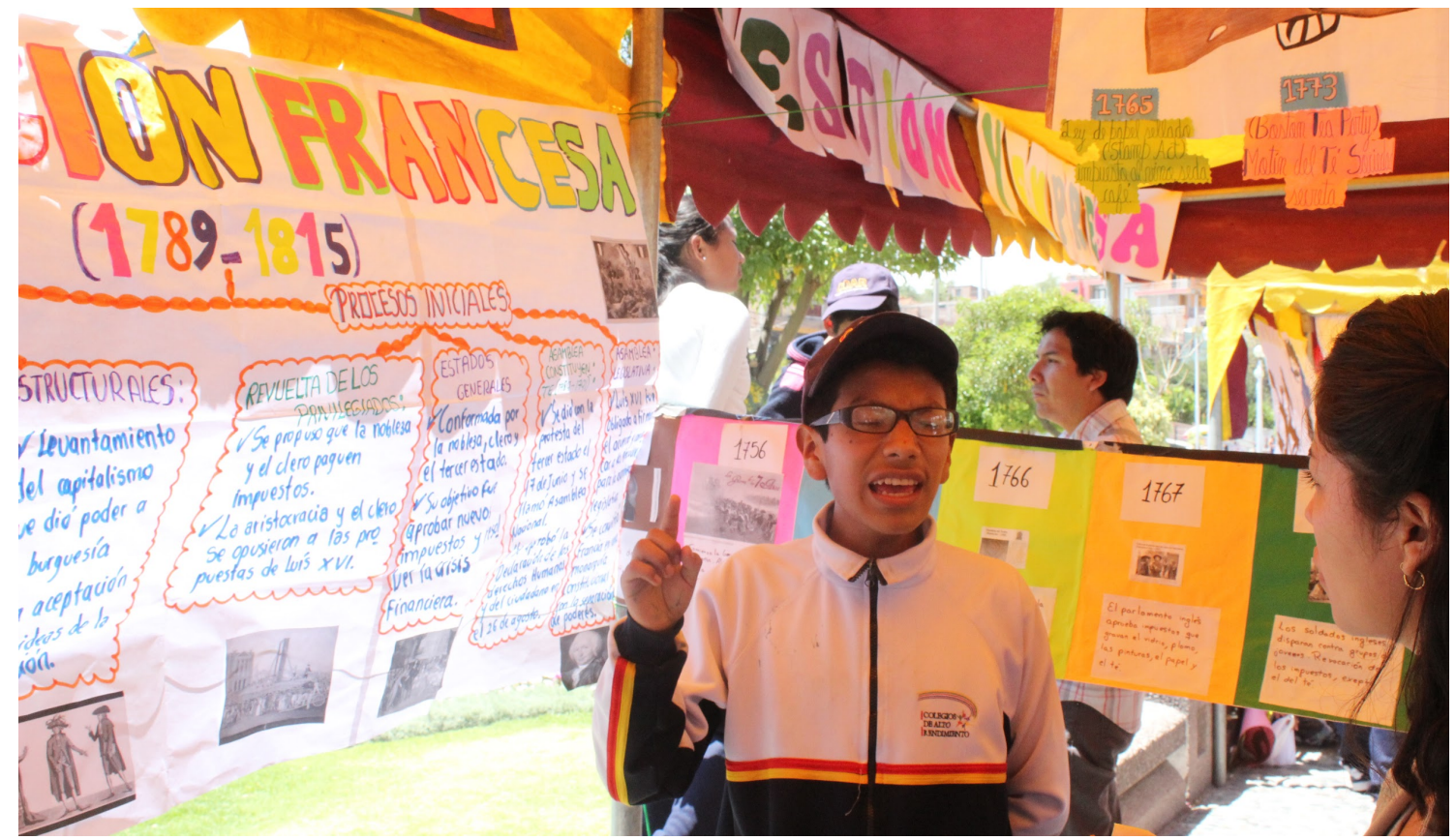

Figura 17: Día del logro - Huamanga. 


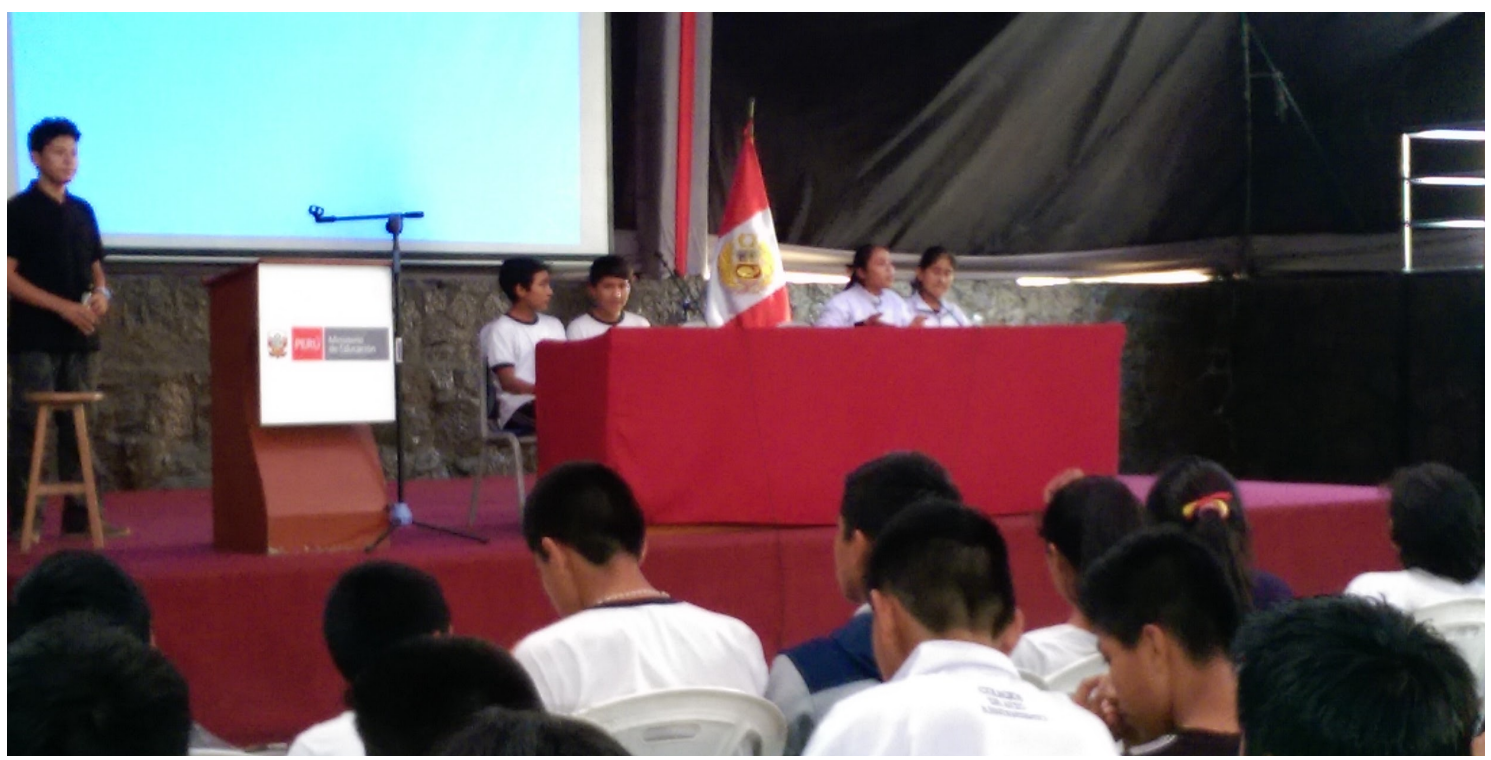

Figura 18: Mesa de Debate en las instalaciones del Municipio - Huamanga sobre la situación actual de la minería en la provincia.

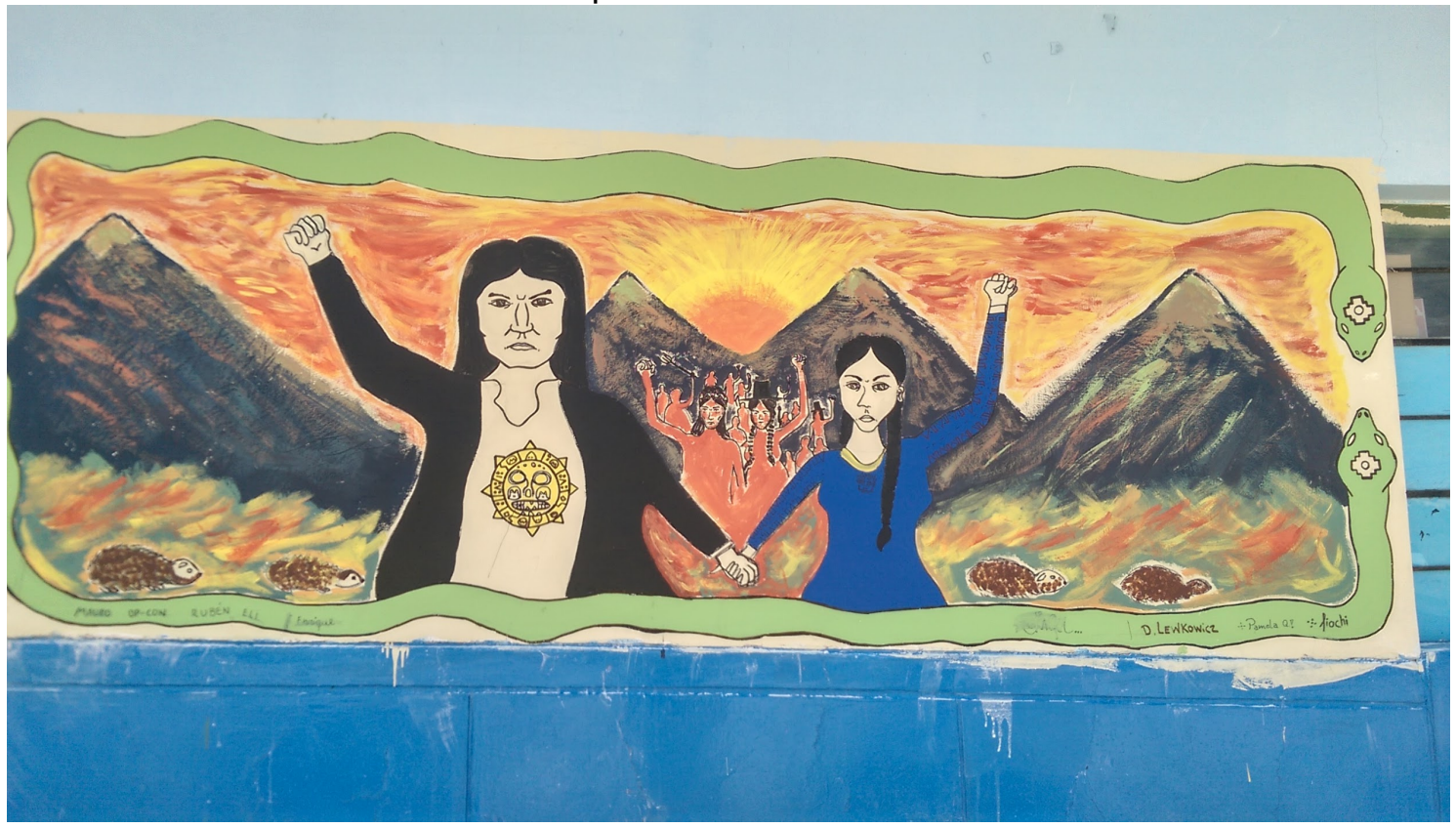

Figura 19: Mural realizado con estudiantes del distrito de Tungasuca como revalorización del acto heroico de Túpac Amaru y Micaela Bastidas.

El desarrollo de las actividades respetaron los lineamientos generales de la currícula escolar -en las que se consideraban desarrollar y fomentar cuatro principales competencias y capacidades, véase Tabla 2- pero fueron contextualizadas a las necesidades e intereses de los estudiantes; la metodología que utilizaba -el Artepromovía canalizar sus propuestas producto de la reflexión, implicación e interés por los acontecimientos tanto históricos como actuales, en la que desarrollaron su pensamiento crítico, creatividad para generar una participación ciudadana que va más allá de las aulas, puesto que involucraron a sus otros compañeros de otras aulas, al equipo directivo, a otros profesores, a otras instituciones educativas y a la sociedad de Huamanga - Ayacucho desarrollando actividades de concientización y reflexión, en la que sintieron que su voz estaba siendo escuchada, generando en ellos el sentimiento de aprobación, satisfacción y éxito reconocido por los diversos agentes; lo que llevó a reforzar su autoconcepto y autoestima.; además se vio reflejado en su rendimiento académico, para ello véase la Figura 20 en la que se visualizan los promedios 
adquiridos durante los Bimestres desarrollados a lo largo del año académico.

Tabla 2: Matriz de Competencias, Capacidades y Criterios de Evaluación de la asignatura Historia, Ciudadanía y Geografía

\section{Competencias}

Conocimiento y comprensión de los procesos históricos y fenómenos geográficos

Desarrollo del pensamiento crítico de los procesos históricos y actuales

Desarrollo de habilidades de investigación

Reflexión y participación ciudadana

\section{Capacidades} y comprende los procesos históricos y fenómenos geográficos.

Analiza y construye argumentos haciendo uso del pensamiento crítico en el conocimiento de los procesos históricos y actuales.

Desarrolla habilidades de investigación para el alcance de un conocimiento profundo en relación a los procesos históricos, situaciones de ciudadanía y fenómenos geográficos.

Toma conciencia reflexiva y ética sobre la responsabilidad del ejercicio de la participación ciudadana a nivel local, regional, nacional y mundial.

Elaborado por Ministerio de Educación del Perú, 2015.

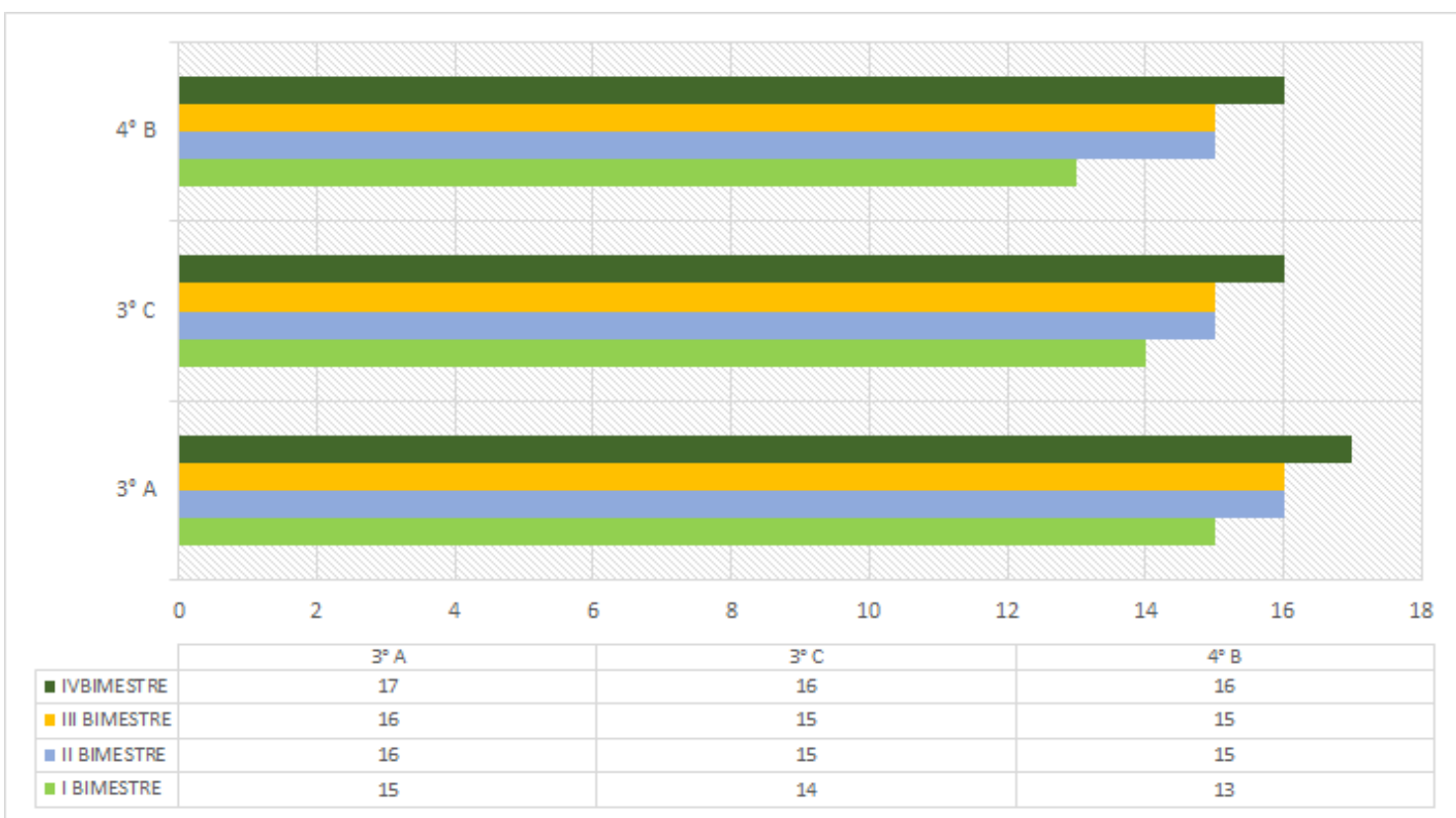

Figura 20: Promedios obtenidos a lo largo del curso académico 2015. Elaboración propia.

Esta experiencia me convenció de que realmente si queremos generar en nuestros estudiantes un aprendizaje que trascienda en ellos como seres humanos, tenemos que "mantenerlos en efervescencia" y ello se consigue a través de metodologías de enseñanza que los mantengan activos y reflexivos durante toda la clase, que los motive e inspire a generar cambios no sólo en beneficio propio sino también para la comunidad. Que los conviertan en protagonistas de su proceso de aprendizaje y sean ellos generadores de su conocimiento asumiendo la responsabilidad e implicación que requiere un aprendizaje significativo, porque de esa manera podrán extrapolar sus 
conocimientos a los diversos ámbitos en su día a día. Por este motivo considero que el ARTE como metodología de enseñanza funciona de manera efectiva e integradora durante el proceso de enseñanza - aprendizaje de cualquier asignatura, permitiendo al estudiante expresar sus pensamiento y sentimientos, convertirlos en creadores, y sobre todo generando la reflexión durante todo el proceso educativo.

\section{Objetivos}

El objetivo general de este estudio es conocer el enfoque de enseñanza que predomina en el profesorado de diversos contextos socioculturales; los objetivos específicos son:

- Conocer el grado de coherencia entre las intenciones y estrategias dentro de cada enfoque y entre enfoques.

- Identificar si, el enfoque de enseñanza predominante que adopta el profesorado propicia una actitud de mayor aceptación a la innovación en metodología de enseñanza.

- Conocer la importancia del arte como metodología de enseñanza en la educación formal.

- Conocer el grado de aceptación de la página web elaborada.

\section{Métodos}

El presente estudio de carácter exploratorio previo a una investigación, se planteó la utilización de una metodología mixta en la que se hiciera el análisis de la relación entre las variables: enfoques de enseñanza que asume el profesorado; actitud hacia la innovación metodológica; el arte como metodología de enseñanza tanto desde aspectos cuantitativos, utilizando el programa estadístico SPSS para analizar los resultados obtenidos del Cuestionario de Enfoques de Enseñanza; y desde el aspecto cualitativo orientado por la corriente sociológica, la Etnometodología que "sostiene que la relación entre actor y situación no se basa en los contenidos culturales, ni en las reglas, sino que nacerá a partir de los procesos de interpretación, buscando así enriquecer la discusión con los datos obtenidos" Colas (1998). Finalmente se realiza un análisis de frecuencia del número de visitas y suscripciones de la página web elaborada.

\section{Participantes}

La población está conformada por 95 participantes; un grupo de 55 personas representa al profesorado; de los cuales 37 son mujeres, equivalente al $67,27 \%$ y 18 son varones, equivalente al $32,73 \%$, véase Figura 21 ; además se tuvo en cuenta los años de experiencia en el sector educativo por lo que se identificó 1 docente con experiencia menor a un año -equivalente al $1,82 \%$ - con experiencia entre 1 a 5 años y con experiencia entre 6 a 10 años, se identificaron a 12 docentes equivalente al $21,82 \%$, y finalmente los docentes que cuentan con una experiencia laboral entre 11 a 20 años y los que tienen más de 21 años de experiencia, representan el $27,27 \%$ de la población equivalente a 15 docentes, véase Figura 22 .

Por otra parte también se consideró el nivel de enseñanza en el que desempeñaban su labor docente, teniendo en cuenta los diversos contextos socioculturales, los rangos se establecieron de la siguiente manera: Nivel de Enseñanza Primaria - Infantil, conformada por 23 docentes -equivalente al 41,82\%-; Nivel de enseñanza Secundaria - ESO - College, conformada por 11 docentes —equivalente al 20\%-; Bachillerato - Lycee, con una población de 6 docentes —equivalente al 10,91\% - y 
Formación Profesional - Enseñanza Superior, conformado por 15 docentes equivalente al $27,27 \%$ - véase Figura 23.

Y los otros 40 participantes representan al grupo de artistas de diversas disciplinas: visual, plásticas, escénicas, musicales, literarias; que estuvo conformada por 23 mujeres —equivalente al $57,50 \%$ - y 17 varones —equivalente al $42,50 \%$-; aquí se tuvo en cuenta el rango de edad que está correlacionado con sus años de experiencia en el sector, por lo que se identificaron 17 artistas que tienen entre 22 a 30 años equivalente al $42,50 \%$ - 13 correspondientes a 31 a 40 años -equivalente al $32,50 \%$ - y 10 con más de 40 años de edad —equivalente al $25 \%$-, véase Figura 24 , respectivamente.

La intencionalidad de tener una muestra de diversos contextos socioculturales - Perú, España, Argentina, México, Francia, Italia, Colombia, Chile - tiene la finalidad de poder tener una serie de perspectivas sobre la enseñanza, la innovación metodológica; y el arte como metodología de enseñanza independientemente del lugar de origen y residencia.

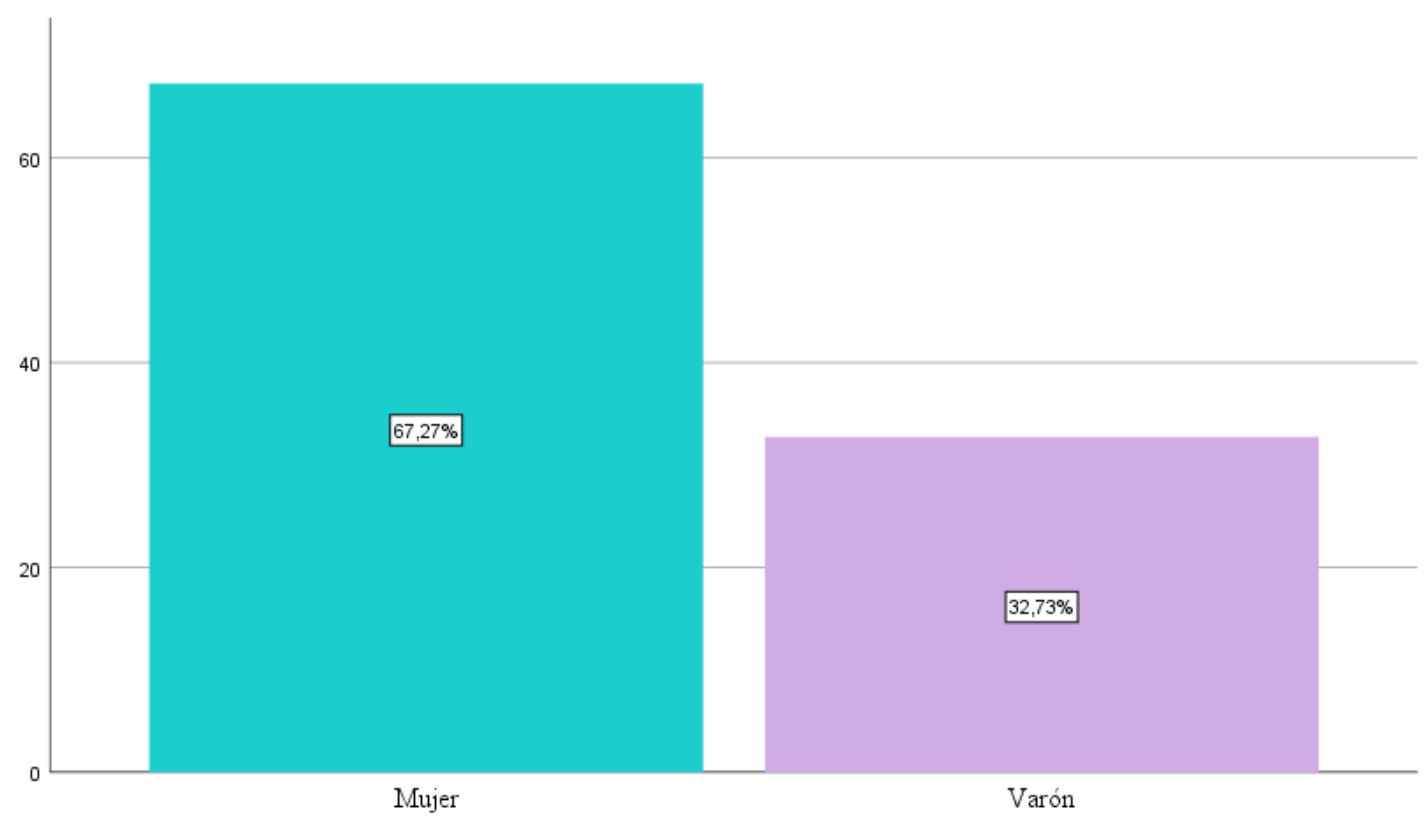

Figura 21: Población de profesorado de acuerdo a su género. Elaboración propia. 


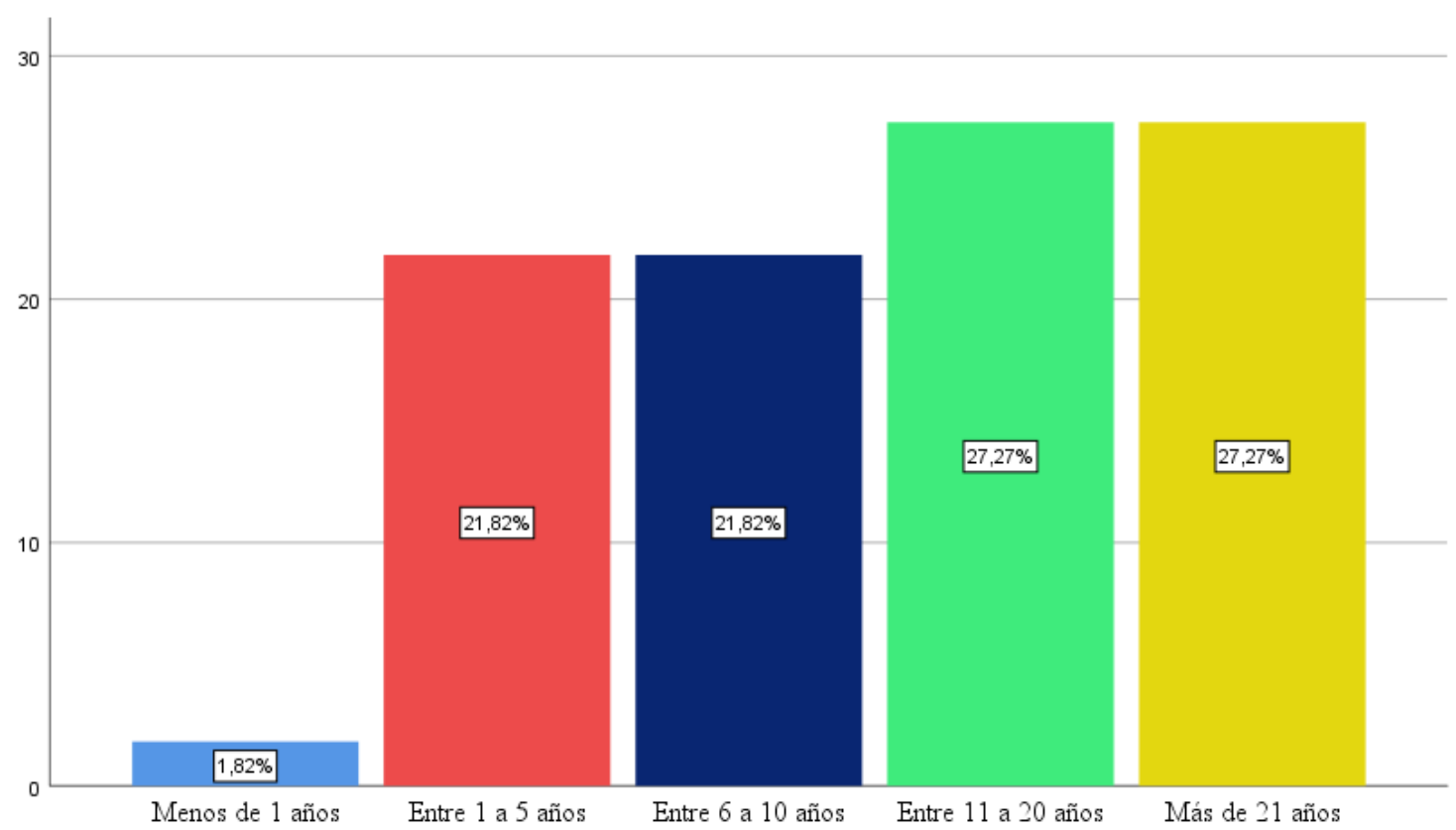

Figura 22: Población de profesorado de acuerdo a los años de experiencia dentro del ámbito educativo. Elaboración propia.

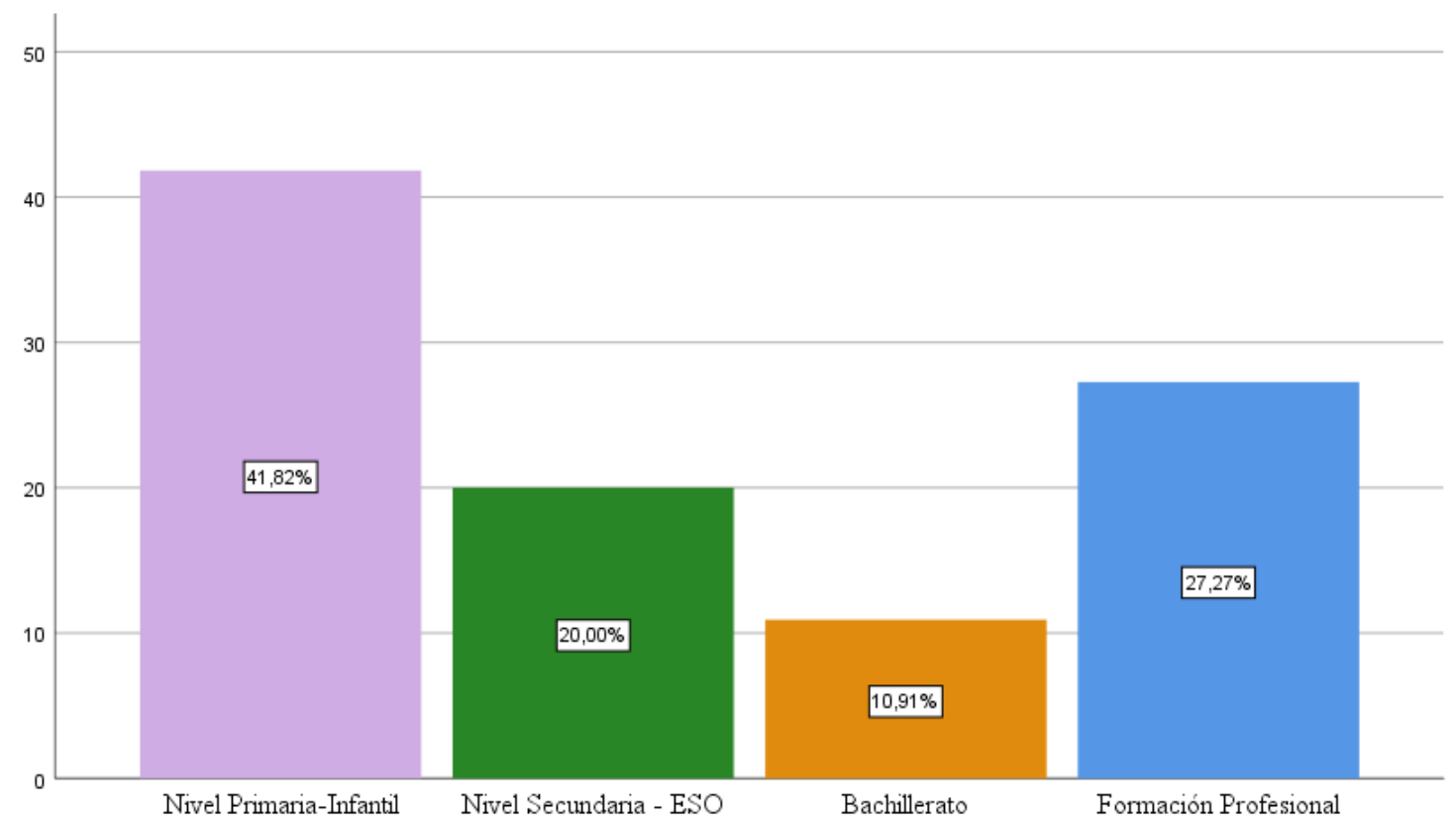

Figura 23: Población de profesorado de acuerdo al nivel de enseñanza que imparte. Elaboración propia. 


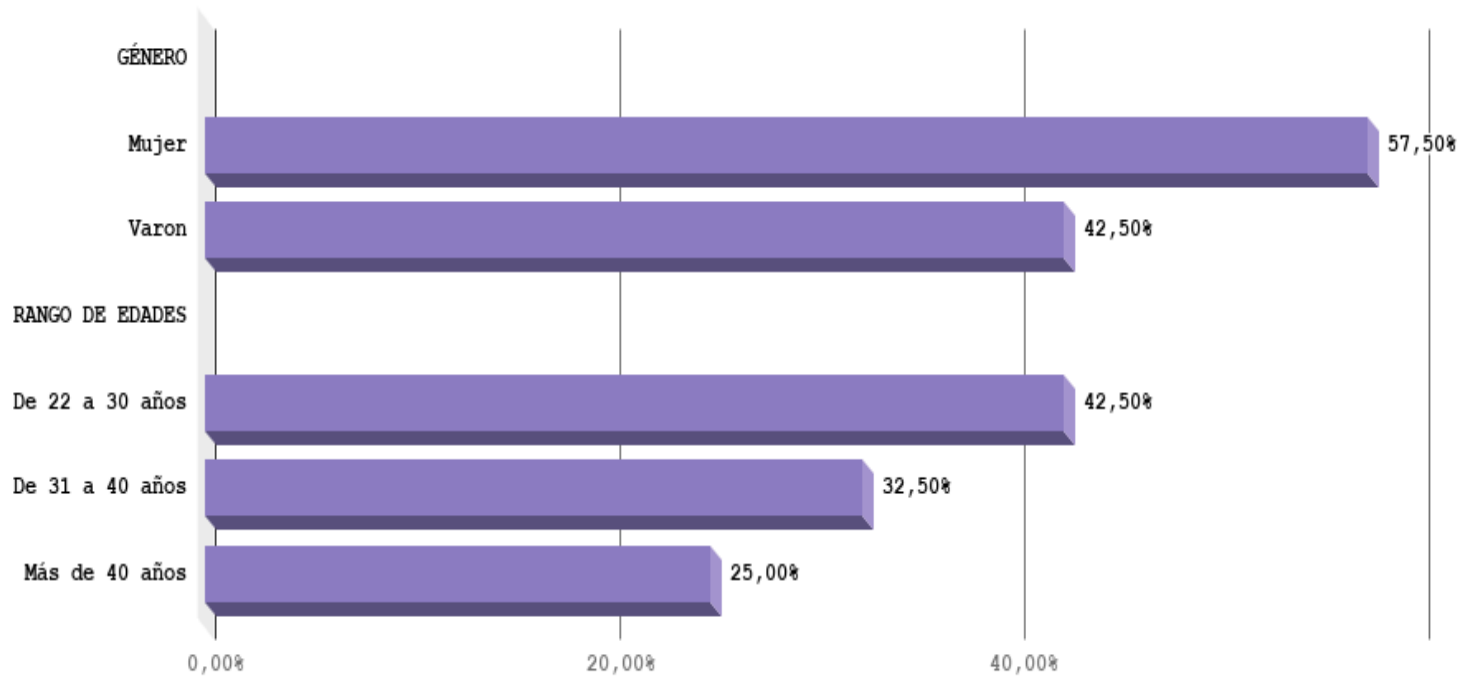

Figura 24: Población de artistas, porcentajes en base a género y rango de edades. Elaboración propia.

\section{Instrumentos}

\section{Cuestionario sobre Enfoques des Enseñanza}

En función de nuestro problema y objetivo general, una de las variables medidas de la investigación se valoró de manera cuantitativa a través de la aplicación del Cuestionario sobre Enfoques de Enseñanza (CEE), elaborado por Trigwell y Prosser en 1999, traducido y adaptado al contexto español por el grupo de investigación dirigido por la profesora Hernández Pina (2010).

EI CEE incluye dieciséis ítems sobre la concepción e intención con la que el profesorado desarrolla su actividad docente, viene acompañado de una escala tipo Likert con cinco valores - del 1 al 5-, para lo que cada participante debe elegir el valor de la escala en función de grado en que se le aplique lo referido en cada pregunta, siendo 1 el valor que representa si el ítem le ocurre nunca o muy raras veces y 5 si lo que se indica le ocurre siempre o casi siempre. Al finalizar cada participante obtiene dos puntuaciones; una referida al Enfoque Basado en la Enseñanza -EBE-, relacionado con el enfoque superficial de aprendizaje establecido; mientras que la puntuación basada en el Enfoque Basado en el Aprendizaje -EBA - está asociado al enfoque profundo de aprendizaje, véase en el Anexo 1 -las versiones en castellano y francés por la diversidad de la poblaciónen la que se apreciará la totalidad del instrumento. Se interpreta que de las dos, la más alta indicaría el enfoque predominante en el profesorado. Así mismo cada escala consta de dos subescalas, por tanto cada participante obtiene cuatro puntuaciones referidas a las intenciones y a las estrategias. La aplicación del instrumento a la muestra participantes, pese al reducido número, ha sido aceptable, ya que el instrumento ha obtenido un índice Alfa de Cronbrach de 0.833 , quedando validada su fiabilidad.

\section{Entrevistas}

Los métodos mediante los cuales estudiamos a las personas necesariamente influyen sobre el modo en que las vemos. Para poder conocer el aspecto humano de los participantes se llevó a cabo una entrevista personal con el profesorado y artistas; teniendo en cuenta que como técnica cualitativa, la entrevista es una de las vías más 
comunes para investigar la realidad porque permite recoger información sobre acontecimientos y aspectos subjetivos de las personas: creencias y actitudes, opiniones, valores o conocimiento, que de otra manera no estarían al alcance del investigador. Se elaboraron una serie de preguntas de carácter abierto, para cada grupo. Con relación al profesorado la finalidad fue conocer sobre su experiencia y trayectoria laboral; así como sus opiniones y apreciaciones sobre la innovación metodológica, y los principales factores que son relevantes para generar un aprendizaje significativo. Respecto a los artistas con la finalidad de conocer también sus experiencias laborales y en especial los principales aportes que ha generado el arte como una herramienta educativa, y su aplicación en el ámbito de la educación formal, véase el Anexo 2, en la que se muestran las preguntas realizadas para ambas poblaciones.

\section{Procedimiento}

El proceso seguido para la recogida de datos queda sintetizada del siguiente modo: tras contactar con instituciones educativas, profesores y artistas que desearon participar, se concertaron diversas fechas para aplicar el Cuestionario de Enfoques de Enseñanza al profesorado - que por temas de distancia algunos fueron realizados vía online, durante el mes de Marzo-se inició explicando la finalidad de la investigación, se continuó explicando el procedimiento de cumplimentación, así como la necesidad de que respondan la totalidad de los ítems con honestidad, el tiempo estimado fue de unos 15 a 20 minutos. Una vez finalizada la aplicación del instrumento se procedió a informatizar las respuestas en la hoja de datos del programa estadístico SPSS versión 17.0 y realizar los análisis correspondientes.

Para complementar los datos obtenidos, se procedió a realizar entrevistas al profesorado participante paralelamente también se llevaron a cabo entrevistas a los artistas; el tiempo estimado fue de aproximadamente 20 minutos por cada entrevista - presencial y vía online- una vez finalizada la recogida de información se realizó un análisis conversacional, "considerada como la línea de investigación de mayor solidez en la etnometodología; puesto que intenta describir y explicar las prácticas colaborativas que los hablantes utilizan y seleccionan cuando ellos establecen una interacción inteligible" (Colás, 1998, p. 245); con el propósito de conocer y describir la interpretación que los docentes y artistas presentan sobre sus prácticas educativas y artísticas correspondientemente.

Una vez realizada la aplicación del cuestionario y las entrevistas al profesorado y artistas; se procedió a enviarles vía correo electrónico el link de la página web elaborada, denominada QENTI —vocablo quechua que significa "portador de buenas noticias- en la que se se da a conocer una propuesta de intervención a las instituciones educativos basado en tres enfoques: Educación, Arte y Neuropsicología, en la que se pretende desarrollar una innovación metodológica que tiene como elemento principal y como marco estratégico de enseñanza $<<$ el uso del Arte>>; a través de: Formaciones personalizadas a los docentes y artistas interesados en educación; y un Programa de Intervención en Aulas contextualizada en base a las necesidades educativas previamente identificadas, véase Figura 25. 


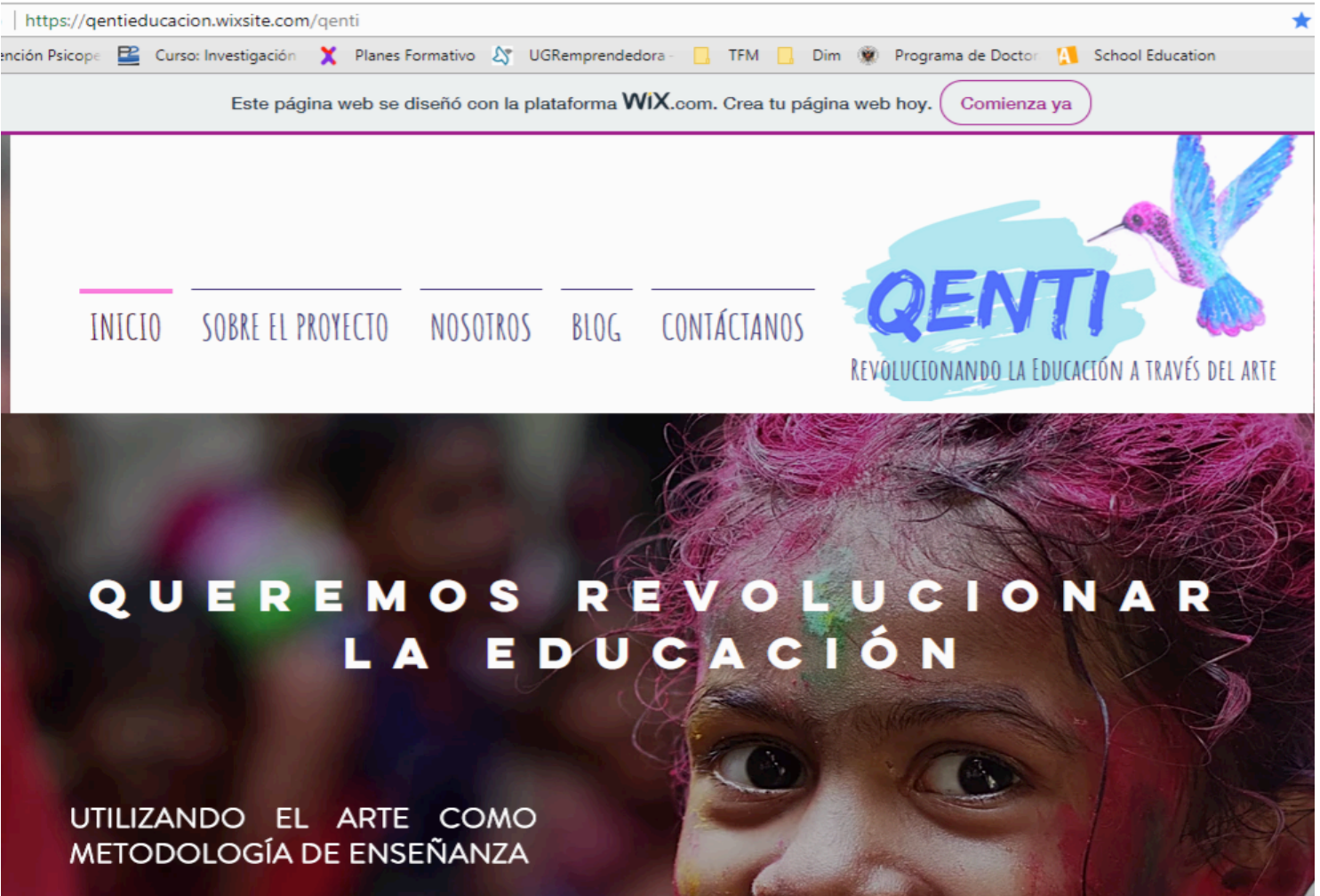

Figura 25: Página web “QENTI”. Elaboración propia.

\section{Análisis de Datos}

Con la utilización del programa estadístico SPSS, se realizaron diversos análisis como: Descriptivos y de Frecuencias, para conocer sobre el Enfoque de Enseñanza predominante en la muestra; y si existen diferencias en la población en base a su género, años de experiencia y nivel de enseñanza que imparten docencia; además se desarrolló el Análisis Correlacional, para verificar la coherencia entre las intenciones y estrategias por cada enfoque de enseñanza y entre enfoques.

Por otra parte, para la información recogida durante las entrevistas a profesores y artistas, se realizó un análisis conversacional, para ello se utilizó el programa Ethnograph —creado por John Seidel-, que se encarga de realizar análisis descriptivo e interpretativos de las entrevistas realizadas, en base a un listado de categorías, elaboradas para cada una de las poblaciones: artistas y profesorado.

Finalmente para conocer el grado de aceptación de los participantes hacia el uso del arte como metodología de enseñanza, se realizó un análisis de frecuencia de visita y suscripción sobre la página web elaborada.

\section{Resultados}

\section{¿Qué opina el profesorado?}

Como respuesta al objetivo principal, se ha realizado un estudio descriptivo, véase la tabla 4, de las dos principales concepciones de enseñanza: Basada en el Aprendizaje -EBA - versus el Enfoque Basado en la Enseñanza -EBE- adoptadas por la población de estudio. Lo que nos da a conocer que, la media más alta corresponde al Enfoque Basado en el Aprendizaje, siendo la diferencia entre ambas de acuerdo a la $t$ de Student significativa. Así mismo podemos observar en la Tabla 3 , que la 
concepción de enseñanza más utilizada por el profesorado es la concepción de enseñanza centrada en el cambio conceptual, con un $89,1 \%$, mientras que sólo el 10,9\% utiliza la concepción centrada en la transmisión de información.

Tabla 3: Estadísticos Descriptivos de los Enfoques de Enseñanza del profesorado

\begin{tabular}{|c|c|c|c|c|c|}
\hline & N & Mínimo & Máximo & Media & $\begin{array}{c}\text { Desv. } \\
\text { Desviación }\end{array}$ \\
\hline EBA & 55 & 24 & 39 & 32,27 & 3,778 \\
EBE & 55 & 12 & 39 & 23,58 & 6,139 \\
$\begin{array}{c}\text { N válido } \\
\text { (por lista) }\end{array}$ & 55 & & & & \\
\hline
\end{tabular}

\begin{tabular}{|c|c|c|c|c|c|}
\hline & & Frecuencia & Porcentaje & $\begin{array}{l}\text { Porcentaje } \\
\text { válido }\end{array}$ & $\begin{array}{l}\text { Porcentaje } \\
\text { acumulado }\end{array}$ \\
\hline Válido & EBE & 6 & 10,9 & 10,9 & 10,9 \\
\hline 1 & EBA & 49 & 89,1 & 89,1 & 100,0 \\
\hline & Total & 55 & 100,0 & 100,0 & \\
\hline
\end{tabular}

Fuente: Resultados obtenidos a través del programa estadístico SSPS.

Estos resultados obtenidos, son reforzados por los datos obtenidos del análisis descriptivo de frecuencia, media y modo, aplicados en las respuestas de la segunda parte de cuestionario; en la que el profesorado debía otorgar una valoración a las afirmaciones planteadas —otorgándoles valores del 1 al 5 , siendo este último de mayor valor- en base a la importancia ellos otorgaban en su práctica docente, como respuesta a "Enseñar es", véase Tabla 4. En la que se puede observar que las medias más altas corresponden a las afirmaciones de: "Promover cambios conceptuales en los estudiantes, el protagonista es el estudiante y el profesor ayuda en el cambio de su visión del mundo. El estudiante debe reconstruir su conocimiento para desarrollar una nueva visión del mundo o nuevas concepciones", con 4,44 y "Promover el desarrollo conceptual en los estudiantes con el de que estos construyan su propio conocimiento y desarrollen sus propias concepciones", con un 4,25; los que su vez guardan correlación con el Enfoque Basado en el cambio conceptual.

Tabla 4: Estadísticos Descriptivos de las Respuestas del profesorado a la pregunta: "Enseñar es.."

\begin{tabular}{|c|c|c|c|c|c|c|}
\hline & & $\begin{array}{l}\text { Transmitir } \\
\text { Información }\end{array}$ & $\begin{array}{l}\text { Conceptos } \\
\text { asignatura }\end{array}$ & $\begin{array}{l}\text { Estrategias } \\
\text { Interactivas }\end{array}$ & $\begin{array}{l}\text { Desarrollo } \\
\text { Conceptual }\end{array}$ & $\begin{array}{c}\text { Cambio } \\
\text { Concep } \\
\text { tual }\end{array}$ \\
\hline \multirow[t]{2}{*}{$\mathbf{N}$} & Válido & 55 & 55 & 55 & 55 & 55 \\
\hline & Perdidos & 0 & 0 & 0 & 0 & 0 \\
\hline
\end{tabular}




\begin{tabular}{|c|c|c|c|c|c|}
\hline Media & 2,82 & 3,18 & 3,85 & 4,25 & 4,44 \\
\hline Moda & 1 & 4 & 5 & 5 & 5 \\
\hline
\end{tabular}

Fuente: Elaboración propia, a través del programa estadístico SSPS.

Para conocer si existen diferencias significativas entre la población en base a su género, experiencia y nivel de enseñanza, se realizó obteniendo que no existen diferencias significativas entre el profesorado con relación al género y años de experiencia; sin embargo si existen diferencias significativas con relación a los enfoques de enseñanza superficial y profundo con relación al nivel de enseñanza al que pertenece el profesorado, especialmente entre los niveles:

- Perteneciente al nivel de enseñanza Primaria y Bachillerato.

- Perteneciente al nivel de enseñanza Primaria y Formación Profesional.

- Perteneciente al nivel de enseñanza Bachillerato y Formación Profesional.

Por otra parte al analizar la coherencia entre intenciones y estrategias dentro de cada enfoque y entre enfoques; se realizó un análisis de correlación de Pearson. Cabe mencionar que la teoría señala que debe haber una coherencia entre intenciones y estrategias dentro de cada enfoque; que entre las intenciones y estrategias con enfoques opuestos (Hernández Pina, et. al 2012), véase Figura 26.

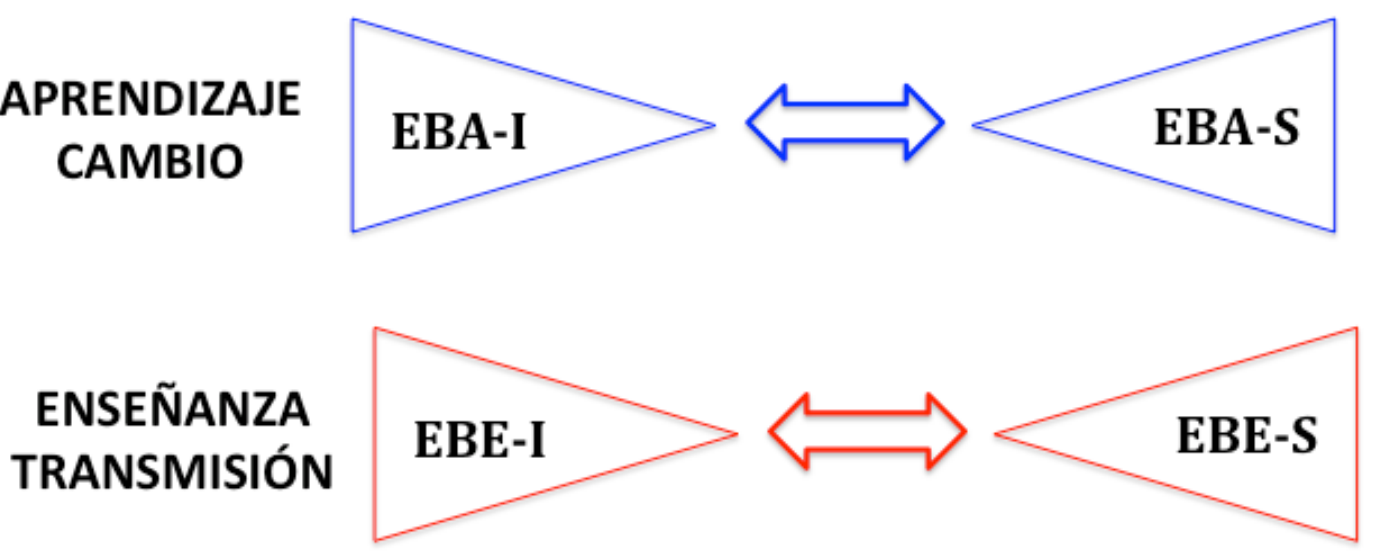

Figura 26: Modelo de coherencia entre intenciones y estrategias. Elaborado por Hernández - Pina, F., Maquilón, J. y Monroy, F. (2012, p. 72)

Sin embargo luego de haber realizado las correlaciones entre las cuatro subescalas; observamos que la correlación significativa entre las subescalas dentro de un mismo enfoque, centrado en el aprendizaje (EBA-I y EBA-S) $.27^{*}$ y centrado en la enseñanza (EBE-I y EBE-S) $.696^{* *}$, siendo más coherente la segunda escala. Igualmente se identificó que la correlación entre las intenciones del enfoque centrado en el estudiante (EBA-I) con las estrategias del enfoque centrado en la enseñanza (EBA-S) 1.34, el más alto de todos los coeficientes. El profesorado muestra una intención centrada en el cambio conceptual (EBA-I) pero no duda en recurrir a estrategias que tienen que ver más con la transmisión de la información (EBA-S). Quizás las correlaciones significativas que se producen entre las estrategias (EBE-S y EBA-S) equivalente a .40 y las intenciones (EBE-I y EBA-I) igual a .35 entre los enfoques pueden otorgar una explicación, como podemos ver en la Figura 27. Estos resultados vienen corroborados con la correlación entre ambos enfoques de .96 con una significancia bilateral de .486 . 


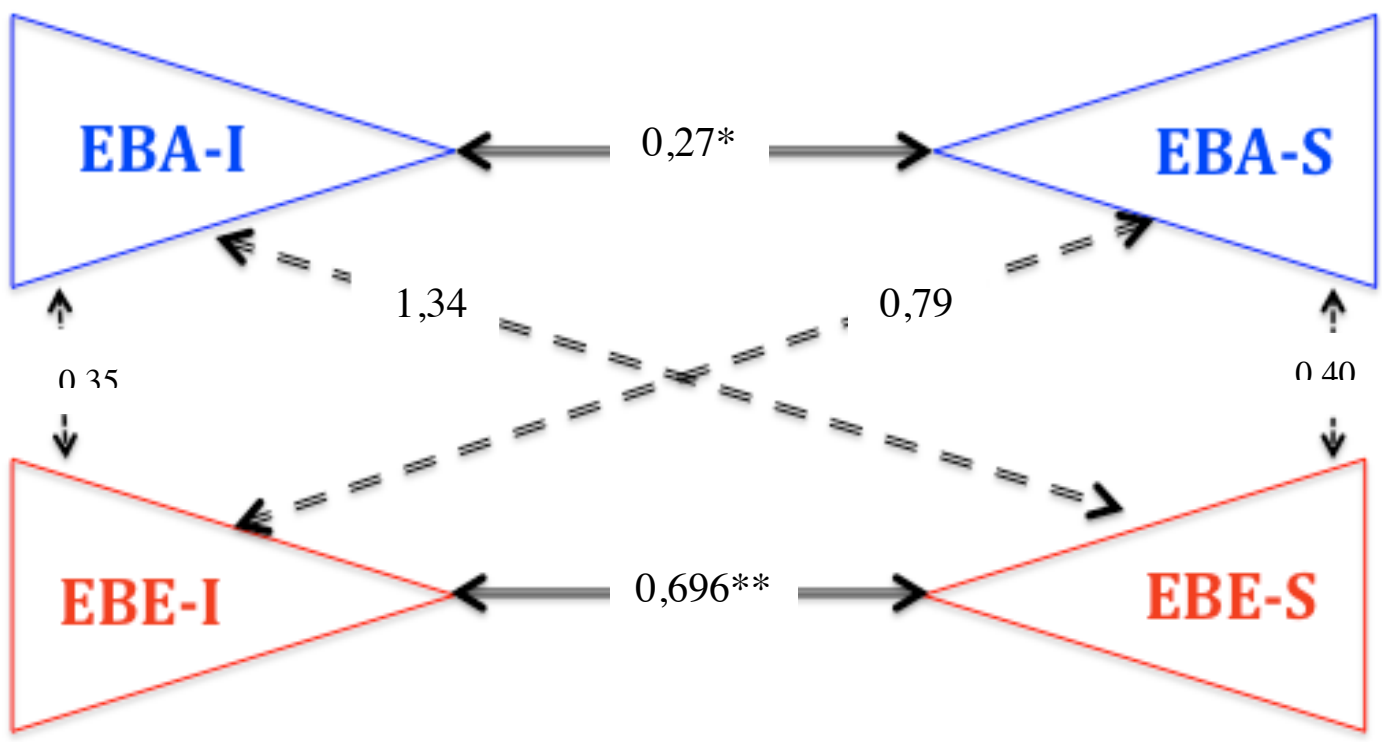

Figura 27: Consistencia de las subescalas de los enfoques de enseñanza obtenidos como resultado de la aplicación del programa estadístico SSPS.

Lo que manifiesta que no existe una concepción claramente definida de lo que implica poner en práctica el enfoque de enseñanza basado en el aprendizaje. Por lo que no se puede identificar si este enfoque propicia una actitud de mayor aceptación a la innovación en metodología de enseñanza; debido a la disparidad entre las intenciones y estrategias.

Luego de haber realizado el análisis cuantitativo, y con la finalidad de enriquecer la discusión de los datos obtenidos, se llevó a cabo un análisis de carácter cualitativo que se realizó a la misma población en base a las entrevistas realizadas; que hacen referencia a las concepciones que presenta el profesorado sobre su práctica docente; para lo cual se realizó un análisis conversacional - propio de la etnometodología que se basa en los procesos de interpretación del discurso- utilizando el programa Ethnograph, en base a un listado de categorías, en función de los testimonios recopilados se obtuvieron las siguientes:

- C1: Generar un descubrimiento y construcción del conocimiento

- C2: Tener en cuenta los Sílabos y contenidos

- C3: Considerar los saberes previos sólidos.

- C4: Aplicar nuevas metodologías en la enseñanza.

- C5: Complementariedad entre las diversas asignaturas.

- C6: Docente refleje una pasión por enseñar, porque generará una pasión para aprender.

- C7: Contextualizada a los intereses y habilidades de los estudiantes, para generar un formación de carácter personal y social.

Cabe mencionar que las categorías: C1, C3 y C7 guardan relación con el Enfoque Basado en el Aprendizaje debido a su tendencia a considerar aspectos relacionados con el estudiante; mientras que las categorías: C2, C4, C5 y C6 al Enfoque Basado en la Enseñanza puesto que están orientados a los docentes.

Los resultados obtenidos reflejan las intenciones del profesorado para desempeñar una adecuada práctica dentro del ámbito escolar, por lo que luego de obtener el conteo de códigos y convertirlos en porcentajes correspondientes al total de la población, se evidencia que la categoría con mayor porcentaje obtenido es la C1 con un $29,4 \%$, seguidamente de C7 con un $24,7 \%$ de manifestación y C2 con un $17,6 \%$. Para las categoría C4 y C6 comparten un valor del $8,2 \%$. Mientras que los porcentajes 
más bajos, equivalente a un 5,9\% lo obtuvieron las categorías C3 y C5, véase Figura 28.
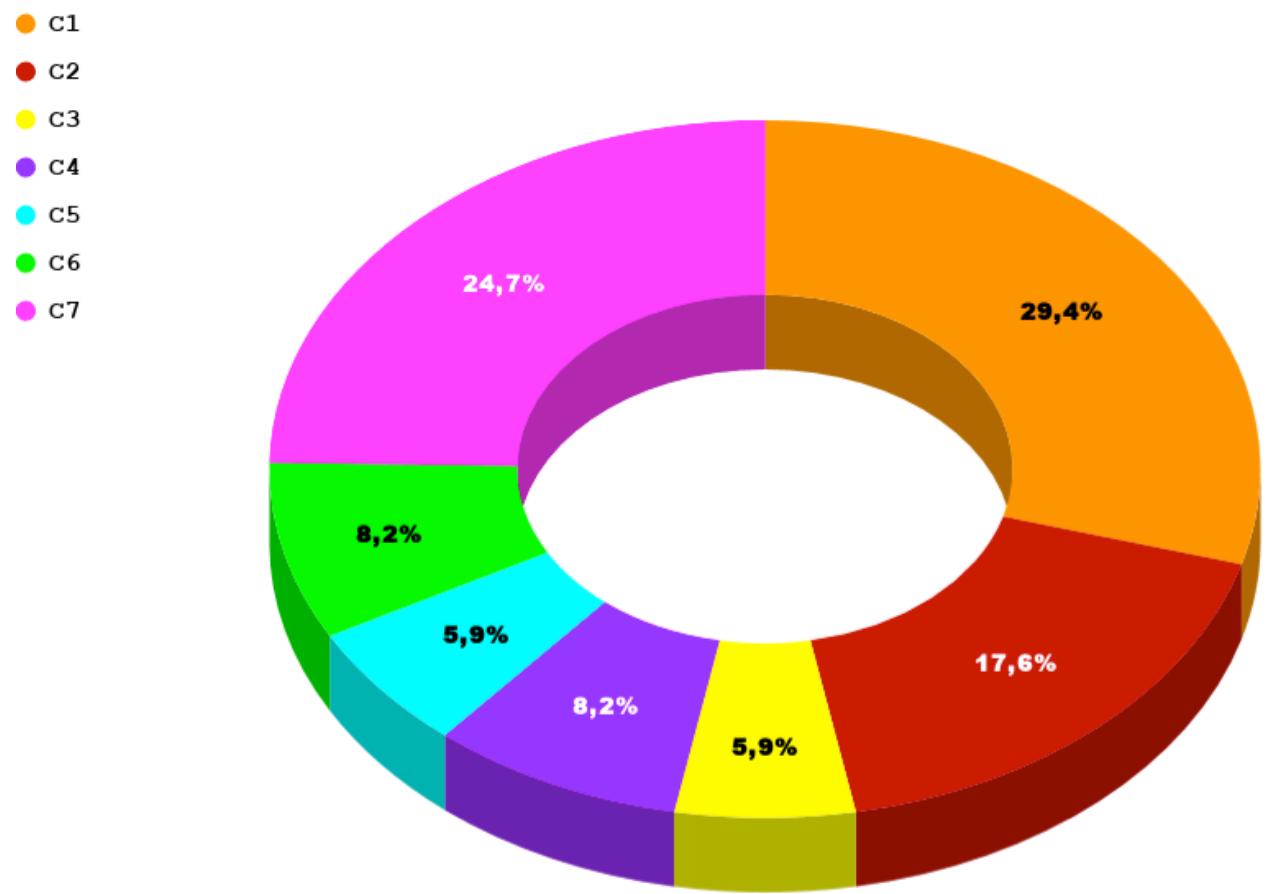

Figura 28: Testimonios del profesorado sobre los factores importantes durante el proceso de enseñanza - aprendizaje. Elaboración propia.

Cómo vemos las categorías con mayor porcentaje corresponden al enfoque basado en el aprendizaje, dando a conocer unas vez más que las intenciones del profesorado están orientados a generar un cambio conceptual en el estudiante; sin embargo la siguiente categoría con mayor relevancia para el profesorado hace referencia al C2: Tener en cuenta los Sílabos y contenidos, que está orientado al Enfoque orientado a la Enseñanza y al mismo tiempo el bajo porcentaje otorgado a las categorías C4: Aplicar nuevas metodologías en la enseñanza, C5: Complementariedad entre las diversas asignaturas y C6: Docente refleja una pasión por enseñar, porque generará una pasión para aprender; podrían ser factores influyentes para que no se logre dar la correlación esperada entre intención y estrategia dentro de cada enfoque de enseñanza, anteriormente correlacionados.

\section{¿Qué opinan los artistas?}

Continuando con este análisis pero esta vez enfocado en los testimonios de los artistas, en la que se estudia la concepción de estos sobre el impacto que tiene el uso del arte como metodología de enseñanza en la educación formal, del mismo modo en base a una serie de categorías obtenidas de las entrevistas realizadas:

- D1: Fortalecer la gestión emocional: Ayudando a conocer y regular las emociones.

- D2: Fortalece la autonomía: A través del autoaprendizaje de las capacidades y habilidades.

- D3: Fomenta la adaptación al cambio.

- D4: Fortalece la creatividad.

- D5: Facilita la capacidad comunicativa - libertad para expresarse. 
- D6: Fortalece las relaciones interpersonales y propicia una mayor conexión con su entorno.

En la que consideran que el mayor impacto del arte como metodología de enseñanza dentro de la educación formal es, siendo las categorías con mayor porcentaje de representatividad son D1 con un $27,8 \%$ y D4 con un $22,5 \%$ de manifestación y aprobación. Seguido de las categorías D5 con un 18,5\%; D6 con un 14,8\% y con $13 \%$ la categoría D2. El porcentaje más bajo es para la categoría D3 con un $3,7 \%$ de manifestación; véase Figura 29.

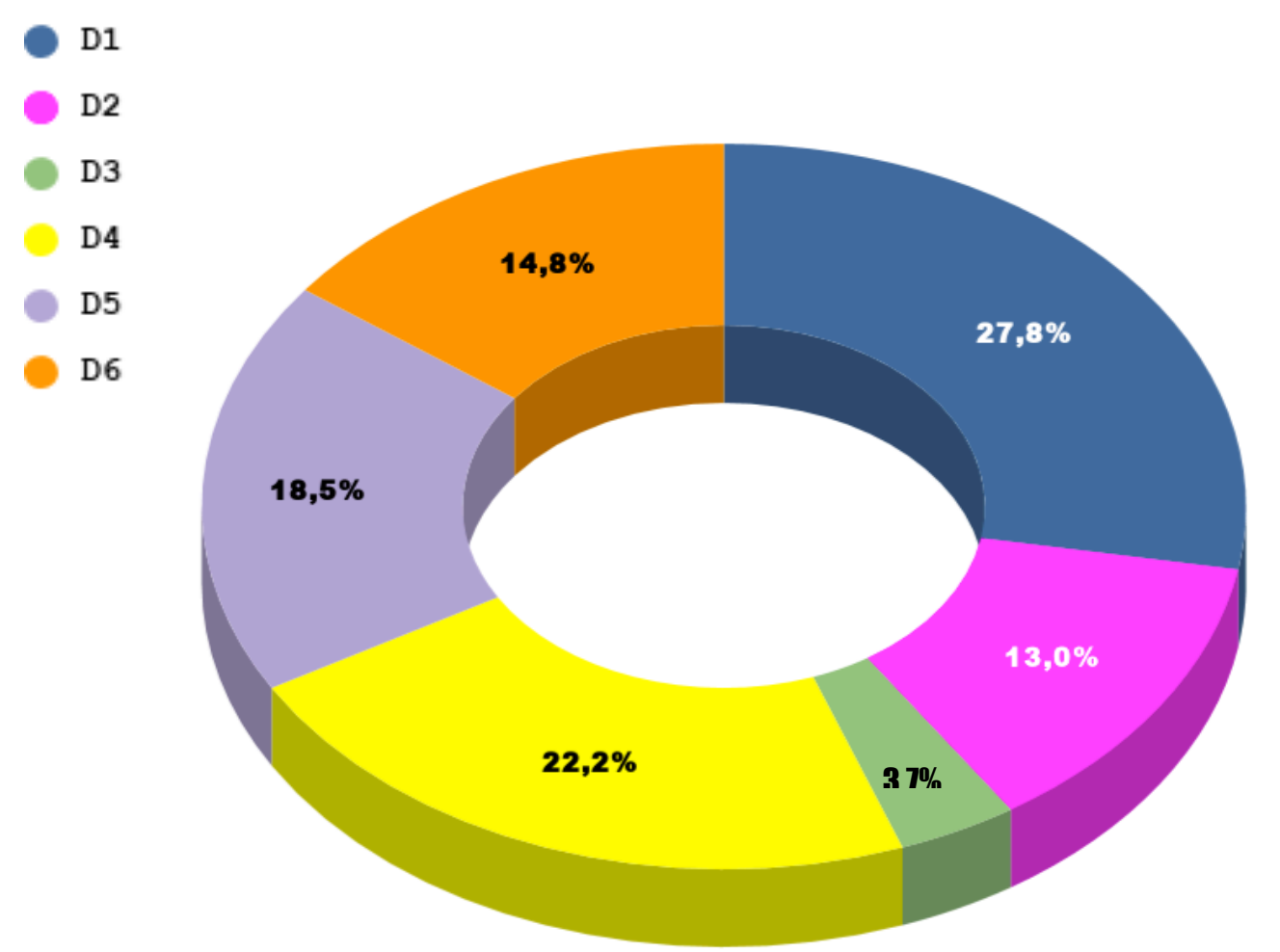

Figura 29: Testimonios de artistas profesorado sobre el impacto del uso del arte como metodología de enseñanza en la educación formal. Elaboración propia.

\section{¿Qué nos dice la Web?}

En base al análisis de frecuencia realizado de la página web elaborada —en un margen de dos meses: Abril y Mayo- se obtuvo un total 119 visitas y 104 suscripciones, lo que refleja un nivel de aceptación significativo, véase Figura 30. 


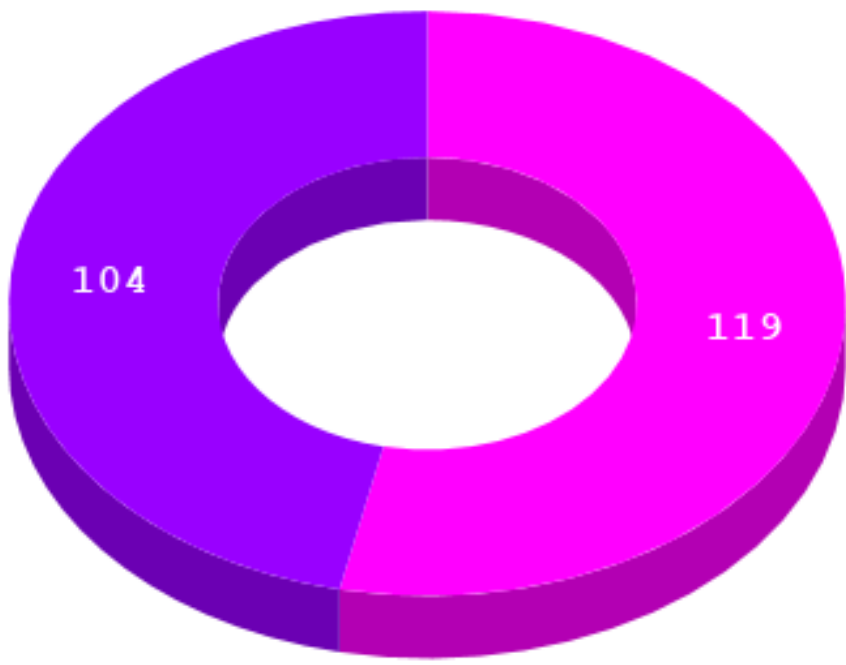

$\mathrm{N}^{\mathrm{a}}$ de visitas

$\mathrm{N}^{\mathrm{a}}$ de subcripciones

Figura 30: Análisis de frecuencia sobre la página web. Elaboración propia

\section{Discusión}

Como hemos sido testigos a lo largo de la evolución del sistema educativo, este viene siendo condicionado por diversos factores especialmente los de índole socioeconómica; esto se ha podido evidenciar en los resultados que hemos obtenido sobre los Enfoques de Enseñanza, puesto que como lo menciona Hernández Pina et. al (2012) "las intenciones del profesor pueden ser unas y las estrategias demandas por el contexto pueden ser diferentes" (p. 73). Cabe mencionar que la diversidad de los contextos socioeducativos que se representan en la población; evidencia que las concepciones sobre la enseñanza están orientados a generar un aprendizaje significativo en los estudiantes - considerando a la enseñanza como una construcción del conocimiento- , sin embargo las intenciones que se aplican en la práctica está orientado a la transmisión de la información, centrándose en los contenidos y sílabos de las materias y en la que el estudiante asume una actitud pasiva; mientras que el profesorado se convierte en el protagonista principal del proceso, Trigwell; Prosser y Taylor en 1994 (citado por Hernández Pina, et. al, 2012). Reflejando una disparidad entre concepciones y estrategias, demandadas por el contexto institucional; considerando el modelo 3P de enseñanza y aprendizaje de Biggs, en la que se considera importante la presencia del Contexto, esto puede generar un impacto desfavorable y confuso en el proceso de aprendizaje de los estudiantes.

En base a ello no se puede identificar si realmente el enfoque de enseñanza profundo asumido por el profesorado propicia una actitud de mayor aceptación a la innovación en metodología de enseñanza; porque no lo vienen desarrollando de manera adecuada, debido a la disparidad identificada anteriormente. Por ello es importante asumir nuevos enfoques y estrategias metodológicas por parte del profesorado para que realmente logren poner en práctica sus intenciones de "lograr aprendizajes significativos".

No podemos dejar de lado el contexto educativo - cultura institucional, demandas gubernamentales, evaluaciones estandarizadas,estándares de calidad educativa, etcétera- que podrían ser los factores influyentes para que las concepciones no 
logren convertirse en estrategias aplicadas durante el proceso de enseñanza aprendizaje, un factor importante dentro del contexto socioeducativo es la convivencia que existe entre el profesorado puesto que se espera que sea favorable para poder generar prácticas metodológicas e implementaciones pedagógicas que sean coherente y congruentes que favorezcan el proceso de aprendizaje de los estudiantes; sin embargo en base a los resultados obtenidos se evidencia que existen diferencias significativas en el profesorado con relación al nivel de enseñanza adoptado por docentes de nivel primaria, Bachillerato y Formación Profesional; el cual puede llegar a considerarse como un factor influyente en la disparidad encontrada entre los enfoques de enseñanza.

Por lo que se propone desde la interacción profesorado y estudiantes, se comience a reestructurar las concepciones sobre el proceso de enseñanza - aprendizaje, considerándolo como un proceso permanente, integrador y orgánico, que involucra la participación e implicación no sólo de los estudiantes, sino también de otros docentes, familias y equipos directivos; y que responda necesariamente a las necesidades educativas, contextualizada a las demandas, inquietudes, motivaciones e intereses de los estudiantes y profesorado; para generar una mayor empatía al momento de aprender y generar la <<pasión por aprender>> y no continuar como una respuesta automática a obtener un mérito externo.

Como Robinson (2016) lo menciona se debe otorgar importancia a fomentar entre los estudiantes <<pasión por aprender>> y para ello es necesario generar una transformación cultural, que parte de las creencias, por asumir el proceso de enseñanza . aprendizaje como una preparación de los estudiantes para afrontar los diversos acontecimientos de su vida y hacer frente a los desafíos que puedan tener, que se refleja en su inteligencia práctica; brindándoles competencias y habilidades mentales, emocionales y sociales, dejando de lado la creencia de que el contenido y los sílabos son irrevocables y asumir una práctica dinámica que involucre a los diversos agentes educativos y a la propia sociedad. Así mismo también se menciona que es de suma importancia ayudar a los estudiantes a descubrir su vocación y en base a ello potenciar las habilidades y competencias correspondientes; lo que ayudará a promover y fortalecer la gestión emocional en los estudiantes.

Los testimonios del profesorado en base al análisis cualitativo realizado, reflejan un mayor porcentaje -a las categorías $\mathrm{C} 1$ y $\mathrm{C} 7$ - consideran que para lograr un aprendizaje significativo en los estudiantes se necesita: Generar un descubrimiento y construcción del conocimiento; además de estar Contextualizadas a los intereses y habilidades de los estudiantes, para generar un formación de carácter personal y social; y ello se logra a través de una metodología de enseñanza en la que el profesorado asuma un rol de acompañante brindando herramientas y estrategias que permita a los estudiantes lograr la apropiación y empoderamiento en su proceso de aprendizaje, en la que además se permita la actuación de los otros agentes de la comunidad educativa; y por ello se considera al ARTE como una estrategia integradora frente a las necesidades educativas.

Y ello se refleja en a los testimonios de artistas que como respuesta al objetivo final sobre la importancia del uso del Arte como una metodología de enseñanza innovadora, se evidencia que tiene un efecto positivo para el desarrollo de competencias como: Creatividad, puesto que los estudiantes asumen una actitud activa como creadores, en la que aumenta su propio reconocimiento y valor hacia sí mismos; lo que repercutirá en sus interacciones interpersonales (Parra, 2016); Relaciones interpersonales y propicia una mayor conexión con su entorno y Habilidades de Comunicación; porque al permitir la libre expresión a través de: pintura, música, escultura, poesía, performance, etcétera, el estudiante es capaz de reconocer 
en sí mismo y conocer en el otro los sentimientos y emociones, generando una interacción interpersonal empática y reflexiva. Durante este proceso de creación también se desarrolla el Autoaprendizaje, en el que durante el proceso de enseñanza - aprendizaje, el estudiante va siendo consciente e identificando sus habilidades y capacidades, lo que ayudará en la consolidación de su autoconcepto; y como menciona Tranche (1995) un individuo con un autoconcepto positivo tiene la capacidad de actuar de manera independiente - participación autónoma- , es capaz de tomar decisiones y asumir una participación activa dentro de la sociedad - participación ciudadana- a través de un análisis y valoración de los diversas realidades. Todo ello se convertirá en instrumentos fundamentales para combatir los prejuicios y estereotipos posibilitando la convivencia basados en el respeto e igualdad.

Las limitaciones que se encontraron en el presente estudio es el número reducido de participantes, provocando que no se puedan generalizar los resultados; por ello se invita y pretende continuar con investigaciones con un mayor número, enfocadas en las metodologías de enseñanza, con la finalidad de fomentar el enfoque basado en el aprendizaje, la coherencia entre intención y estrategia y la actitud de aceptación frente a la innovación metodológica teniendo como elemento principal el uso del arte.

Se considera de suma importancia profundizar en las estrategias de enseñanza que adopta el profesorado de los diversos contextos socioculturales porque son los agentes de la educación que asumen un rol activo y que influye directamente - debido a la convivencia e interacción diaria- en las percepciones sobre el aprendizaje de los estudiantes, quiénes pertenecen a las distintas sociedades, que a su vez requieren de personas que sean más conscientes de sus acciones e interacciones con los demás, y con su cultura; con la intención de poder generar un bienestar y felicidad.

\section{Referencias}

Acaso, M.y Megías, C. (2017). Art Thinking: cómo el arte puede transformar la educación. Barcelona: Paidós.

Banco Mundial (2016). Gasto Público en Educación. Instituto de Estadística de la Organización de las Naciones Unidas para la Educación, la Ciencia y la Cultura. (Archived by WebCite ${ }^{\circledR}$ at http://www.webcitation.org/6zL18hdM4)

BID (2013). La Economía Naranja. Bogotá: PuntoaparteBookvertising.

Biggs, J. (2015). Calidad Del Aprendizaje Universitario. Madrid: Narcea.

Bona, C. (2016). La Nueva educación: Los Retos y desafíos De Un Maestro De Hoy. Madrid:Plaza Janés.

Brito, Z. (2008). Cap. 2: Educación Popular, Cultura e Identidad desde la Perspectiva de Paulo Freire. En Gadotti, M., Gomez, M., Mafra, J. y Fernandes, A. (Eds). Contribuciones para la Pedagogía. (29 - 45) Buenos Aires:CLACSO.

Cárdenas, F., Hernández - Pina, F., Monroy, F. y Soler, M. (2017). Enfoques de aprendizaje y enfoques de enseñanza: origen y evolución. Educación y Educadores. (Archived by WebCite® at http://www.webcitation.org/6zMh3o2Wq)

Chomsky, N. (2012). La (Des) educación. Barcelona: Crítica.

Colás, Ma.P. (1998). Cap. 7: Enfoques en la Metodología cualitativa: sus prácticas de investigación. En Buendía, L., Colás, Ma.P. y Hernández - Pina, F. (Eds.), Métodos de Investigación en Psicopedagogía. (226 - 249) Madrid: McGraw Hill.

Coleman, Liz (2009). A Call to Reinvent Liberal Arts Education. (Archived by WebCite $\circledast$ at http://www.webcitation.org/6zMse0Rm3)

Díaz, M. (2017). ¿Por Qué Educamos? - Conversaciones con Expertos. Madrid: LID.

Flecha, R. \& Tortajada, I. (2005). Cap. 1: Retos y salidas educativas en la entrada del siglo. En Imbernón, F.rancesc \& Bartolomé, L. (Eds.), La educación En El Siglo XXI: Los
Retos Del Futuro Inmediato. (4 - 13) Barcelona: Graó.

Fonseca, A. (2008). Economía Creativa - como estrategia de desarrollo: una visión de los países en desarrollo. Sao Paulo: Centro de Documentação e Referência Itaú Cultural.

Freire, P. (1987). Educación y Cambio. Buenos Aires: Búsqueda.

Freire, P. (1999). Educação como prática da liberdade. Río de Janeiro: Paz e Terra.

Freire, J. (2017). El futuro de la Educación: Aprender lo que no pueden hacer las máquinas. (Archived by WebCite ${ }^{\circledR}$ at http://www.webcitation.org/6zMyE5bN5)

Garbulsky, J. (2017). Zombies en la Escuela. (Archived by WebCite $\circledast$ at http://www.webcitation.org/6zMe40tps)

Giddens, A. (1995). Modernidad e identidad del yo. Barcelona: Península.

Gimeno, J. (2005). Cap. 2: La educación que tenemos, la educación que queremos. En Imbernón, F.rancesc \& Bartolomé, L. (Eds.), La educación En El Siglo XXI: Los Retos Del Futuro Inmediato. (15 - 31) Barcelona: Graó.

Gonzalo, N. (2012). La Educación Artística y el Arte como Terapia: un camino para construir la Identidad del Adolescente. (Archived by WebCite ${ }^{\circledR}$ at http://www.webcitation.org/6zMuglcrt)

Hernández - Pina, F. y Maquilón, J. (2010). Las concepciones de la enseñanza. Aportaciones para la formación del profesorado. (Archived by WebCite ${ }^{\circ}$ at http://www.webcitation.org/6zbVF7ZfD)

Hernández - Pina, F., Maquilón, J. y Monroy, F. (2012). Estudio de los Enfoques de Enseñanza en Profesorado de Educación Primaria (Archived by WebCite ${ }^{\circledR}$ at http://www.webcitation.org/6zMmluofR)

Imbernón, F. \& Bartolomé, L. (2005) La educación En El Siglo XXI: Los Retos Del Futuro Inmediato. Barcelona: Graó. 
International Indigenous People's Forum on Climate Change (2015). Conocimientos ancestrales de los pueblos indigenas, como apuesta para enfrentar el cambio climático. (Archived by WebCite ${ }^{\circledR}$ at http://www.webcitation.org/6zQtTC04h)

Kleinbaum, N. (1997). El club de los poetas muertos. Barcelona: Cercle de Lectors.

Lam, B. \& Kember, D. (2006). The relationship between conceptions of teaching and approaches to teaching. Teachers and Teaching: Theory and Practice. (Archived by WebCite $®$ at http://www.webcitation.org/6zMdMxbaD)

López, M. y Martínez, N. (2006). Arteterapia. Conocimiento interior a través de la expresión artística. Madrid: Ediciones Tutor S.A.

Meirieu, P. (2008). Frankenstein Educador. Barcelona: Laertes.

Monroy, F. (2013) Enfoques de Enseñanza y de Aprendizaje de los estudiantes del Máster Universitario en Formación de Profesorado de Educación Secundaria. (Archived by WebCite $₫$ at http://www.webcitation.org/6zMTHoxFC)

Mora, F. (2016). Neuroeducación: solo se puede aprender aquello que se ama. Madrid: Alianza Editorial

OECD (2005). La cuestión del profesorado: atraer, capacitar y conservar a profesores eficientes. Paris: OECD Publishing.

OECD (2015), Education Policy Outlook 2015: Making Reforms Happen, Paris: OECD Publishing.

OECD (2016), PISA 2015: Results (Volume I): Excellence and Equity in Education, Paris: OECD Publishing.

OECD (2016) Panorama de la Sociedad 2016: OECD Indicadores Sociales. (Archived by WebCite $\AA$ at http://www.webcitation.org/6zMftw6Bk)

Parra, M. (2016). La Creatividad En La Educación Infantil De Las
Instituciones Educativas Públicas y Privadas De La Ciudad De Bucaramanga. (Archived by WebCite $\AA$ at http://www.webcitation.org/6zMxtSdku)

PNUD (2014). Informe sobre la Economía Creativa. México:Copyright (C) Naciones Unidas

Ramos, F. y López, L. (2013). Ciudades Educadoras y Ciudades Creativas, Las Nuevas Fórmulas De La Pedagogía Social En El Siglo XXI.(Archived by WebCite ${ }^{\circledR}$ at http://www.webcitation.org/6zPLGgJAC)

Robinson, K. (2011). Out of Our Minds: Learning to Be Creative. United Kingdom:Capstone Publishing.

Robinson, K. y Aronica, L. (2016). Escuelas creativas: la revolución que está transformando la educación. Barcelona: Penguin Random House.

Tranche, J. L (1995). Potenciando el Autoconcepto. Cuadernos de Pedagogía, 241, 45 - 47

UNESCO (2005). Objetivos principales para apoyar los ODS 2030 (Archived by WebCite ${ }$ at http://www.webcitation.org/6zMQm6Bns)

UNESCO (2015). Declaración de Qingdao 2017: Estrategias de movilización de las TIC para realizar la agenda 2030. (Archived by WebCite ${ }^{\circledR}$ at http://www.webcitation.org/6zMpV9FQq)

UNESCO (2017). Ciudades creativas (Archived by WebCite® at http://www.webcitation.org/6zMPtz6RK)

World Economic Forum (2016). Top ten skills you need. (Archived by WebCite ${ }^{\circledR}$ at http://www.webcitation.org/6zKwPpako)

Zabalza - Beraza, M. y Zabalza - Cerdeiriña, A. (2012). Planificación de la Docencia en la Universidad. Madrid: Narcea.

\section{Anexos}

\section{ENTREVISTA A PROFESORADO}

\section{PREGUNTAS ORIENTATIVAS}

¿Hace cuánto tiempo se dedica a la educación? ¿Qué lo motiva en su día a día como docente?

¿Cual de los dos enfoques de enseñanza es más importante: "la transmisión de conocimientos" o "el cambio conceptual en los estudiantes"? ¿Por qué?

¿Considera que la institución para la que trabaja lo ayuda a ser un profesional más competente, de qué manera?

¿Se encuentra a favor o en contra de las nuevas e innovadoras metodologías de enseñanza? ¿Ha escuchado sobre Art Thinking? Luego de esta breve descripción ¿Qué opina al respecto?

ART THINKING: pretende posicionar las artes visuales como metodología para cualquier tipo de aprendizaje, es decir, es una macro metodología educativa que introduce las artes visuales, escénicas, digitales, literarias y la arquitectura no como contenidos sino como maneras de hacer en los contextos educativos: la escuela, los museos, la universidad y nuestras casas. Así mismo pretende empoderar a los educadores como los productores culturales y los intelectuales transformativos en la sociedad.

¿Ha escuchado hablar sobre la Economía Naranja?. Luego de esta breve descripción ¿Qué opina al respecto?

ECONOMÍA NARANJA, conocida también como "Economía Creativa", y se le otorga este nombre al grupo de actividades a través de las cuales las ideas se transforman en bienes y servicios culturales y creativos. Se le reconoce cada vez más como un importante motor del desarrollo económico. 
Luego de conocer un poco más sobre esta nueva economía que ya se viene trabajando en países como estados unidos, e iniciando proyectos en latinoamérica. Y propuesta educativas como el Art Thinking. ¿Considera que la labor del docente debe adaptarse y fomentar el pensamiento creativo en las aulas?

\section{ENTREVISTA A ARTISTAS}

\section{Datos Sociodemográficos:}

- Género:

- Edad:

- Años de experiencia en el ámbito artístico:

\section{PREGUNTAS ORIENTATIVAS}

¿Cuál es la relación que tiene con el mundo artístico, es decir: espectador, crítico del arte, artista, gestión de proyectos artísticos, etc.? En base a ello: ¿Qué es el ARTE para Ud.?

¿Desde qué edad se considera apropiado el contacto con el arte? ¿Por qué?

¿Considera que el arte es una disciplina que regula múltiples habilidades y destrezas comparado a otras disciplinas? ¿Por qué?

¿Qué tan productivo considera que es la aplicación del arte como metodología de enseñanza? ¿Lo ha aplicado en su desempeño profesional de qué manera?

¿Considera que los docentes son capaces de poder aplicar en su praxis una metodología distinta a la tradicional? ¿Podría ud. como artista estar dispuesto a brindar soporte?

¿Ha escuchado hablar sobre la Economía Naranja?. Luego de esta breve descripción ¿Qué opina al respecto?

ECONOMÍA NARANJA, conocida también como "Economía Creativa", y se le otorga este nombre al grupo de actividades a través de las cuales las ideas se transforman en bienes y servicios culturales y creativos. Se le reconoce cada vez más como un importante motor del desarrollo económico.

Luego de conocer un poco más sobre esta nueva economía que ya se viene trabajando en países como estados unidos, e iniciando proyectos en latinoamérica. ¿Considera que la labor del artista debe adaptarse y tener más participación en el ámbito educativo formal? 